śrīgaṇeśāya namaḥ | atha tanvādidvādaśabhāvavicārādhyāyah | uktaṃ ca yādavena |

bhāvaṃ parasyānadhigamya dhīmān

nește 'pi vaktum sa hitāhitam kșamah |

tathaiva tanvādikabhāvajātam

śubhāśubham tadviṿ̛nomyathāham \|

dvādaśabhāvānāṃ saṃjñāḥ samarasiṃhenoktāḥ |

tanudhanasahajasuhṛtsutaripujāyāmrtyudharmakarmāyāḥ |

vyaya iti bhāvā dvādaśa kāryasthānāni lagnādyāḥ || iti ||

atha sāmānyato bhāvavicāra ukto 'bdatantre |

yo bhāvaḥ svāmisaumyābhyām dṛ̦țo yukto 'yam edhate | pāpadrștiyutau nāśo miśrair miśraphalam vadet \|

1 śrī ... namaḥ] om. N G || vicārādhyāyah] vicāraḥ B 3 -ānadhigamya] -ādhigamya B N 4 nește] ] ṛște K; dṛște T M 5 tanvādika] tattvādika M 7 samarasiṃhenoktāḥ] samarasiṃhena B N 8 suhṛt] suhṛda B N a.c. 12 dṛțti] dṛ̦ța G K T M \| yutau] yuto B N K T M \| nāśo] nāśau $\mathrm{G}$

3-6 bhāvaṃ ... athāham] TYS $12.1 \quad$ 11-12 yo ... vadet] VT 5.1; cf. BPH 74.10

1 Most text witnesses include this renewed (if brief) introductory benediction to mark the beginning of the latter half of the Hãyanaratna.

2 A pun on the word bhāva, which can mean both 'nature' and 'horoscopic house'.

3 Friends are not, to my knowledge, found as a signification of the fourth house in Greekor Arabic-language astrological texts. If of purely Indian origin, it may be the result of

(C) MARTIN GANSTEN, 2020 | DOI:10.1163/9789004433717_008

This is an open access chapter distributed under the terms of the CG BY 4. olicense. 


\section{Judging the Twelve Houses}

\subsection{General Principles of Judgement}

\section{Homage to Śrī Ganeśa! ${ }^{1}$}

Now, the chapter on the judgement of the twelve houses beginning with the ascendant; and Yādava says [in Tãjikayogasudhānidhi 12.1]:

Without studying the nature of another, a wise man is unable to speak of [his] good and bad [traits] even if he wishes to. I shall now expound the good and evil likewise produced by the houses beginning with the ascendant. $^{2}$

The designations of the twelve houses are stated by Samarasimpha [in the Tajjikaśástra]:

[1] Body, [2] wealth, [3] siblings, [4] friends, ${ }^{3}$ [5] children, [6] enemies, ${ }^{4}$ [7] wife, [8] death, [9] piety, [10] action, [11] gain, [12] loss: these twelve houses, beginning with ascendant, are the places of the affairs [indicated by their names].

Next, the general [method of] judging a house is described in Abdatantra $[5.1]::^{5}$

The house that is aspected or joined by its ruler and a benefic prospers; if aspected or joined by a malefic, [there is] destruction [of the significations of that house]; from mixed [planets] one should declare mixed results.

misinterpretation: early Sanskrit works on astrology (such as Yavanajātaka 1.70 and Brhajjātaka 1.15) use the word bandhu 'kinsman', which may represent an intentional or unintentional widening of the signification of parents and ancestors given to the fourth house in Hellenistic astrology. In a secondary sense, however, bandhu may also be understood as 'friend', and this is the meaning taken by later Indian authors.

4 The assignment of enemies to the sixth house is common in Greek and some Arabic texts (see, for instance, Vett. Val. IV 12), although later Arabic and European tradition often reassigns them to the seventh.

5 A synonym of Nīlakaṇțha's Varșatantra. 
atra svāmiśubhagrahānāạm yutau dṛșṭau vā tadbhāvasambandhi svasya saukhyam | ko 'rthạ̣ | tadbhāvoktaśubhapadārthānāṃ vṛddhyā aśubhapadārthānāṃ nāśena ca sukham | pāpais tadbhāvoktāśubhapadārthavṛddhyā śubhapadārthanāśena ca svasya duḥkham | evaṃ miśraị saumyapāpair miśram śubham aśubhạ̣ ca | tatra saumyādhikye sukhādhikaṃ duștạm phalaṃ pāpādhikye duḥkhādhikam śubhaphalaṃ jñeyam | tulyatve krūrasaumyānām balābalavivekena phalanirdeśạ | atra bhāveśamitragraheṇa dṛșto yukto vā bhāvah svaphalado jñeyah | bhāveśaśatruṇā saumyenāpi yuto dṛṣto bhāvaḥ svaphalanāśako jñeyah | bhāvādhīó 'pi lagnād bhāvād vā kendrago bhāvaśubhaphalavṛddhidaḥ | șașțhāșțamadvādaśastho bhāvaphalanāśako jñeya iti viśeșaḥ |

bhāvanātho yathā paśyed bhāvakāryakarah smṛtaḥ|

äkrānto 'pi ca yah paśyet paratah kāryasiddhikrt \||

iti jīrṇatājike | atra viśeșo bhagavatā gargeṇoktaḥ |

nīcastho ripugehastho graho bhāvavināśakrt |

udāsinagrhe madhyo mitrasvarkșatrikonagah $\mid$

svoccagaś ca graho 'vaśyam bhāvavrddhikarah smṛtah || iti |

vyayāṣțașașțhabhāveșu vicāravaiparītyam āha satyācāryaḥ |

1 yutau] yuto M || dṛștau] dṛșțā K T M 3 ca] om. B N || bhāvoktāśubha] bhāvoktāḥ śubha K; bhāvoktaśubha M 4 nāśena] nāśoma $\mathrm{G} \quad 5$ ca] vā B N $\quad 5^{-6}$ sukhādhikaṃ] scripsi; sukhādhikyaṃ B N G; sukhādhikyan K T M 6 pāpādhikye] pāpadṛștẹ B N \| duḥkhādhikam] duḥkhādhikya KT M 8 yukto] yuto G KT M \| phalado] phalaprado G KT M; vā add.

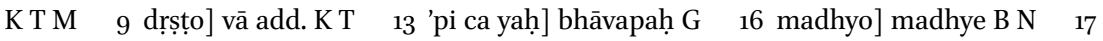
graho] grahe G 18 vyayāṣțașașțha] șașṭhāșțavyaya K T M \|| vicāra] vicāram K T; vicāre M

15-17 nīcastho ... smṛtah] JC 20.10 
Here, when [a house] is joined or aspected by its ruler and benefic planets, one will experience happiness in connection with that house. What does that mean? Happiness [comes about] by increase of the good things signified by that house and by destruction of the bad things. By malefics [joining or aspecting], one will experience misery from increase of the bad things signified by that house and from destruction of the good things. Similarly, by a mixture of benefics and malefics, [there will be] a mixture of good and bad. In that case, it should be understood that if benefics predominate, the evil results are outweighed by happiness; if malefics predominate, the good results are outweighed by misery. If malefics and benefics are equal [in number], the results are predicted by a consideration of their strength and weakness.

On this matter, a house aspected or joined by a planet friendly to the ruler of the house should be understood to give its own results; but a house aspected by or joined to an enemy of the ruler of the house, even if [that planet is] a benefic, should be understood to destroy its own results. And it should be understood that the ruler of the house occupying an angle from the ascendant or from the house [itself] increases the good results of the house; but occupying the sixth, eighth or twelfth [place from the ascendant or the house], it destroys the results of the house. This is a special rule.

Even as the ruler of a house is considered to accomplish the matter of the house if aspecting it, [a planet] occupying [the house] and one aspecting [it] perfect the matter through another [person]. ${ }^{6}$

So [it is said] in the Jirnatäjika. On this matter, a special rule is stated by the venerable Garga:

Occupying its fall or an enemy's domicile, a planet destroys a house; in a neutral domicile it is middling; occupying a friend's or its own sign, its [müla]trikona or exaltation, a planet is considered inevitably to make the house prosper.

Satyācārya states the reverse judgement [to be true] for the twelfth, eighth and sixth houses:

6 A tentative translation of a very terse stanza. 
saumyāḥ pușțim pāpā viparyayaṃ saṃśritā grahāḥ kuryuḥ| mūrtyādiṣu nidhanāntyārișu bhāveșūtkramāt phalaṃ dadyuḥ || iti |

ayam arthạ̣ | așțamasthāḥ saumyā mṛtyuhāniṃ kurvanti | pāpā mṛtyuvṛddhị kurvanti | dvādaśe saumyā vyayahāniṃ krūrā vyayavṛddhim | șașțhabhāvasthāḥ saumyāḥ śatruhāniṃ krūrāḥ śatruvưddhiṃ kurvantīti satyācāryamatam | șașțhe saumyāḥ śatruvṛddhiṃ krūrāḥ śatruhāniṃ kurvantīti tājikakartṛmatam | tad agre grahāṇāṃ bhāvaphale prakaṭibhaviṣyati | atra viśeșam āha samarasiṃhah |

janmani yasmin rāśau śubho 'śubho vā sa varșalagne 'pi yadi bhavati tadā pūrṇaṃ śubhāśubhaṃ yacchati svadhātuvaśāt \| drșțvā navāmsśakabalam śubhadrgyogam ca sarvakāleșu| praștuh śubham ākhyeyam viparîtam vyatyayād eșām || iti |

atra viśeșāntaram āha tejaḥsiṃhaḥ |

lagnaprabhrtyakhilabhāvapatau vinaște

tadbhāvajārthavișayakșatir ittham atra |

naște 'ripe ripurujo 'panayo 'ntyanāthe

nārthavyayaś ca mrtipe mrtihānir ittham || iti |

atha bhāveșu balișthagrahalakṣaṇam uktaṃ saṃjñātantre |

lagnakarmāstaturyāyasutānikastho balī grahah |

yathādimam viśeșeṇa satrivitteșu candramāh $\|$

kujah satrișu prcchāyām sūtau varșe ca cintayet |

1 viparyayaṃ] viparyaye B N K M $\quad 2$-āntyāriṣu] -āṃtyāri G; -āntāriṣu K; -ātyāripu T; -āntā ripu M \| -ūtkramāt] -utkramāt B; -ūkramāt N; -ūktakramāt G 7 tājika] jātaka N 8 atra] atha $\mathrm{G} \quad 10$ śubhāśubhaṃ] śubham K T M $\quad$ 11-12 dṛsțtvā ... iti] om. B N K T M 12 viparītaṃ] scripsi; viparīte G 15 bhāvajārtha] bhāvajātra K T M 17 mṛtipe] om. G 18 graha] om. G

1-2 saumyāh ... dadyuḥ] JC 20.10 14-17 lagna ... ittham] DA 17.3 19-562.2 lagna ... vicintayet] ST $1.58-59$ 
Benefic planets occupying the ascendant and other houses make them prosper, malefics the reverse; in the eighth, twelfth and sixth houses, they give the opposite result.

The meaning is as follows: benefics occupying the eighth [house] avert death, malefics bring on death. Benefics in the twelfth [house] avert loss, malefics bring on loss. Benefics occupying the sixth house avert enemies, malefics bring on enemies. This is the view of Satyācārya. ${ }^{7}$ [But] the view of Tājika authors is that benefics in the sixth [house] bring on enemies [while] malefics avert enemies. ${ }^{8}$ This will become evident below in [the description of] the results of the planets in the houses. Concerning this, Samarasimha states a particular rule [in the Tājikaśāstra]:

In whatever sign a benefic or a malefic [is found] in the nativity, if it appears [there] in the horoscope of the year as well, then it bestows its good or evil results in full according to its own nature. After examining the strength of the ninth-parts and the benefic aspects and conjunctions at all times, good should be predicted for the querent; the opposite if these are contrary.

Concerning this, Tejahsiṃha states another special rule [in Daivajñālaṃkrti 17.3]:

If the ruler of any house, beginning with the ascendant, is corrupt, the matters signified by that house are destroyed. Thus, if the ruler of the sixth house here is corrupt, there is loss of enemies and illness; if the ruler of the twelfth house, there is no loss of wealth; if the ruler of the eighth house, death is averted.

Next, the definition of the strongest planets in the houses is given in Samjñätantra [1.58-59]:

A planet is strong in the first, tenth, seventh, fourth, eleventh, fifth and ninth houses in descending order; also, the moon in particular in the third and second houses, [and] Mars in the third. One should judge

7 For the early and important astrological authority Satya, whose work is no longer extant, see Pingree 1978 II passim.

8 This supposed Täjika view does not reflect the majority opinion of Greek- or Arabiclanguage astrological works. 
bhāvā navettham śastāḥ syū rișphāșțaripavo 'śubhāḥ \|

dīptāmiśätikrame śastā ime 'pîti vicintayet |

atra sarvāpekṣayā lagnastho graho balī | tasmād daśamastho hīnabalaḥ | evaṃ sarvatra | dvādaśāșțamașașțhabhāvā ganitāgatā adhișțhitagrahadīptāṃśān atikramya varteraṃs tadā śubhaphalā iti | evạ̣ śubhabhāveșu grahāḥ svadīptāmśamadhyeșv atyantaṃ śubhāḥ | tadatikrame nyūnaphaladā ity anuktam api jñeyam \|

viśeșam āha yādavaḥ |

yadyadbhāvapatir graho januṣi so 'trābde 'dhikārī balī

tattatprāptikaro 'thavā januși yadbhāvādhipo 'bde sa ca|

paśyet tam sa tathāvidho yadi ca no paśyet phalam svapnavad

yah kaścit khacaro janau śaradi yadbhastho 'tra tatprāptidaḥ || iti |

anyo 'pi viśeșa ukto hāyanasundare |

yasmin bhāve bhāvanāthena yukto

lagnasvāmì tasya bhāvasya vrddhim |

kuryān nityam mrtyunāthena yukto

yasmin bhāve tasya hāniṃ sadaiva || iti |

atha lagneśo yadbhāvasvāminā sahetthaśālaṃ karoti tadbhāvasambandhipadārthānāṃ varṣe lābhasukhādikaṃ vācyam | tatrāpi maṇaūkhallāsararaddayogādisambhave itthaśālaphalaṃ na vācyam | evam itthaśālāsambhave 'pi yamayānaktatambīrayogādau phalaṃ granthoktạ̣ vācyam iti bhāvavicārādhyāyānuktam api jñeyam | atra jātakavarṣapraśnādau lagnā-

1-2 bhāvā ... vicintayet] om. G 4 gatā] om. G 5 varteraṃs] vartate K; vartaṃte T M \| phalā] phaladā G K T M 6 madhyeșv] madhyastheșv G 7 jñeyam] bhāvavicāre add. G 8-12 viśeșam ... iti] om. G 10 tat $^{1}$ ] om. $\mathrm{K}$ || bhāvādhipo] bhāvodhipo B N || sa ca] sarve B $\mathrm{N}$; sa ve G 11 tathā] thā N \| svapnavad] svamavad N 12 'tra] va N 17 tasya] tasyā B N 19 tatrāpi] tatropi $\mathrm{N} \quad 20$ radda] hadda $\mathrm{M} \|$ itthaśālā-] itthaśāla- B N $20-21$-sambhave] -samve T 21 granthoktaṃ] graṃtholaṃ N; yathoktaṃ anyadvārā G; yathoktaṃ T

9-12 yad $^{1} \ldots$ prāptidaḥ] TYS 12.10

22 jñeyam] At this point G adds the quotation from TYS 12.10 omitted after the previous occurrence of the phrase apijñeyam. 
thus in a question, a nativity, and a [revolution of the] year. Thus, nine houses are good; the twelfth, eighth and sixth houses are bad; [but] if they exceed the orbs of light, one should judge even these to be good.

That is, a planet occupying the ascendant is the strongest of all; less than that in strength is one occupying the tenth; and so in all [the houses, strength decreases gradually]. Should the twelfth, eighth and sixth houses, derived by calculation, be so arranged that they exceed the orbs of light of the occupying planets, then they give good results. Likewise, although it is not stated, it should be understood that planets in good houses, the cusps of which fall [within] their orbs of light, are exceedingly good; [but] when [the cusps] exceed those [orbs, the planets] give lesser results.

Yādava [in Tājikayogasudhānidhi 12.10] states a special rule:

Whatever house a planet rules in the nativity, if it has authority in this year and is strong, it makes [the native] attain [the significations of] that [house]; or if, in the year, it aspects the house that it rules in the nativity. If it is such but does not aspect, the result is [insubstantial] like a dream. Whatever planet occupies any sign [both] in the nativity [and] in the year, it gives the attainment of [the significations of] that [sign].

Another special rule is stated in the Hāyanasundara:

If the ruler of the ascendant is joined to the ruler of any house in that house, it always causes that house to prosper; [but] joined to the ruler of the eighth house in any house, it always [causes] the destruction of that [house]. ${ }^{9}$

Also, if the ruler of the ascendant forms an itthaśa la with the ruler of any house, happiness from the gain of the objects signified by that house and so forth should be predicted in [that] year; however, if configurations such as manaū, khallāsara or radda are present, the results of the itthaśăla should not be predicted. Likewise, even in the absence of an itthaśăla, if configurations such as yamayā, nakta or tambira [are present], it should be understood that the results described in books are to be predicted, even though [this is] not stated in chapters on the judgement of houses. Regarding this,

9 This verse is not attested in the available independent witness of the Hayanasundara. 
didvādaśabhāvāḥ sādhyāḥ | tato yatra yatra bhāve yad yad vastu kathitaṃ tattadvastvabhiprāyādi grahayogato vācyam | uktaṃ ca caṇḍeśvareṇa |

yadyadbhāve tuyad vastu kathitam yavanādibhị | tatkāryasamjiñam ākhyātam tatạ praśnādi cintayet ||

iti sāmānyato bhāvavicāraḥ ||

atha viśeșabhāvavicāro 'trādau tanubhāvavicāraḥ | tatra tanubhāve kiṃ cintanīyam ity uktạ̣ caṇḍeśvareṇa |

ārogyapūjāguṇamānavrttam āyur vayo jñātijadoșasaukhyam | kleśäkrịti lakṣaṇavarṇarakșā tadbhāgineyasya vadhūs tanoh syāt ||

atra tanubhāvaś cet svāmisaumyābhyāṃ dṛșṭo yukto vā syāt tadā dehe 10 ārogyam lokatah pūjālābhạ guṇodayạ̣ sanmānādhikyam śubhācaraṇam āyuși nirvighnatā lagneśavayasā puruṣeṇa sukhādhikyaṃ svajñātisukhaṃ kleśanāśạ̣ śubhākṛtitvam nāmakāntivardhanaṃ dehe subhalakṣaṇodgamaḥ lagnādhissasya saṃjñātantroktabrāhmaṇādivarṇadvārayā sukham anggarakṣā bhāgineyajāyādehe sukhaṃ bhāgineyavivāhādyutsavena vā sukham | evaṃ pāpaiḥ sarvaṃ viparītạ̣ jñeyam | miśrair miśraṃ ca pūrvavaj

1 yad $^{1}$ ] om. G $\quad 2-3$ tat ... kathitam] om. B N 2 yogato] yogito G; yogattī K 3 bhāve tu] bhāveșu G 4 saṃjñam ākhyātaṃ] saṃjñām ākhyātam B N; ciṃtavākhyānāṃ G 6 vicāro 'trādau] vicāre | ādau G; vicāre ādau K T M 8 jñātija] jñātica B N 9 ākṛtī] ākṛtā N || tanoḥ] tanau K T M 12 vayasā] vayasāṃ B N || sukhādhikyaṃ] sukhā'dhikaṃ M || jñāti] jāti G \|| sukhaṃ] saukhyạ̣ K T M 13 vardhanaṃ] varddham B N $\quad$ 13-14 -odgamaḥ] -odayah G 
in a nativity, [revolution of the] year, or query, the twelve houses beginning with the ascendant should be established, and from them, the signification of whatever matter is assigned to each house and so on should be predicted by the configurations of the planets. For Candeśsara says:

The matter that is assigned by Yavana and others to each house is called the topic signified by that [house]. From that one should judge queries and so on.

This concludes the general [method of] judging a house.

\subsection{The First House}

Next, the judgement of individual houses, beginning with the judgement of the first house. Regarding that, Candeśvara describes what is to be considered from the first house:

Health, homage, virtues, honour, conduct, longevity, age, harm or happiness from relatives, suffering, appearance, attributes, estate, ${ }^{10}$ safety, and the wife of one's nephew ${ }^{11}$ are [to be predicted] from the first house.

Here, if the first house should be aspected or joined by its ruler and a benefic, then the body is healthy, one receives homage from the people, there is a dawning of virtue, an abundance of honours, good conduct, no obstacles to longevity, abundant happiness from a person of the age [signified by] the ruler of the ascendant, happiness from one's relatives, an end to suffering, good appearance, increase in name and beauty, emergence of auspicious signs on the body, happiness by means of the estate signified by the ruler of the ascendant according to the Samjiñatantra, such as the Brahmans, physical safety, pleasures of the body for the nephew's wife or happiness from celebrating the wedding of the nephew and so forth. Similarly, by malefics [aspecting or joining the first house] the opposite of all this should be under-

10 That is, social class (varna). This is the interpretation adopted by Balabhadra, but an equally likely meaning is 'colour'. Very possibly both are intended.

11 This last signification is only one of many possible examples of derived (secondary, tertiary, and so forth) house meanings: siblings belong to the third house; their children, to the seventh house (this being the fifth from the third); and the spouses of the latter, to the first house (seventh from the seventh) - counting inclusively at each step. 
jñeyam | atha viśeșayogās tājikasāre |

lagnādhipe pūrnabale 'tisaukhyam ārogyatā kāntivivardhanaṃ ca | alpam sukham madhyabale vinașțe kaștam vyayāșțārigate 'lpasaukhyam ||

atra varṣalagneśo janmany api pūrṇabalopekșita ity uktaṃ tejaḥsiṃhena |

lagneśvare 'bdajanuṣor api pūrnaviōrye

nīrogatāmatimahattvavapuhsukhāni|

lagne 'tha drștasahite vibhunā śubhair vā

bhāveșu caivam akhileșu phalam vilokyam \|

evaṃ pāpaih sarvaṃ viparītam jñeyam | miśrair miśraṃ ca phalaṃ bhavet |

kendrasthite lagnapatau ca saumyair drsțte yute vā navapañcamasthaih |

saukhyam vilāso vijayo bhaved vā kambūlage rātripatau balậ̣hye \|

lagnam yadā pāpakhagaiḥ sametam saumyagrahair no sahitaṃ ca dṛștam |

dadāti māndyam bahulam samānte tathā vivādam kujanair narānāàm \|

śubhagrahāḥ kendragatā balānvitāḥ sadyo 'rthalābhāya sukāryasiddhaye |

pāpagrahāh pañcamadharmakendragā dāridryaduhkhāya bhavanti tatra \| saumyagrahair upacayopagataih samastair lagnāt tathā himakarāt sabalair narāṇām | dadyur dhanāni vividhāni vilāsahāsyam saukhyāgamam nikhilalokajanāt prthivyām \|

\footnotetext{
2 ārogyatā] ārogyatān K T 3 gate] gato B N a.c. 4 varșa] varșe $\mathrm{N}$ \| janmany api] janmavyapi G 7 dṛșța] dṛști B N \| sahite] sahito G \| vibhunā] vibhutā B N G 8 caivam] tatram B 9 evam ... bhavet] om. G \| miśram ca] miśra K T M 10 -sthaih] scripsi; -sthe B N G K T M 15 dharma] om. B N K T M || kendragā] vā add. B N K T M 16 saumya] sau T 19 loka] scripsi; yoga B N G K T M

2-3 lagnā- ... saukhyam] TS $190 \quad 5^{-8}$ lagneśvare ... vilokyam] DA $17.2 \quad 10-11$ kendra ... balāḍhye] TS191
}

19 loka] The emendation is supported by Mss TS1, $\mathrm{TS}_{2}$ and $\mathrm{TS}_{3}$. 
stood [to occur], and by mixed [planets], mixed [results] should be understood [to occur], as above. Next, particular configurations [are described] in Tājikasāra [19o]:

If the ruler of the ascendant has full strength, there is great happiness, good health and increase in beauty; if it is of middling strength, there is little happiness; if it is corrupt, there is evil; if occupying the twelfth, eighth or sixth house, little happiness.

Here the ruler of the ascendant of the year is expected to have full strength [and so on] in the nativity as well: thus [says] Tejahsiṃha [in Daivajñālaṃkṛti 17.2]:

If the ruler of the ascendant has full strength both in the year and in the nativity, there is good health, greatness of mind, and pleasures of the body, if the ascendant is also aspected or joined by its ruler or benefics. Results should be considered thus for all the houses.

Similarly, by [the aspects and occupancy] of malefics, the opposite of all this should be understood [to occur], and by mixed [planets], the results will be mixed. [Continuing from Tãjikasāra 191:]

If the ruler of the ascendant occupies a quadrant, aspected by or joined to benefics occupying the ninth or fifth [house], there will be happiness, delight and victory, or if the moon endowed with strength forms a kambūla.

When the ascendant is beset by malefic planets and neither joined nor aspected by benefic planets, it gives men much illness at the end of the year, and likewise disputes with evil people. Benefic planets occupying angles and endowed with strength immediately leads to gain of wealth and the accomplishment of good deeds; but malefic planets placed in the fifth, ninth, or angles lead to poverty and suffering. By all benefic being planets strong and occupying places of increase ${ }^{12}$ from the ascendant as well as from the moon, they give manifold riches, delight and laughter, and gain of happiness from all the people in the world. ${ }^{13}$

12 See Chapter 5 , note 84.

13 The verses in this paragraph are not attested in available independent witness of the Tājikasāra. 
samarasiṃhạ |

lagneśe kendrasthe śubhagrahe lagnage śubhair drșțe |

lagnāt trikoṇasamsthe kṣemam dehasya candramūthaśile \|

yadi lagne lagnapatih saumyayuto vā vilokitaḥ saumyaih |

tat praștur vyākulatā śarīradoṣā vinaśyanti ||

yatrarkṣe lagneśas tatpatir aśubhe gṛhe tadā kāryam |

na syād aste kașțād daśamadrśā kațukatā kārye \|

jātakalagnād varșe șașthe 'ntye vā drśā grahaiḥ krūraị̣|

drșțe yute ca vācyam tadvarșe na śubham anyayoge 'pi ||

janmani pāpe varșe lagnagatā munthahā na hi śreșțā|

10

krürayutadrșțacandre lagnasthe vāśubham bahuśạ̣ \|

lagnāt saptāṣtamage bhaume varșam na śobhanam vācyam |

jīrṇatājike |

udito lagnapo lagnam paśyet sarvagrahekșitam |

sārvabhaumas tadā yogo mahābhāgyasya jāyate \|

yadrāśijo naras tasya samudeti patir yadā|

rāśiśasyodayo vā syād udayas tatra vatsare \|

2 grahe] grahai $\mathrm{T} \|$ śubhair] śubhe $\mathrm{K} T \quad 3$-samsthe] -sthe $\mathrm{G} \quad$ 4-7 yadi ... kārye] om. B N K T M 8 varșe] varșaṃ G $\|$ dr̛śā] daśā N K T M 12 lagnāt ... vācyam] om. B N $\quad 15$ sārva] sarva B N 16 rāśijo] rāśito B N $\quad 17-570.1$ rāśí ... 'thavā] om. G 17 -odayo] -odaye B N

15-574.21 mahā ... varșe] Folios $3^{\mathrm{v}}$ and $4^{\mathrm{r}}$ are missing from the scan of T. 
[And] Samarasiṃha [says in the Tājikaśāstra]:

If the ruler of the ascendant occupies an angle and a benefic planet occupies the ascendant aspected by benefics [or] is placed in a trine from the ascendant with a mutthaśila from the moon, there is bodily well-being. If the ruler of the ascendant is in the ascendant joined to a benefic or aspected by benefics, then the querent's anxiety and ailments of the body vanish.

[If] the ruler of the sign where the ruler of the ascendant [resides] is in a malefic house, ${ }^{14}$ then the querent's purpose will not be accomplished. If it is [heliacally] set with a tenth-[sign] aspect from a malefic, violence will accompany his affairs.

If the year [falls] in the sixth or twelfth house from the ascendant of the nativity, ${ }^{15}$ aspected by malefic planets with an aspect or joined [to them] ${ }^{16}$ no good should be predicted for that year even in [the presence of] other configurations.

The munthaha occupying the ascendant is not very good if there is a malefic in the [sign corresponding to that] year in the nativity. If the moon occupies the ascendant joined to or aspected by a malefic, evil abounds. If Mars occupies the seventh or eighth [house] from the ascendant, the year should not be declared to be good.

[And] in the Jïrnatājika [it is said]:

Should the ruler of the ascendant, [heliacally] risen, aspect the ascendant [which is also] aspected by all [other] planets, then an allconquering configuration is formed for the greatly fortunate [native].

When the ruler of the sign under which a man was born rises [heliacally], or the [heliacal] rising of the ruler of [that] sign takes place, [the native] rises up in that year. ${ }^{17}$

14 Grha, which in the present context could mean either the domicile of a malefic planet or one of the evil houses (6, 8 or 12).

15 Presumably by the annual profection of the ascendant (the munthahā); see the Introduction.

16 The phrase 'aspected [...] with an aspect' seems either redundant or incomplete (for 'aspected $[. .$.$] with an evil aspect'), but there is no basis in the text witnesses for an$ emendation.

17 The two conditions given appear to be entirely synonymous. Possibly the text is corrupt, but there is nothing on which to base an emendation. 
uditah svoccago vāpi rāśipo lagnapo 'thavā

śubham tadvatsare tasya kuryād yukto 'thavā grahah $\|$

lagneśo vīkșate lagnaṃ vīkșante ca śubhagrahạh |

tadā dehasukham vindyāl lagne lagneśvaro 'thavā $\|$

lagnam lagneśvaraḥ paśyed bhāvam paśyati bhāvapạ̣|

tāv ubhau bhāvagau syātāṃ tadā tadbhāvajam sukham ||

svakșetrastho lagnapatir lābhapena yutah śaśî |

śreștho dhanādhipaś cet syāt tadā śreșthaphalāptikrt ||

kendrago yadi lagneśạ śubho drșțah śubhair api |

trikonalābhago vāpi candrāgre kșemakārakah ||

jīve 'bdape krürayute lagne hānir bhayam nrpāat |

șaștho lagnādhipo nūnam svayam eva ripur bhavet |

aștamo mrtyukrc caiva vyayago vyayakārakah $\|$

lagnanāthe vinașțe syād vinașțāvayavah pumān |

tejovarnādikam naștam udite nikhilaṃ śubham \|

lagnanātho rāsināthah kendranātho 'tha bhāvapaḥ|

udeti yatra māse ca tanmāse tatsukham bahu \|

uditāv uttame bhāge rāśilagnapatī sthitau |

kendre vā syuh śubhā hy evam tadā śreșthaphalam smṛtam \|

yasmin grhe lagnapatis tadīsah syāc chubhe gṛhe |

śubhakāryasya siddhih syād viparïte na sambhavaḥ \|

3 vīkșate] scripsi; vīkṣyate B N G K M || vīkṣante] vīkṣyaṃte B N KM 4 vindyāl] vidyāl K M 9 śubho dṛșțah] śubhadṛșțạ̣ B; om. N || api] vilokitaḥ add. N p.c. 10 lābhago] lagnago B N || candrāgre] ced rājye K M 14 vinaștāvayavah] vinașțah vayavaḥ K 15 naștam udite] naștasudite N; naștam udito G 17 udeti] udite B N $\|$ māse ${ }^{1}$ ] nāthe B N 19 śubhā hy evaṃ] śubhāpy evaṃ B N; śubhāthevaṃ G \|| śreșțha] śreșțhaṃ G K $\quad 20$ gṛhe ${ }^{1}$ ] grahe G; gehe K M

14-15 lagna ... śubham] G transposes these two half-stanzas. 
[Heliacally] risen or occupying its exaltation, the ruler of the sign [occupied by the moon in the nativity] or the ruler of the ascendant will bring good to him in that year, or a planet joined [to the ruler will do the same].

[If] the ruler of the ascendant aspects the ascendant and benefic planets aspect [it too], then he will have pleasures of the body, or [if] the ruler of the ascendant is in the ascendant.

Should the ruler of the ascendant aspect the ascendant, and the ruler of a house aspects [that] house, or should both of them occupy the house, then there is happiness from that house.

If the ruler of the ascendant occupies its domicile, the moon is joined to the ruler of the eleventh house, and the ruler of the second house is excellent [by dignity], then it brings excellent results.

If the ruler of the ascendant occupies an angle, benefic and aspected by benefics, or it occupies a trine or the eleventh house ahead of the moon, ${ }^{18}$ it causes well-being.

If Jupiter as ruler of the year is joined to a malefic in the ascendant, there is loss and danger from the king. [If] the ruler of the ascendant is [in] the sixth, [the native] will become his own enemy; [in] the eighth, it will cause death, and occupying the twelfth house, it will cause loss.

If the ruler of the ascendant is corrupt, a man will lose limbs; his vigour, colour and so on will be lost; [but] if [the ruler of the ascendant is heliacally] risen, all is well.

In the month in which the ruler of the ascendant, the ruler of the sign [occupied by the moon in the nativity], the ruler of an angle or the ruler of a house rises [heliacally], in that month there is much happiness from that [planet's significations].

Should the rulers of the sign and of the ascendant, [heliacally] risen, occupy the highest degree ${ }^{19}$ in an angle, or should the benefics be [placed] thus, then excellent results are declared.

Should the ruler of the house in which the ruler of the ascendant [resides] be in a benefic house, ${ }^{20}$ good deeds will be accomplished; in

18 The meaning seems to be that the moon is approaching an exact conjunction (or possibly an aspect) with the ruler of the ascendant.

19 Presumably the degree of exaltation is meant, in which case the two planets cannot be conjunct, as each planet has its own sign and degree of exaltation. An alternative meaning is 'the last degree', but this does not seem to agree with astrological doctrine.

20 In both instances, the word for 'house' in this sentence is grha. In the first instance it clearly refers to the domicile of a planet; the second is less clear. 
nīcasthite cāstamite aśubharkșasthite tathā

lagneśabhapatau kāryam aśubham tatra sidhyati $\|$

lagnakāryapayor yogaḥ śubhayoḥ siddhikrd bhavet |

pāpayoś ca tayoryogo alpakāryakaro matah $\|$

hillājah |

vilagnāt pañcamam tasmāt punyabham ca tatas tanuh | sthānatraye yadā saumyāh sukhasampat tadā bhavet \| svoccam tatra yadā saumyās tatra rājyam mahāsukham | svocce lagne śriyam turye saukhyam yoṣid dyune bhavet | vyomni rājyam graham samyag vicārya phalam ādiśet \|

yādavaḥ |

janmāñgābdapatih samātanupatir vābde bhaved yadbhagas tadbheśena krtetthaśālayutikas tattatpradaś cec chubhaḥ| yad vā bhāvanrpo 'thavā sahamapo varșādhināthena vā lagneśena karoti ced yutim ihāsyāptiprado hāyane \| lagneśvare vā śaradīśvare vā vīryānvite saumyayutekșite ca | śarīrasaukhyam bahuduḥkham aștașașțhasthite tatpatinātha yukte \| janmalagnapatir uttamaviryo yadgrhe januși tatra ca drșțe | tena vā sahita asya ca labdhis tad yathāngasukham abdatanau syāt $\|$ bhāvā janmani hāyane svaphaladāh saumyasvapekșāyutā

1 aśubharkșa] aśubharkșe $G \quad 2$ sidhyati] siddhāti $K \quad 4$ yogo] yoga $\mathrm{K} \mathrm{M} \quad 6$ vilagnāt] lagnāt $\mathrm{K} \|$ puṇyabhaṃ] puṇyabhe $\mathrm{G} \quad 7$ sampat tadā] sampattido $\mathrm{M} \quad 8-9$ svoccaṃ ... bhavet] om. B N 10 grahaṃ] scripsi; grahe B N G K M 13 tattatpradaś] tatprāptidaś G K M 14 yad vā] yadbhā K 17 patinātha] patinā ca G K M 18 gṛhe] grahe B N 19 ca labdhis] tv alabdhis G 20 bhāvā] bhāvaṃ B N || janmani] janmati N || saumya] saumyā B N; saumyais K M || svapekṣā] svadyekṣā N; svapatyā K M

12-17 janmā- ... yukte] TYS 12.12-13 18-19 janma ... syāt] TYS $12.15 \quad 20-574.7$ bhāvā ... dhāyane] TYS 12.118-119

19 sahita] This sandhi (for sahite), rare but not unheard of, is confirmed by independent witnesses TYS1, TYS2. 
the opposite [situation], they cannot. If the ruler of the sign [occupied by] the ruler of the ascendant occupies its fall, is [heliacally] set, or occupies a malefic sign, ${ }^{21}$ evil deeds are accomplished. A configuration of the rulers of the ascendant and the matter sought, both benefic, will accomplish [the matter], but their configuration when both malefic, is said to produce only a little of the matter.

[And] Hillāja [says]:

The fifth from the ascendant, the ninth sign from it, and then the ascendant: when benefics are in [these] three places, then happiness will abound. When the benefics [are in their] exaltation there, there is dominion and great happiness. In exaltation in the ascendant, [a benefic will make] splendour; in the fourth, happiness; in the seventh house, there will be a wife; in the tenth house, dominion. Having examined the planet carefully, one should predict the result.

[And] Yādava [says in Tājikayogasudhānidhi 12.12-13, 15, 118-119]:

Should the ruler of the ascendant of the nativity, [the ruler] of the year, or the ruler of the ascendant of the year form an itthaśāla configuration with the ruler of the sign that it occupies in [the revolution of] the year, it bestows [the matter signified by] that [sign], if it is a benefic; or else, if the ruler of a house or the ruler of a sahama makes a configuration with the ruler of the year or the ruler of the ascendant, it bestows the attainment of [the matter signified by] that [house or sahama] in that year. If the ruler of the ascendant or the ruler of the year is endowed with strength and joined to or aspected by benefics, there are pleasures of the body; [but there is] much suffering if [the same planet] occupies the eighth or sixth [house] joined to its ruler.

If the house in which the ruler of the ascendant of the nativity is [placed] with excellent strength in the nativity is aspected or joined by that [ruler, there is] attainment of [the matter signified by] that [house]: for example, [if it is placed] in the ascendant of the year, there will be pleasures of the body.

The houses of the nativity give their own results in the year when joined by the aspects of the benefics and their own rulers; if the reverse, 
vyastā vyastaphalāś ca tat paridṛ̣̂hạh sādāh sameśo 'pi ca | evam cāpi vilagnavad dhanasukham cakram vidhāyātra tu duștādușțakhagodayāstadinato brūyāc chubham cāsubham || sūtau yadbhavane subho 'bdasamaye tadgo 'ñgato 'bdāngato munthāto 'pi tadāptikṛt kṣatikaraḥ krūro 'tha varșeśvarah | yadbhāve sahame 'tiviryasahito lagneśvarenāpi vā tatpenātha kṛtetthaśālayutikas tatprāptikrd dhāyane \|

tejaḥsiṃhah |

varșāngapo januși yadgṛhago balī syād varșe ca lagnam atha tadgrham āśritaś cet | tadbhāvajam khalu phalaṃ sakalaṃ dadāti cettham sadātra muthahābdapatī vicintyau \|

atra varșalagneśaphalam āha samarasiṃhah |

yadi lagneśạ̣ sūryo duḥkham ca vyākulatvaparavaśate | yadi somas tu parānnam bhuñkte 'tho nāśrayo vigatadhātuh $\|$

bhaume lagnādhipatau sarvavirodhī vivādakrd rogī| saumye ca patau vidyābuddhiprabhrtīni jāyante \| gurusitayoś ca patitve sukhāni pūrṇāni sarvāṇi | mandapatitve kalahodvegavikārāśubhāni syuh || iti |

janmaniye balayuktā hinabalā ḍhyās tathā varșe | te varșapūrvabhāge śubhaphaladāś cottare tv aśubhāḥ ye janmani balahīnā varṣe balasaṃyutāḥ khețāh | te varșacaramabhāge śubhaphaladāh pūrvabhāgake tv aśubhāḥ\|

1 dṛ̣hāḥ] dṛ̣hhas K $\quad 2$-vad dhana] varddhana B N || sukhaṃ] mukhaṃ N; svakhañ K || tu] tad K M 3 -odayā-] scripsi; -āhvayā- B N; -āśrayā- G K M 4 tadgo 'ńgato] scripsi; tadgoṃtago B N; tadgoh 'gatoḥ G; tadva gato K; taddharmato M 6 bhāve] bhāvo N || sahito] sahite B N $\quad$ 6-7 vā tatpenātha] vā tat svenātha B; vāstv etenātha N 7 kṛtetthaśála] kṛtotthaśāla N; kṛtthaśāla K 9 gṛhago] grahago B N 11 dadāti] dadhāti B N $13-19$ atra ... iti] om. B N 13 lagneśa] lagne M 15 parānnaṃ bhunkkte 'tho] scripsi; parānnabhuktātho G; parānnabhukūlatho K; parānnabhuk kulato $\mathrm{M} \quad 18$ patitve] pativi K; pativati M 21 balāḍhyās] balādyās N K M 22 varṣa] om. B N 23 ye] ca add. K T || saṃyutāḥ] yutāḥ B N 24 varșa] varșe $\mathrm{K}$ T M

9-12 varșā- ... vicintyau] DA 17.1 
they reverse their results: that [is if they are] powerful, and [likewise] the lots and the ruler of the year. Arranging the circle [of houses] thus, as with the ascendant, [there is] happiness from wealth [from the second house, and so on]. From the days of [heliacal] rising and setting of malefic and benefic planets, one should predict good and evil. In whatever house a benefic [resides] in the nativity, occupying that [house] at the time of [the revolution of] the year, [as reckoned] from the ascendant [of the nativity], from the ascendant of the year, or from the munthaha $\bar{a}$, it causes the attainment of [the matter signified by] that [house]; a malefic causes [its] destruction. And in whatever house or sahama the ruler of the year [resides], endowed with great strength and forming an itthaśāla configuration with the ruler of the ascendant or with the ruler of that [house], it causes the attainment of [the matter signified by] that [house] in [that] year.

[And] Tejaḥsiṃha [says in Daivajñālaṃkrti 17.1]:

Whatever house the ruler of the ascendant of the year occupied in the nativity, being strong, if it should occupy the ascendant or that [same] house in [the revolution of] the year, it surely gives the full result arising from that house. The rulers of the muthah $\bar{a}$ and of the year are also always to be considered thus.

Concerning this, Samarasiṃha [in the Tājikaśāstra] states the results of the ruler of the ascendant of the year:

If the sun is ruler of the ascendant, there is suffering, agitation and subservience to others. If the moon [is ruler, the native] eats another's food, has no shelter and is without substance. If Mars is ruler of the ascendant, he opposes everyone, makes quarrels and is sickly. If Mercury is ruler, learning, understanding and so forth arise. If the rulership goes to Jupiter and Venus, all pleasures are complete. If Saturn holds rulership, there will be evils of strife, agitation and ailments.

Concerning this, Hillāja states a special rule:

Those [planets] that are endowed with strength in the nativity but have little strength in the year give good results in the former part of the year but are evil in the latter. Those planets that have little strength in the nativity but are endowed with strength in the year give good results in 
ubhayatra ye balā ubhayatra viryarahitās te varșe 'niștadāh sakale \|

atha lagnabhāvasthitānāṃ sūryādīnāṃ phalaṃ tājikapadmakośe |

atha pravaksye yavanāditattvaṃ tanvādigānāṃ ravipūrvakāṇām | sāmānyato bhāvaphalaṃ khagānām kautūhalād daivavidām hitāya \| ravir lagnago vātapittam karoti kalatrāngapị̂ạ̣̄ śiro'rtyakșirogam | vivādam janānām bhaved guptacintā daśā neștakārī bhaved dhāyane 'smin $\|$ tanugatas tanute rajanīkaro vikalatāị ca kaphajvarapịdanam | bhavati pāpakhagānvitadrg yadā tanuvināśakaro balavarjitah $\|$ dharanitanayalagne syād vraṇam vātapīịa bhavati ripuvivādo netraśírșe ca rogaḥ| jvaravamanavikārād añganānām ca kașțạn nrpabhayam atha lohād agnito vā bhayam syāt $\|$ rajanikarasutah syāl lagnago hāyanasya bahulabalavivọddhir yoșitām cāpi saukhyam | bhavati ripuvināśo bhüpapakșāc ca lābho dhanajanasukhakārī mitralābhaṃ karoti $\|$ jīve lagnagate hayāmbarasukham prāpnoti vrddhiṃ parām rājyāt saukhyasamāgamam ca bahulaṃ vyāpāratah syāj jayaḥ| kìrteś cāpi vivardhanaṃ ripujanā naśyanty avaśyam tathā jāyāsaukhyam athāpi mauktikadhanam hemnaś ca lābho bhavet \| tanusthānago bhārgavaś ced iha syāt pratișthāvivrrddhim samrddhyāgamam ca| ripūnāịn vināśam tathā bhūpamānam jayaṃ bhūṣaṇādyaṃ narāṇām karoti \| mürtisthito ravisutaḥ sutalābhakārī hy uccasthitah svabhavane ca karoti labdhim |

\footnotetext{
1 balāḍhyāḥ] balādyāḥ N $\quad 2$ sakale] pi add. M $\quad 5$ kautūhalād] kautūhalaṃ G K T M $\quad 11$ khagānvita] guganvita $\mathrm{G} \quad 12$ vraṇaṃ] vraṇo $\mathrm{G}$ T; dhaṇo $\mathrm{K} \quad 14$ aṅganānāṃ] aṃganāṃge $\mathrm{K}$ T M 16 hāyanasya] hāyane syād $B N \quad 21$ rājyāt] rāt $N \quad 22$ janā naśyanty] jano naśyaty $\mathrm{G}$ 23 hemnaś] hemaś K T 27 bhūṣaṇādyaṃ] bhūṣaṇāḍhyạ̣ K T M

4-5 atha ... hitāya] TPK o.2 6-9 ravir ... 'smin] TPK 1.1 10-11 tanu ... varjitah] TPK 2.1 12-15 dharani ... syāt] TPK $3.1 \quad 16-19$ rajani ... karoti] TPK $4.1 \quad 20-23$ jïve ... bhavet] TPK 5.1 $24-27$ tanu ... karoti] TPK 6.1 $28-578.2$ mūrti ... madhye] TPK 7.1
} 
the latter part of the year but are evil in the former part. Those that are rich in strength in both [figures] will bestow good for the entire year, but those bereft of strength in both give evils the whole year.

Next, the results of the sun and other [planets] occupying the first house [are described] in Tājikapadmakośa [0.2, 1.1, 2.1, 3.1, 4.1, 5.1, 6.1, 7.1, 8.1]:

Now I shall describe the truth [according to] Yavana ${ }^{22}$ and others: the general results of the sun and other planets occupying the ascendant and other houses, from an eager desire for the well-being of astrologers.

The sun placed in the ascendant makes [an excess of the humours of] wind and bile, bodily pain for the [native's] wife, headache and ailments of the eyes and quarrels with people [in general]. There will be secret anxiety, and its period in this year will not bring any good.

The moon placed in the ascendant makes defects, suffering from phlegm and fever; when it is bereft of strength and joined to or aspecting malefic planets, it destroys the body.

When Mars is in the ascendant, there will be wounds and suffering from [the humour of] wind; there are quarrels with enemies and ailments of the eyes and head, evils to women [of the family] from disorders with fever and vomiting, and there will be danger from the king and danger from iron or fire.

Should Mercury occupy the ascendant of the year, there is great increase in strength and happiness from women, destruction of enemies and gain from the king's retinue: it brings happiness from wealth and people and makes [the native] gain friends.

If Jupiter occupies the ascendant, [the native] obtains happiness from horses and clothes, great prosperity and gain of abundant happiness from dominion; there will be triumphs in his occupation, his fame will spread, and his enemies inevitably perish; there will be happiness from his wife, pearls and wealth, and gain of gold.

If Venus should occupy the ascendant in this [year], it makes an increase in eminence and acquisition of riches, destruction of enemies and honours from the king, triumphs, ornaments and so forth for men.

Occupying the ascendant, Saturn brings children and gain if occupying its exaltation; in its domicile, it makes gain; in the rest [of the 
śeșe ca vairibhayavāyukṛtā ca pīḍa

jāyāngakaștam atha rogakrd abdamadhye \|

tamo lagnagạ̣ kāmininām ca pịdā

ripor bhîticintā vyayo vyagratā ca|

śiro'rtim ca bhūpād bhayam mānabhañgạ̣

tathā netrapīdām karotīha varșe \|

ketuphalam sarvatra rāhuvaj jñeyam | maṇitthạ̣ |

bahucintā tathodvegam śiro'kșimukhapịdanam |

bahuroșo 'ñganāpịdā varșādau lagnage ravau \|

prakșinaśs candramāh krūraś cākșinnaḥ saumya eva ca |

saumyadrștas tathà saumyah pāpadrșțas tv aśobhanah ||

śuklāsțtamyuttaradalād yāvat krṣnnāștamīdalam |

tāvac chubhaś ca śittāmśuh proktasthāneșu śobhanaḥ ||

lagne śítakare pumsāọn śvāsakāsādipịdanam|

pațalākșivikāraiś ca pịditạ̣ kapharogatah \|

mürdhavaktrādirogāmśs ca kalaham ca dhanakșayam |

raktapittaprakopam ca kurute lagnagạ kujah $\|$

dehe saukhyam dhiyo vṛddhir nrpamānam dhanāgamam |

tejodhairyavivrddhiś ca varșe saumye vilagnage \|

saukhyạ̣ putrakalatrāder vapurārogyasanmatī|

lābham sevāsukhaṃ bhūpamānaṃ lagnagate gurau \|

1 śeșe ca] śeșeșu K T M 3 lagnagam] lagnagaḥ K T M 5 śiro’rtiṃ] śirortiś K T 6 netra]

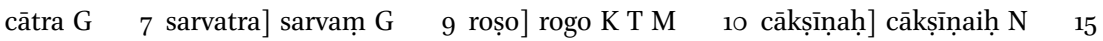
pațalākși] vadanākși $G$ || rogatah] rogadaḥ $G \quad 16$ mūrdha] mūrdhva $G$ || rogāṃś] rogaś B; rogāś N G K T \| ca dhana] vaṃdhana G 17 kujah]] śubhạ̣ B 19 dhairya] dhairyasya K p.c. T M $\|$ vivṛ̂ddhiśs vṛ̂ddhiś K T M || vilagnage] vilagne G

3-6 tamo ... varșe] TPK 8.1 
signs there is] suffering caused by [the humour of] wind and danger from enemies and bodily evils for the wife, and it makes illness in [that] year.

[If] Rāhu occupies the ascendant, there is suffering to women [of the family], danger and anxiety [on account] of enemies, loss and agitation: it makes headache, danger from the king, loss of honour and suffering from the eyes in this year.

The results of Ketu should be understood to be like those of Rāhu in all [houses].23 [And] Manittha [says]: ${ }^{24}$

There is much anxiety and agitation, pains in the head, eyes and mouth, much anger ${ }^{25}$ and suffering to women at the beginning of the year if the sun is in the ascendant.

Waning, the moon is a malefic; waxing, a benefic. Likewise, aspected by benefics it is a benefic, but a malefic when aspected by malefics. From the middle of the eighth day of the bright fortnight up to the middle of the eighth day of the dark fortnight, ${ }^{26}$ the moon is a benefic, good in the places declared [for it]. If the moon is in the ascendant, men suffer from asthma, cough and so on; [the native] is afflicted with cataracts and disorders of the eyes, and with illnesses of phlegm.

Placed in the ascendant, Mars makes illnesses of the head, mouth and so on, strife, loss of wealth, and agitation of blood and bile.

If Mercury is placed in the ascendant in the year, there are pleasures of the body, a broadening of the mind, honours from the king, acquisition of wealth, and increase in vigour and intelligence.

If Jupiter occupies the ascendant, there is happiness from children, wife and so on, a healthy body and a good mind, gain, happiness from service and honours from the king.

23 As Rāhu and Ketu (always identified, in this late period, with the moon's north and south nodes, respectively) are diametrically opposed, this statement by Balabhadra would imply the identical interpretation of the placement of the nodes in each pair of opposing houses (e.g., the first and seventh, the second and eighth, etc.), which does not agree with the descriptions below. It would have been more internally consistent to say that the placement of one node necessarily entails the opposite placement of the other node, so that there is no need to interpret them separately.

24 As discussed in the Introduction, the passages quoted from 'Manittha' in this chapter do not form part of the standard text of the short Varșaphala attributed to that author.

25 Text witnesses K T M read 'illness'.

26 That is, from the waxing half-moon to the waning half-moon. 
saukhyam läbham pramodam ca kulavrddhir bhaven nṛ̣ām |

mānam bhümipater datte daityejyo lagnago yadi $\|$

kaphamārutakopam ca śirojațharapị̂nam |

iștadveșam vaktrapị̄ā varșe lagnagate śanau \|

dehe marutkrtā pịdā kalaham vibhavavyayam |

putramitrādikaṃ kaștam rāhau varșavilagnage \|

iti tanubhāvavicārah ||

atha dhanabhāvavicārah | tatra dhanabhāve kiṃ cintanīyam ity uktạ̣ caṇdeśvareṇa |

māṇikyamuktāphalaratnadhātuvajrāmbarasvarnahayādi sarvam |

raupyādi dhānyam krayavikrayādi sādhāraṇaṃ tat kathitạ̣ dvit̄̄ye \|

atra dhanabhāvaś cet svāmisaumyābhyāṃ dṛșṭo yukto vā syāt tadā māṇikyamuktāphalaratnavajrāmbarasvarṇādīnām āgamāt sukham aśvāditah sukhaṃ krayavikrayād dhanāgamaḥ dhānyavyāpārādito lābhah | krūraị̣ sarvaṃ viparītạ̣ miśrair miśram | atha yogā varșatantre |

vittādhipo janmani vittago 'bde jīvo yadā lagnapatītthaśâlā | tadā dhanāptih sakale 'pi varșe krūresarāphe dhanadhānyahānih \|

yādavena nanu janmani dhanabhāvasthaguror yoga uktaḥ |

yadi devagurur dhane janau śaradi syād api tatra tadbhujā |

muthaśîlayutau tadā dhanaṃ bahulam syād iti niścitaṃ vadet \|

4 pị̄āa pīḍām M 5 marutkṛtā] manukritā K || vyayam] kṣayam M 6 mitrādikaṃ] jāyādikaṃ G 12 atra] a G a.c.; atha G p.c. 13 phala] om. B 18 nanu] janu N; tu G KT M 19 bhujā] yutah K T M

16-17 vittādhipo ... hāniḥ] VT 6.1 19-20 yadi ... vadet] TYS 12.16 
If placed in the ascendant, Venus gives men happiness, gain, delight and honours from the king, and their family prospers.

If Saturn occupies the ascendant in the year, there is agitation of [the humours of] phlegm and wind, pains in the head and stomach, enmity with loved ones and pain in the mouth.

If Rāhu is placed in the ascendant of the year, there is pain caused by [the humour of] wind in the body, strife, loss of fortune, and evils [to] children, friends and so on.

This concludes the judgement of the first house.

\subsection{The Second House}

Next, the judgement of the second house. Concerning that, Candeśvara describes what is to be considered from the second house:

Rubies, pearls, jewels, minerals, diamonds, clothes, gold, horses and all such [things], silver and grains, buying and selling and so on are the general [significations] assigned to the second [house].

Here, if the second house should be aspected or joined by its ruler and a benefic, then there is happiness from the acquisition of rubies, pearls, jewels, diamonds, clothes, gold and so on, happiness from horses and so on, acquisition of wealth from buying and selling, gain from dealing in grains and so on. By malefics [aspecting or occupying the house] all is reversed; by mixed [planets], mixed. Next, configurations [are described] in the Varșatantra [beginning at 6.1]:

When Jupiter as ruler of the second house in the nativity occupies the second house in the year and has an itthaśāla with the ruler of the ascendant, then there is gain of wealth throughout the year; [but] if there is an isaräpha with a malefic, loss of wealth and grains.

[In Tājikayogasudhānidhi 12.6], however, Yādava describes the configuration with Jupiter occupying [rather than ruling] the second house in the nativity:

If Jupiter is in the second house in the nativity and is there again in the year, in a mutthaśila configuration with its ruler, then one should predict with certainty that there will be abundant wealth in that year. 
tājikasāre muthaśilaṃ vinaiva yoga uktaḥ |

vitteśvaro janmani devapūjyo varșe dhanastho dhanalābhakrt syāt |

varșādhināthena yutekșito vā jīvas tathā varșapatir balạ̄hyah \||

dhanapatih kurute dhanago dhanam yadi surādhipatījyasamanvitaḥ || iti |

varșatantre |

janmany arthāvalokījyo 'bde 'bdeśo balavān yadā|

tadā dhanāptir bahulā vināyāsena jāyate \|

evaṃvidho gurur dhanabhāve ced bhavati tadā viśeṣeṇottamaphalam uktam yādavena |

janane dhanadṛștike gurau śaradiśe śaradipsitam dhanam |

dhanagehagate tathā dhanair bahubhih sevya ihārthavān naraḥ \|

vāmanena tu guror dhanabhāve dṛșțiṃ vinaiva yoga uktah |

gurau varșādhipatyaṃ ca sabalatvaṃ ca bibhrati |

dhanāptir mahatì tatra varṣe bhavati niścayāt |

evamvidhe site saumye 'thavā bahudhanam bhavet ||

dhanasthāne śubhayute dhanāptir bahudhā bhavet |

nirbale pāpayukte ca dhanahānis tu jāyate \|

varșatantre |

\footnotetext{
1 yoga uktaḥ] yogoktāḥ B N; yogoktaḥ G KT 3 balāḍhyaḥ] valādyaḥ N 6 arthā] athā N \| 'bde] om. B N G 7 tadā] tada G 10 śaradīśe] dhanabhāve B N || îpsitam ] īppitaṃ N 11 -vān naraḥ] -vā bharaḥ $\mathrm{N} 12$ vāmanena] vāmane $\mathrm{G} \|$ guror] gurur $\mathrm{G}$ \| bhāve] bhāva $\mathrm{G}$ || yoga uktaḥ] yogoktāḥ B; yogoktaḥ N G K T 13 gurau] gurur B N G K T 17 jāyate] evaṃ add. B

2-3 vitte- ... balāḍhyah] TS $192 \quad 4$ dhana ... samanvitah] TS $178 \quad 6-7$ janmany ... jāyate $]$ VT $6.2 \quad 10-11$ janane ... narah. $]$ TYS 12.17
} 
In Tājikasāra [192, 178], the configuration is described without a mutthaśila:

Jupiter as ruler of the second house in the nativity occupying the second house in the year will make gain of wealth, or [if] Jupiter is joined to or aspected by the ruler of the year; likewise [if it is] ruler of the year, endowed with strength.

The ruler of the second house occupying the second house produces wealth if joined by Jupiter.

[And] in Varșatantra [6.2 it is said]:

When Jupiter aspects the second house in the nativity and, in the year, is ruler of the year and strong, then abundant gain of wealth comes about without effort.

Yādava says [in Tājikayogasudhānidhi 12.17] that if such a Jupiter is found in the second house, then results are particularly excellent:

If Jupiter aspects the second house in the nativity and rules the year, there is [gain of] the desired wealth in [that] year; and if it occupies the second house, a man becomes wealthy and attended by many riches. ${ }^{27}$

But Vāmana describes the configuration without any aspect of Jupiter on the second house:

When Jupiter possesses both rulership of the year and strength, great gain of wealth definitely takes place in that year; or if Venus or Mercury is the same, there will be much wealth. If the second house is joined by benefics, there is manifold gain of wealth; [but] if it is weak and joined by malefics, loss of wealth results.

[And] in Varșatantra [6.3-4, 5.8-9, 6.7, it is said]:

27 Although all available text witnesses of the Hāyanaratna agree on this tautological reading, independent witnesses of the Täjikayogasudhānidhi read 'attended by many persons'. The latter reading also agrees with the quotation from Samarasimpha shortly below, which is presumably the source used by the later Täjika authors. 
evaṃ yadbhāvapo janmany abde tadbhāvago guruḥ|

lagneśenetthaśâlī cet tadbhāvajasukham bhavet || tathā janușiyam paśyed bhāvam abde 'bdapo guruh | tadā tadbhāvajam saukhyam uktam tājikavedibhih $\|$ sūtau dhanapradah khețo dhanādhišaś ca tau yadi |

varșe naștau vittanāśānyanikșepāpavādadau \|

evaṃ samastabhāvānām sūtau nāthāś ca poṣakāḥ | varșe naștabalās teșām nāśāyohyā vicakṣanaih \| lagnavitteśasamyogo vittasaukhyavilāsadạ $\|$

vāmanah |

yoge lagneśavitteśor vittasaukhyaṃ na jāyate \|

atra varșatantre lagneśadhaneśayor yogah śubhaphalada uktạ̣ | vāmanenāśubhaphalada uktaḥ | tatrānayor vyavasthā | ekarāśau tayor muthaśile śubhaṃ phalaṃ mūsariphe aśubhaphalam | tad uktaṃ tejaḥsiṃhena |

svāngeśayor muthaśile sukhato 'rthaläbho

naihsvam vyaye tanupater dhanapesarāphāt || iti |

samarasiṃhaḥ |

janmani ca somajanmani șașțhapatau tatsthite ca varșāntah | laghuvittakaläbhah syād evam bhaume bhaved rogaḥ $\|$

6 nāśānyanikșepāpa-] nāśāv anyanikṣepāpa- K; nāśāv anyanikṣepa- M 9 saṃyogo] saṃyoge B N 11 lagneśa] lagnena $\mathrm{G} \|$ vitteśor] vitteśau B G; viteśo $\mathrm{N} \quad 12$ atra] ta a $\mathrm{N}$ 15 svāngeśayor] svāngeśaśayor $\mathrm{B}$ \| lābho] lābhau G 16 naị̣svaṃ] nauḥsva N; naiśvaṃ G; naissva K T M $\|$ vyaye] vyayo G; vyayau K T M 18 somajanmani] some B N \| ca $^{2}$ ] om. B N 19 vittaka] vittasya $\mathrm{G} T$

1-4 evaṃ ... vedibhiḥ] VT 6.3-4 $\quad 5^{-8}$ sūtau ... vicakșaṇaih] VT 5.8-9 9 lagna ... vilāsadạ̣] VT $6.7 \quad 15^{-16}$ svā- ... -esarāphāt] DA 18.7

9 vilāsadah] While Balabhadra's exposition confirms that this is his reading of the text, PK ad VT 6.7 confirms the alternative reading vināśadaḥ of opposite meaning. 
If Jupiter thus occupies in the year any house that it rules in the nativity, and has an itthaśäla with the ruler of the ascendant, there will be happiness arising from [the significations of] that house. Likewise, knowers of Tajjika declare that if Jupiter as ruler of the year aspects a house in the nativity [and] in the year, then happiness arises from that house.

A planet bestowing wealth [by its placement] in the nativity, and the ruler of the second house: if both are corrupt in the year, they give destruction of wealth and accusations [of not returning] the pledges of others. Likewise, if the [planets] ruling and supporting any house in the nativity have lost their strength in the year, they should be inferred by the wise to destroy those [houses].

A conjunction of the rulers of the ascendant and the second house gives happiness and delight through wealth.

[But] Vāmana [says]:

By the ruler of the ascendant and the ruler of the second house joining, no happiness from wealth results.

Here, a joining of the ruler of the ascendant and the ruler of the second house is said in the Varșatantra to give good results, [but] it is said by Vāmana to give evil results. The verdict on these two [statements is that] when they have a mutthaśila in the same sign, the result is good; when a mūsarihpha, the result is evil. That is described by Tejahsiṃha [in Daivajñālaṃkrti 18.7]:

When there is a mutthaśila between the rulers of the second house and the ascendant, there is easy gain of wealth, [but] poverty if the ruler of the ascendant has an isaräpha with the ruler of the second house in the twelfth house. ${ }^{28}$

[And] Samarasiṃha [says in the Tãjikaśāstra]:

If Mercury rules the sixth [house] in the nativity and occupies it in the year, there will be little gain of wealth; if Mars is thus, there will be illness.

28 Text witnesses G K T M omit 'in the twelfth house' and instead read 'poverty and loss'. Independent witnesses of the Daivajñălamkrti omit 'the ruler of the ascendant', leaving it implied, and read 'placed in the twelfth or sixth house'. 
yādavena tu janmani șașțhabhāvasthabudhasya yoga uktaḥ |

janane śaśije ripusthite śaradīhāpi gate 'bdake dhanam | laghu bhümisute tathāvidhe nijadhātūtthagado nirūpitah $\|$

varșeśe sati śukre dhanage saumyekșite ca bhūridhanalābhaḥ| saumye 'py evam sabale vyavasāyajñānalikhanato vittam || vittasthite gurau syāc chubhayutadrșțe dhani ca bahusevyah | muthahārāsism janmani paśyati varșe 'pi taddṛ́i viśsẹāt || mālasahame jñajīve śukre vā saumyadrșțiyuji | svakulocitam ca vittam rājyam bhūyastaram bhavati $\|$ mande ca dhanopagate dhanavyayo bhịn kṣatiś ca kāryānām | guruyukte bhrātrsukham śubhadrștyā tasya bhūtayo bhrātụ̂ \| randhre dvitīyake vā gurau ca pāpārdite bhavati hānih| haddādhipatau jīve subhadrștayute dhanaprāptị̣| viparìte dhanahānir mandasthāne gurau tathāpy evam $\|$ dvipadaṃ catuṣpadaṃ vā vicārya rāśim grahoktadhātuṃ ca| parasuhṛādigrhāṇām yathoktakāryā atho jñeyāh \| dhanalābhasya praśne lagneśenendunā ca dhananāthaḥ| kurute yadītthaśälam śubhayutidrgbhyām bhavel lābhaḥ\| lagneśadhaneśvarayor naktena ca vānyamānușāl lābhaḥ|

\footnotetext{
1 yoga uktah] yogoktah B N G K T 3 vidhe] sute B N 5 vyavasāya] vivalāya B N || likhanato] khilato BN 6 syāc chubha] syād yubha G 7 paśyati] scripsi; paśyan B NG KT M ॥ taddṛśi] tādṛśa G; tādṛ́si K T M 8 māla] mātu K T; mātuḥ M || yuji] yuti B N 11 yukte] śukre B N || śubhadṛsțtyā] śubhāgatā B N 12 dvitīyake] dviyake B N || bhavati] om. B N K T M 13 jīve] om. B N \| dṛșțayute] dṛșțayutau N; yutadṛște G; dṛștiyute K T M 15 rāśiṃ] rāśi K T M 16 parasuhṛd] paraśuhṛd N; dhanasuhṛd G K T M 17-588.3 dhana ... api] om. B N 17 lābhasya] ca add. K T M || praśne] praśna G \| dhana²] om. K T a.c. M 19 naktena] scripsi; naktam G; naktañ K T M

2-3 janane ... nirūpitaḥ] TYS $12.20 \quad$ 17-18 dhana ${ }^{1}$... lābhaḥ] Cf. PT 2.6

4 varșeśe ... lābhah] This half-stanza again has 33 morae. 8 mālasahame] G adds in the margin, seemingly as a gloss: dhanasahame. 13 jive] $\mathrm{B}$ and $\mathrm{N}$ both display a lacuna in this place.
} 
But [in Täjikayogasudhānidhi 12.20], Yādava describes the configuration with Mercury occupying [rather than ruling] the sixth house in the nativity:

If Mercury occupies the sixth house in the nativity and is placed there in the year, too, there is little wealth in [that] year; if Mars is such, disease is declared to arise from its own temperament.

[Continuing from the Tãjikaśāstra:]

If Venus, being ruler of the year, occupies the second house aspected by benefics, there is abundant gain of wealth; if Mercury is thus and strong, there is wealth from trade, knowledge and writing. If Jupiter occupies the second house, joined to or aspected by benefics, [the native] is wealthy and attended by many, particularly if [Jupiter] aspects the sign of the munthaha both in the nativity and in the year.

If Mercury, Jupiter or Venus is on the māla-sahama ${ }^{29}$ joined to the aspects of benefics, there is wealth befitting one's family community and expansion of one's dominion. If Saturn occupies the second house, there is loss of wealth, fear and failure in undertakings. If it is joined to Jupiter, there is happiness from brothers; by its good aspects, prosperity for the brother. If Jupiter is afflicted by malefics in the eighth or second house, there is loss; [but] if Jupiter as ruler of the hadda is aspected by or joined to benefics, gain of wealth. ${ }^{30}$ If the opposite, there is loss of wealth; likewise if Jupiter is in a sign of Saturn. After considering whether a sign has two feet or four feet ${ }^{31}$ and the element signified by the planets, one should understand the matters ascribed to [planets] in inimical or friendly domiciles and so on.

In a question on gaining wealth, if the ruler of the second house makes an itthaśa la with the ruler of the ascendant or with the moon, with benefics joining and aspecting, there will be gain. By a nakta

29 Arabic sahm al-māl 'lot of wealth' (discussed by that name under 4.3 and 4.6 above). While text witness G glosses mäla with the Sanskrit word dhana 'wealth, money', the fact that Balabhadra does not explain the Arabic loanword suggests that it had already gained sufficient currency in North India for him to expect his readers to be familiar with it. In modern Hindi, māl means 'goods, property, money'.

30 It is not clear what terms ( hadd $\bar{a})$ are meant. If, as is likely, this configuration derives from an Arabic source text, the word most likely refers to the terms through which the ascendant or another significator is currently directed (the qisma, making Jupiter the qāsim).

That is, whether it is represented by a human or animal image. 
yamayāyoge 'pi tathā śubhayukte vā dhane bhadram \|

krūragrahair dhanasthair dūre lābho 'nyad dāsyād aśubham |

krūramuthaśile ca tayor mriyate praștā kathamcid api $\|$

vāmanah |

gurur janmani yadrāśau tadrāśau varșalagnage |

jāyate vittanīruktvam śubhasvāmiyutekșite \|

janmany arke lagnagate 'bde dhanasthe dhanam bhavet |

gurau pāpārdite randhre dhanasthe vā nrpād bhayam |

sabale 'bdapatau jñe ca lipijñānodyamair dhanam \|

varṣatantre |

janmalagnagatāḥ saumyā varșe 'rthe dhanalābhadāh \|

yādavena tu budhasyaiva yoga uktah |

vidi janmavilagnage 'bdake dhanayāte dhanalabdhir uttamā || iti |

varșatantre |

arthārthasahameśau cec chubhair mitradrśekșitau |

balinau sukhato lābhapradau yatnād arer driśa $\|$

mitradrștyā muthaśile 'rthāngayoḥ sukhato dhanam |

tayor mūsariphe vittanāśadurnayabhìtayạ |

1 yamayā] yana K; dhana M $\|$ vā] vo G $\quad 2$ 'nyad dāsyād] scripsi; nyadā syād G K T M 3 prașțā] praștị K M 5 tadrāśau varșalagnage] varṣalagnepi tādṛśaḥ $\mathrm{G} \quad 6$ vittanīruktvaṃ] mìvitaniruktam B N 7 dhanam bhavet] dhanasambhavet G 9 'bda] tu B N 12 yoga uktaḥ] yogoktah G 14 varșatantre] om. B N G 17 'rthāngayoh] rthāṃgapayoḥ B N

2-3 krūragrahair ... api] Cf. PT $2.7 \quad 11$ janma ... lābhadāḥ] VT $6.8 \quad 13$ vidi ... uttamā] TYS $12.25 \quad 15^{-18}$ arthārtha ... bhītayah] VT 6.10-11 
between the ruler of the ascendant and the ruler of the second house, there is gain through another person; likewise in a yamaya configuration; or if the second house is joined by benefics, it is good. By malefic planets occupying the second house, gain is far away: what is more, there is evil from servitude. And if the two have a mutthaśila with a malefic, the querent somehow dies. ${ }^{32}$

[And] Vāmana [says]:

If the sign in which Jupiter was [placed] in the nativity is on the ascendant of the year, joined to or aspected by benefics and its ruler, wealth and good health result. If the sun occupies the ascendant in the nativity and the second house in the year, there will be wealth. If Jupiter is afflicted by malefics in the eighth or the second house, there is danger from the king. If Mercury as ruler of the year is strong, there is wealth through endeavours of writing and knowledge.

[And] in Varșatantra [6.8 it is said]:

Benefics occupying the ascendant of the nativity and [placed] in the second house in the year give gain of wealth.

But Yādava [in Tājikayogasudhānidhi 12.25] ascribes [that] configuration only to Mercury:

If Mercury occupies the ascendant in the nativity and is placed in the second house in the year, there is abundant gain of wealth.

[The description] in Varșatantra [6.10-11, 14-18, continues]:

If the rulers of the second house and of the sahama of wealth are strong and aspected by benefics with a friendly aspect, they bestow wealth with ease; with difficulty, if [aspected] with an inimical aspect. In a mutthaśila by friendly aspect between [the rulers of] the second house and the ascendant, wealth [comes] easily; in a müsarihpha between

32 The Arabic text by Sahl ibn Bishr on which this passage is ultimately based speaks not of the querent dying, but of a condition of poverty lasting until death. See Gansten 2014: $110 \mathrm{ff}$. 
krūrayogekșaṇāt sarvam viparītạ̣ phalam bhavet ||

vitteśo janmani gurur varșe varșeśatām dadhat | yadbhāvagas tam āśritya lābhado lagna ātmanậ \| vitte suvarṇarūpyāder bhrātrādeh sahajarkșagaḥ| pitrmātṛșamādibhyo vittaṃ suhrdi pañcame |

suhrttanayatah șașțe 'rivargād bhüribhïtidah $\|$ strïbhyo dyūne 'ștame mrtyur arthahetuh patho 'nkage | khe nrpāder nrpakulād àye 'ntye vyayado bhavet \|

yādavaḥ

tanuge sabale janau dhane śaradarke tanupetthaśālini |

śubhadrśy atha tungage svabhe bahuvittam nijavaṃśajān nrpāt \| jananābdakayor dhane tamo grasati dravyam asaumyadrgyutah \|

jīrṇatājike |

candro lagnapatir vāpi dhanapasyāgrago bhavet |

tadā na dhanalābhah syād dhanahānir bhaved dhruvam \|

dhane lagnapatir dyūne vittapo dhanaläbhakrt |

dhane śukrenduguravo yadā lābho mahāms tadā ||

cararāśau lagnagate pāpe ca samavasthite |

arthānām ādiśed dhāniṃ tatra varșe suniścitam ||

tejahsimphah |

sve 'rtho gurau januși taddrśi vā nrpādeh

prāptị̣ savāngagaśubhair dhanagaiś ca varșe \|

6 bhūri] dhāni G 8 nụpakulād] nṛkulād N 11 tungage svabhe] tuṃgagehage G K T M ॥ vaṃśajān] vamśajam G K T 12 dhane] dhana G 14 patir] pavir N \| dhana] dhadhana N || pasyāgrago] pasyāgraho B N 15 dhana $^{1}$ ] om. N || syād] om. G 16 lagna] dhana B N 17 lābho mahāṃs tadā] lābho nahis tadā K T M 21 sve 'rtho] arthe K T M || taddṛśí] tādṛśí G || nṛpādeh] ṇ̣pebde G 22 savāngaga] savīryaga B N

1-8 krūra ... bhavet] VT 6.14-18 10-11 tanuge ... ṇ̣pāt] TYS 12.30 12 jananā- ... yutah ] TYS $12.22 \quad 21-22$ sve ... varșe] DA 18.6 
the two, there is loss of wealth, misconduct, and fear. By malefics joining or aspecting, all [good] results will be reversed.

Whatever house Jupiter, being ruler of the second house in the nativity and holding rulership of the year, occupies in [that] year, it gives wealth in accordance with that: in the ascendant, [it gives wealth originating] from oneself; in the second house, from gold, silver and so on; occupying the sign of the third house, from brothers and so on; in the fourth house, there is wealth from father, mother, the earth and so on; in a friendly [sign] in the fifth, from friends and children; in the sixth, it gives grave danger from enemies; in the seventh house, from women; in the eighth, death is the cause of wealth; when it occupies the ninth, [wealth comes] from journeys; in the tenth house, from the king and so on; in the eleventh house, from a princely family; in the twelfth house, it causes loss.

[And] Yādava [says in Tājikayogasudhānidhi 12.30, 22]:

If the sun occupies the ascendant in the nativity and the second house in the year, having an itthaśâla with the ruler of the ascendant, aspected by benefics or occupying its exaltation or domicile, there is much wealth from a prince born in one's own lineage.

Răhu in the second house of the nativity and the year, joined to the aspect of malefics, devours wealth.

[And] in the Jirnatäjika [it is said]:

Should the moon or the ruler of the ascendant be placed ahead of the ruler of the second house, then there will be no gain of wealth; [rather], loss of wealth will certainly occur. The ruler of the ascendant in the second house [and] the ruler of the second house in the seventh house bring gain of wealth. When Venus, the moon and Jupiter are in the second house, then there is great gain. If a movable sign occupies the ascendant and a malefic is located [there], one should predict definite loss of wealth in that year.

[And] Tejaḥsiṃha [says in Daivajñālaṃkrti 18.6, 10, 4, 3]:

If Jupiter is in the second house in the nativity or aspects it, there is wealth: gain from the king and so on by benefics occupying the ascendant of the nativity and the second house in the year. 
saumyagraho januși pūrnabalo dhane cet tatra sthito 'bdasamaye 'pi tadā dhanam syāt | dravye ca viryayuji kim bahunā dhanaṃ syād dravyasya hānir adhame 'khilam ittham ūhyam \| bhānau nabhoyuji save ca nabhậsthite 'bde syāl lagnabhunimuthaśile vibhutā svamānāt $\|$ mando 'bdapo 'bdasamaye 'pi mrtāv asaumyadrgyuktibhān mrtikaras tanupetthaśālī $\|$

\section{uttaratantre |}

śîtāṃśulagneśvaravittanāthāh parasparam saṃyutavīkșitāś ca | dhanatrikonodayagā yadā syus tadārthalābham pravaden narāṇām || śaśān்ajīvajñasitā balạ̄̂hyyā vittāyadharmātmajakanțakasthāh | svoccādigāḥ syur na ca pāpayuktāḥ kurvanti lābham pracuraṃ suśīghram || śîtāmśuvitteśvaralagnapānām kambūlayoge pracurārthalābhaḥ| lagneśavitteśvarayoś ca naktayoge 'nyamartyād dhanam eti prcchakaḥ| vittam ca vindyād yamayākhyayoge dvayoś ca pāpārditayor na vittabhāk $\|$ krūrair dhanasthaị śubhadrsțtayuktair dūre cirād alpadhanasya lābhaḥ| pāpekșitair vittagataiś ca pāpair dhanasya nāśaś cirasamcitasya \| lagneśavittādhipatītthaśâlo yasmin hi bhāve śubhavīkșitah syāt | tanvarthabhabhrātrsuhrtsutārijāyāsu taddvārata eti lābham \| dharme 'tha dharmād gagane kșitišsall lābhe svamitrād vyayage vyayādiḥ|

3 bahunā] scripsi; bahuthā B; bahudhā N G K T M $\quad 4$ 'khilam] likhim N $\quad 5$ save ca] ca sarva B N; sicecca K T M 6 bhun்] yug K T M \| muthaśile] muthaśilair B N 8 yukti] bhukti K T M \|| bhān்] bhāk bhū N 12 kaṇțakasthāḥ] kaṃrakasthāḥ N 13 svoccādigāḥ] ccādigāḥ N 14 vitteśvara] vitteravara N \| pracurārtha] pracurortha K T; pracuro 'rtha M 16 vindyād] vidyā B N || yoge] yoga T 20 arthabha] artha B N \| sutāri] sutāyah ri G || dvārata] dvāratva N 21 gagane] gamane B N; gagana T || lābhe] lobhe N \| vyayage] vyayago B N || vyayādiḥ] vyayādeḥ B N G

1-4 saumya ... ūhyam] DA 18.10 $\quad 5^{-6}$ bhānau ... mānāt] DA $18.4 \quad 7-8$ mando ... -etthaśālī] DA 18.3

3 bahunā] The emendation is supported by MSs DA1, DA3. 
If a benefic planet is in the second house of the nativity with full strength and occupies it at the time of the year as well, then there will be wealth. What point is there in saying more? If the second house is endowed with strength, there is gain of wealth; loss of wealth if it is weak. Thus all things should be judged.

If the sun joins the tenth house in the nativity and should occupy the tenth house in the year, in a mutthaśila with the ruler of the ascendant, there is greatness [arising] from [the native's] own worth.

Saturn as ruler of the year and [placed] in the eighth house at the time of the year with malefics aspecting or joining it, and in an itthaśāla with the ruler of the ascendant, brings death.

[And] in the Uttaratantra [it is said]:

When the moon, the ruler of the ascendant, and the ruler of the second house, joined to or aspecting each other, occupy the second house, a trine, or the ascendant, then one should predict gain of wealth for men. Should the moon, Jupiter, Mercury and Venus be endowed with strength, occupying the second, eleventh, ninth or fifth house or an angle and their exaltations and so on and not joined to malefics, they make plentiful and very quick gain.

In a kambüla configuration between the moon, the ruler of the second house, and the ruler of the ascendant, there is plentiful gain of wealth. In a nakta configuration between the ruler of the ascendant and the ruler of the second house, the querent obtains wealth through another person. He will also find wealth if the two have a yamaya configuration, [but] if they are afflicted by malefics, he does not get wealth.

By malefics occupying the second house aspected by or joined to malefics, there is gain of little wealth, far away and after a long time; but by malefics occupying the second house aspected by [other] malefics, there is loss of long-accumulated wealth.

Should the ruler of the ascendant and the ruler of the second house have an itthaśála in any house, aspected by benefics, [then] in the houses of the body, wealth, brothers, friends, children, enemies, and wife, ${ }^{33}$ [the native] has gains by means of those [persons and things signified]. In the ninth house, [he has gains] from piety; in the tenth house, from the king; in the eleventh house, from his friends; in the 
lagneśavittādhipatītthaśāle randhre dhanāptir vadhabandhayuddhāt || vitteśvaro lagnagatạ kuțumbe lagneśvara ḥ syād dhanado narānāam | lagnārthapau vittagatau vilagne vittodayeśau sukhavittadau stah \| lagneśavittādhipatī vilagne nirīkșyamānan gurucandramobhyām | śubhau ca tau vìryayutau viśeșāl lābham prabhūtam kuruto narāṇām || śitāṃśuvitteśvaralagnanāthà vittasthitāh syur balino viśeșāt | praștuḥ prakuryuḥ pracurārthaläbham vitteśajīvaḥ sita indujo vā $\|$ pūrnạ śaśāinko vrșakarkam āśrito nirīkșito vā sahitah śubhagrahaị | pāpair vihīno gaganārthalābhagah praștuh prabhūtārthasukhāspadapradah \| devejyacandrātmajabhārgavānāam eko 'pi tunge svagrhe balāḍhyah | lagne dhane karmaṇi vā trikoṇe sthitạ prakuryāt sahasārthaläbham \|

atha dhanabhāvasthitānāṃ sūryādīnāṃ phalāni padmakośe |

kuțumbād virodho nrpād bhïtikaștạ̣

dhanārtir dhanasthe ravau mānavānām |

paśūnām prapịdodare cāpadaḥ syuḥ

sa saumyānvito dravyalābham karoti \|

kuṭumbājjayam mitrapakṣāc ca lābham

dhanāḍyam dhanasthah śaśāinkah prakuryāt |

ripūnāạ vināsaṃ tathā netrapịdạ̣̄

bhaved abdamadhye nrpāt saukhyakārī $\|$

dhanastho dharanyātmajo dravyaläbham

śiro'rtim janānām virodham karoti |

tathaudaryavahner bhayam śokamohau

kalatre 'kșirogam karotīha varșe \|

\footnotetext{
1 vittā-] vicā- $\mathrm{M} \|$-îtthaśāle] -îtthaśāli G || vadha] dhana M $\quad 2$ dhanado] dhanage K T M 3 vilagne] om. G || staḥ] saḥ B 4 nirīkṣyamāṇau] nirīkṣamāṇau N $\quad 5^{-6}$ viśeșāl ... balino] om.KTM 8 āśrito] āśritaḥ M 9 vā sahitaḥ] savāhitaḥ N \| śubha] śubhair G 10 lābhagaḥ] lābhaḥ B N G 11 -āspada] -āspadaḥ B N 12 balạḍhyaḥ] balāḍhye B N 13 lābham] lābhạ̣ B N 14 dhana] dharma M 16 ārtir] ārtiṃ G 17 prapị̄odare] prapīrodaye N 2o śaśānkaḥ] prakuḥ add. $\mathrm{N}$

15-18 kuṭumbād ... karoti] TPK $1.2 \quad$ 19-22 kuṭumbāj ... kārī] TPK $2.2 \quad 23^{-26}$ dhanastho ... varșe] TPK 3.2

3 vilagne] G displays a lacuna in this place.
} 
twelfth house, there is loss and so on. If the ruler of the ascendant and the ruler of the second house have an itthaśāla in the eighth house, there is gain of wealth from killing, capturing, and fighting.

The ruler of the second house occupying the ascendant [or] the ruler of the ascendant [placed] in the second house will give men wealth; the rulers of the ascendant and of the second house occupying the second house, [or] the rulers of the second house and of the ascendant [placed] in the ascendant, give happiness and wealth.

The ruler of the ascendant and the ruler of the second house [placed] in the ascendant, being aspected by Jupiter and the moon, and particularly [if] the two [rulers are] benefic and endowed with strength, make abundant gain for men. Should the moon, the ruler of the second house and the ruler of the ascendant occupy the second house, particularly [if] strong, they bring about plentiful gain of wealth for the querent [if] the ruler of the second house [is] Jupiter, Venus or Mercury.

The full moon resorting to Taurus or Cancer, aspected by or joined to benefic planets, free from malefics and occupying the tenth, second or eleventh house, bestows abundant wealth, happiness and rank on the querent. Even one among Jupiter, Mercury and Venus [placed] in its exaltation or domicile, endowed with strength, and occupying the ascendant, second or tenth house, or a trine, will bring about sudden gain of wealth.

Next, the results of the sun and other [planets] occupying the second house [are described] in [Tājika] padmakośa [1.2, 2.2, 3.2, 4.2, 5.2, 6.2, 7.2, 8.2]:

When the sun is in the second house, men will have strife on account of their household, the evil of danger from the king, injury to wealth, suffering to cattle and pains in the stomach; [but] if it is joined to benefics, it makes gain of goods.

Occupying the second house, the moon will bring triumph on account of the household, rich gains from friends, destruction of enemies, [but] also ailments of the eyes. In that year it makes happiness from the king.

Occupying the second house, Mars makes gain of goods, headache, strife with men, danger from the stomach and fire, ${ }^{34}$ grief and confusion, and eye disease to the wife in this year. 
dhanasthah sutaḥ syād yadā śîtaraśmer bhaved dravyalābhậ kuṭumbājjayaś ca | ripor nāsanam mānakìrtyor hi lābhặ pratișthādhikā hāyane syāt sukham ca $\|$ kuțumbarāśau ca gate surejye dhanādibhogāl labhate manuṣyah | catuṣpadānām ca samāgamaḥ syāt taddhāyane bhūpajanāc ca lābhaḥ || dhanasthe kavau dhānyaläbho dhanāptir bhaven mlecchajāteh sukham sampadām ca| naro rājatulyo bhavaty atra varșe paśūnām hayānām gṛhe syāt sukhaṃ ca \| divānāthaputro dhanastho dhanānām vināśam vidhatte kuțumbād virodham | prakuryāc ca netrodareșu prapị̣̂ạm kaphārtiś ca varșe bhavet sarvadaiva \| janāpavādam ca kuțumbagaś cet tamas tathā bhūpabhayam karoti | netrodaravyādhibhayārtidoṣād dhanāpahāram ca bhayam tathābde \|

manitthah |

ripurājānalaiś caurair vivādaṃ vibhavaryayam | kuțumbakalaham varșe dvitīyo bhāskaro yadi $\|$ iștasthānagatam saukhyam dhanāptih śvetavastutaḥ| śarīe param ārogyam dvitīye rajanīkare \| vahnicauranrpādibhyo bhayam vā vibhavakșayam | driśo ruk kāminīkaștam dhanasthe dharaṇisute \| śarīram nirujam nityam dravyalābho nrṇām bhavet | iștasvajanajam saukhyam rauhineye kuṭumbage || dhanaläbham tathārogyam pramodo bandhuvargatah | pracandaih sadrśam bhogam devejye dhanage bhavet \|

1 dhanasthaḥ] dhanastho G 3 kīrtyor] kāṃtyor G 6 samāgamaḥ] samā N 8 bhaven] bhaket N \| sampadāṃ ca] samppadāni B N 21 śarīre] scripsi; śarīraṃ B N G K T M || param ārogyaṃ] pațam ārāgyam B N 24 śarīraṃ] śarīre B N G \| nụnāṃ bhavet] bhaven nụṇām K T M 27 devejye] devejyo K T M $\|$ dhanage] dhanago K T M

1-4 dhanasthah ... ca] TPK 4.2 $5^{-6}$ kuțumba ... lābhah] TPK 5.2 7-10 dhanasthe ... ca] TPK 6.2 11-14 divā ... sarvadaiva] TPK 7.2 $15^{-16}$ janā- ... tathābde] TPK 8.2 
When Mercury should occupy the second house, there will be gain of goods and triumph on account of the household, destruction of enemies, gain of honour and renown, great eminence and happiness in [that] year.

And if Jupiter occupies the sign of the second house, a man gains wealth and other pleasures; there will be acquisition of quadrupeds in that year, and gain from royal persons.

If Venus occupies the second house, there will be increase of grains and gain of wealth from those of foreign birth and happiness from riches; a man becomes equal to a king in this year, and there will be happiness from cattle and horses in his house.

Occupying the second house, Saturn gives destruction of wealth, strife on account of the household; it will bring about suffering of the eyes and stomach, and there will always be ailments from [the humour of] phlegm in [that] year.

If occupying the second house, Rāhu makes slander by [common] people and likewise danger from the king; from the ills of pain and danger of illness of the eyes and stomach [it makes] expense of wealth and danger in [that] year.

[And] Manittha [says]:

If the sun is [placed in] the second [house, it makes] disputes, loss of fortune, and quarrels in the household in [that] year through enemies, the king, fire and robbers.

If the moon is in the second, there is happiness relating to loved ones, gain of wealth from white articles, and excellent health in the body.

If Mars occupies the second house, there is danger from fire, robbers, the king and so on, loss of fortune, illness of the eyes, and evil to one's wife.

If Mercury occupies the second house, men will have constant good health in the body, gain of goods, and happiness derived from loved ones and one's own people.

If Jupiter occupies the second house, there will be gain of wealth and good health, rejoicing in the company of kinsmen, and objects of pleasure such as white oleander. 
dhanalābham suhṛdvrtteḥ strīsukham śatrusaṃkșayam |

kāntivrddhir nṛnām dehe daityejyo dhanago yadi $\|$ püdā vaktre tathā netre dhananāso nrpād bhayam | putrajāyādikaștam ca dvitīye ravinandane \| dhanavyayam anārogyaṃ cintā vastyādipị̣anam | vaktralocanapīdā ca dhanasthe siṃhikāsute \|

iti dhanabhāvavicāraḥ ||

atha sahajabhāvavicārah | tatra sahajabhāve kiṃ cintanīyam ity uktạ̣ cạ̣deśvareṇa |

śūrānujakṣetrasamṛddhilābhaṃ bhṛtyādidāsībhațakarmakartuḥ| yātrādi cintā vinayam samagram paryāyam etat kathitam tṛtīye \|

atrāpi saumyasvāmiyutadṛșțau pūrvavad vicāraḥ | vāmanaḥ |

sūrye site vā varșeśe sahaje bhrātṛtah sukham |

śubhadrște 'tha taị sārdham kalahah pāpavīkșite \|

śukre dagdhe jhakațakas taị sārdham kaștadam phalam |

jōve sahajage saukhyam sodarāṇām prajāyate \|

atra jīve tritīyabhāve punar ākulatā ca sodarāṇām ca iti samarasiṃhoktam dușțaphalam nirbalagurau jñeyam | uktaṃ ca yādavena |

1-2 dhana ... yadi] om. B N 1 vṛtteḥ] vṛttiḥ K T; vṛddhiḥ M 5 cintā vastyādi] ciṃtāvasthādi K T M 6 vaktra] vaktre K T M \| dhanasthe] dhanastho K 7 iti] bha add. N \| bhāvavicāraḥ] bhāvaḥ B N 8 cintanīyam ity] ciṃtanīmāty N 10 dāsī ... kartuḥ] mārgạ̣ ca vade prakartuh K; mārgaṃ ca vadec ca kartuḥ T M 11 vinayaṃ] vilayaṃ B N; ninayam T M 12 dṛșțau] dṛ́sau K; dṛśaiḥ T M || pūrvavad] pūrvavid N || vāmanaḥ] nāmataḥ K 13 varșeśe] varșeśaṃ K T M 14 dṛșțe] dṛșța T \|| 'tha taih] dhanaị̣ K T M \|| kalahaḥ] kattaruh K 15 śukre] śukra B N || jhakațakas] jñakaṃțakastraiḥ K 17 punar] yutar K T; pitur M \| ca $^{1}$ ] om. KM || ca iti] veti G || siṃhoktaṃ] sitoktam K 18 dușța] dṛsța KM || gurau] guror K T M \| jñeyam] jñeyaḥ K T || uktaṃ ca] tad uktaṃ K T M \| yādavena] vadanena K 
If Venus occupies the second house, men have gain of wealth from the affairs of friends, happiness from women, destruction of enemies, and increase in the beauty of the body.

When Saturn is in the second, there are ailments of the mouth and eyes, loss of wealth, danger from the king, and evils to children, wife and so on.

When Rāhu occupies the second house, there is loss of wealth, poor health, anxiety, illness of the abdomen and so on, and ailments of the mouth and eyes.

This concludes the judgement of the second house.

\subsection{The Third House}

Next, the judgement of the third house. Concerning that, Candeśvara describes what is to be considered from the third house:

Valour, siblings, gain of land and prosperity, ${ }^{35}$ servants and so on, servant-girls, mercenaries and labourers, travel and so on, thought ${ }^{36}$ and conduct: these are all declared [to be significations and therefore] synonyms of the third [house].

Here, too, in the case of a benefic and the ruler [of the house] joining or aspecting [it], judgement [should be made] as before. [And] Vāmana [says]:

If the sun or Venus is ruler of the year [and placed] in the third house, aspected by benefics, there is happiness from brothers, but quarrels with them if [the ruler of the year is] aspected by malefics. If Venus is burnt, there is conflict with them, an evil result. If Jupiter occupies the third house, happiness from siblings results.

On this matter, the evil result stated by Samarasiṃha [in the Tãjikaśāstra] 'And if Jupiter is in the third house, again there is agitation among brothers' should be understood [to apply] when Jupiter is weak. And Yādava says [in Tājikayogasudhānidhi 12.33]:

35 Or 'land and gain of prosperity', or even 'land, prosperity and gain'.

36 Cintā 'thought' also has the more specific meaning 'worry, anxiety', and text witnesses $\mathrm{B} \mathrm{N}$ read 'the vanishing of anxiety'. 
dhișaṇe sabale samādhikāre sahajasthe sahajotthasaukhyam asmin | aśubhākșiyute vinaștadagdhe sahajād vyākulatātiduḥhitā ca \|

bhrātrsaukhyam vilagnābdanāthayuksahajeśvare |

vidhau sahajage sāre bhrātṛnām arucir bhavet ||

tatra sthito budhạ saumyekșito 'py anujavrddhikrt |

bhrātrsadmeśvare naște 'nujanāśas tadā bhavet | tasmimiś cābhyudite vïryayute bhrātrsukham bhavet \|

tejaḥsiṃhạ̣|

lagnābdabhunimuthaśile sahaje tadīse

dūre 'pi sodaragaṇe yutisaukhyadāȳi

vādas tu mūsariphato 'tra mitho 'śubhekșe

sāre vidhau sahajage sahajāturatvam \|

janmābdayos tu sabalo 'nujavrddhido jña

evam gurau sahajage 'khilabandhuyogah $\mid$

yukte nijeśasahameśadríarddhayah syur

bhrāturvyayo 'śubhayute tu nijeśanāsāa $\|$

aste trtīyapatitas tanupe 'bdape $v \bar{a}$

vādo mithas tv aparabhāvapater apüttham |

bhrātrīśvare januși taddrśsi cāpi varșe

tatsthe subhekșitayute sahajeșu saukhyam \|

1 asmin] asthin $\mathrm{N} \quad 2$ aśubhākṣi] aśubhekșita B N M; aśubhākṣita K T || yute] yukte $\mathrm{K} \mathrm{T}$; yug M || sahajād] sahaja B; sahajaṃ N; sahajā K T 4 sahajage] sahajaro N; saduge K $\quad 5$ budhah] vadhah K M || 'py anuja] nuja G K T M \|| vṛddhi] viṿ̛ddhi G K T M 6 'nujanāśas] nujānāśas K; rujo nāśas M 7 cābhyudite] cāpyadite K; cāpy udite T M \| vīrya] vīrye $\mathrm{K}$ TM 9 tadīśe] tadīśo $G \quad 10$ dūre 'pi] saumyā hi K T; dūre hi M \| dāyī] dāyi K; dāpa M 11 mūsariphato 'tra] mūsariphah tatra B N; mūsariphi tatra G 13 janmābdayos] janmābdapos M \|| 'nuja] naja K; na ca T M \| vṛddhido jña] scripsi; vṛddhido jño B N G; vṛddhirājño K T; vṛddhirājño hy M 14 sahajage] sahajago $G \quad 15$ sahameśadṛśarddhayah] scripsi; sahame sadṛsāārddhayah B N; sahameśadṛsāarddhayaḥ G; sahame sadṛsáābdapaḥ K T M 16 bhrātur] bhrātar M \| vyayo] yamī K T M 18 mithas tv apara] mithostva'para G; mithastapara K; mithaḥ svapara M 19 taddṛ́i] scripsi; tādṛśi B N G K T M \| cāpi] vāpi K T M

1-2 dhiṣaṇe ... ca] TYS 12.33 9-12 lagnā- ... -āturatvam] DA 19.2 13-20 janmā- ... saukhyam] DA 19.4-5

8 tejahsiṃhah] At this point, K T M add a somewhat unmetrical stanza not found in independent witnesses of the DA: svasvāmisaumyekșita (-saumyekșiti $\mathrm{K} \mathrm{T}$ ) bhrātrgehe lagnādhināthena nirīkșito (nirīkșitau K T) vā| kendre trikonāyagate tadīse sukham samutthair bahulam prakalpyam (ahulam akalpam K; ahalam prakalpam T) || 19 taddṛsíi] The emendation is supported by MSS DA1, DA3. 
If Jupiter, being strong and having authority in the year, occupies the third house, happiness arises from siblings in this [year]. If it is joined to the aspects of malefics, corrupt or burnt, there is agitation and great unhappiness from siblings.

[Continuing from Vāmana:]

There is happiness from brothers if the ruler of the third house is joined by the rulers of the ascendant and of the year. If the moon occupies the third house along with Mars, there will be dislike among brothers. Mercury placed there and aspected by benefics makes increase of siblings. If the ruler of the lot of brothers is corrupt, then there will be destruction of brothers; but if it is [heliacally] risen and endowed with strength, there will be happiness from brothers.

[And] Tejaḥsiṃha [says in Daivajñālaṃkrti 19.2, 4-5]:

If, in the third house, its ruler has a mutthasila with the ruler of the ascendant or of the year, it grants the happiness of meeting even if [the native's] siblings are [settled] far away; but from a müsarihpha here there are disputes among them if malefics aspect. If the moon occupies the third house with Mars, there is suffering to siblings.

Being strong in the nativity and the year, Mercury [in the third house] gives increase of siblings; likewise, if Jupiter occupies the third house, all kinsmen come together. If it ${ }^{37}$ is joined by the aspect of its own ruler and the ruler of the sahama [of brothers], there are riches for the brother, but loss by the corruption of its own ruler if it ${ }^{38}$ is joined to malefics. If the ruler of the ascendant or the ruler of the year is in the seventh house from the ruler of the third [house], there are disputes among them; so also for the ruler of [any] other house. If the ruler of the third house aspects it in the nativity and occupies it in [the revolution of] the year, aspected by or joined to benefics, there is happiness among siblings.

37 Presumably the third house is meant, although grammatically the reference appears to be to Jupiter.

38 Again, the reference is not entirely clear. 
samarasiṃhạ |

sahajapatau sahajasthe 'dhikāravati lagnapasya muthaśilini | varșapater vā sodarayogāt prītir dvayoh saukhyam \|

varṣatantre |

krūresarāphe kalahaḥ śanau bhaumarkṣage rujaḥ|

jñarkṣe 'srijy anuje māndyam vadet sahajage sphuțam \|

krūresarāphe krūradṛśā lagneśābdeśayoḥ sahajeśenesarāphayoge |

mandarkșage 'ș̣i budhe kujarkṣe sahaje śubhaih |

yutekșite sodarāṇām mithaḥ sakhyam sukham bahu \|

vìryānvitendugrhago bhrgujo 'dhikārì

sūtyabdayoḥ sahajabandhugañasya vrddhyai \|

atra tejaḥsiṃhena grahasthānāny uktāni |

sthāne kujasya tu śanau sahajārtidauhsthye

jñasthānage 'nujabhayam sahaje mahïje |

sthānam gate ca śaśino balino 'bdakāle

sūtau ca bandhusahajopacayādi śukre || iti |

jīrṇatājike |

2 'dhikāravati] dhikāravartti K T M 3 varșa] varșe B 4 varșatantre] om. B N $\quad 5$ krūresarāphe] krūresarāphaṃ T || rujạ̣] kujaḥ N; guruh G T 7 krūresarāphe] krūresarāphaṃ K T M 8 mandarkșage] maṃdarkșe B N \|| 'ș̣ji budhe] sṛjavidhe K; mṛtibudhe M 9 sakhyaṃ] saukhyaṃ G K T M || sukhaṃ] om. K M 11 abdayoḥ] abdapoḥ M 12 graha] grahānāạm K T M $\quad$ 13-16 -sya ... -cayādi] om. T a.c. M 13 dauhsthye] dausthaṃ K 14 'nuja] ranuja T 15 sthānaṃ gate] sthānāṃgate K; sthānaṃga T || balino] om. N 16 sahajopacayādi] sahajo yatra pādi $\mathrm{K}$

5-6 krūresarāphe ... sphuțam] VT 7.5 $\quad 8-9$ mandarkṣage ... bahu] VT 7.6 $10-11$ vīryā- ... vṛddhyai] VT 7.7 13-16 sthāne ... śukre] DA 19.3

13-16 -sya ... -cayādi] T adds the omitted passage in a different hand at the bottom of folio $\mathrm{U} 8^{\mathrm{v}}$. 
[And] Samarasiṃha [says in the Tājikaśāstra]:

If the ruler of the third house, occupying the third house, has authority [in the year and] has a mutthaśila with the ruler of the ascendant or the ruler of the year, there is affection from a meeting of siblings, and happiness to both.

[And] in Varșatantra [7.5 it is said]:

If there is a malefic isarāpha, there is conflict; if Saturn occupies a sign of Mars, ailments; if Mars is in a sign of Mercury, one should predict ill health to a brother, certainly if it occupies the third house.

'If there is a malefic isarāpha' [means] if the ruler of the ascendant and the ruler of the year have an isaräpha configuration with the ruler of the third house by a malefic aspect. [Continuing from Varșatantra 7.6, 7:]

If Mars is in a sign of Saturn [or] Mercury in a sign of Mars in the third house, joined to or aspected by benefics, there is mutual friendship and much happiness.

Venus, occupying the house of the moon endowed with strength ${ }^{39}$ and having authority in the nativity and the year, makes for increase among siblings and kinsmen.

Concerning this, Tejahsiminha describes the places of the planets [in Daivajñālaṃkrti 19.3]:

If Saturn is in the place of Mars, there is injury and uneasiness to siblings; if Mars in the third house occupies the place of Mercury, there is danger to siblings. If Venus occupies the place of the strong moon at the time of [the revolution of] the year and in the nativity, there is increase of kinsmen and siblings and so on.

[And] in the Jirnatäjika [it is said]:

39 It is not clear whether Venus or the moon should be strong. 
janmalagnābdalagneśau budhaśukrau balānvitau | sahaje sahajāt saukhyam gurau caivam phalam vadet \| vikramas tatpatir vāpi yadi saumyagrahekșitah | nirākulas tadā bandhur duḥsthaḥ krüragrahe matạ̣ \| ripau vikramapas tișthet tadgṛhe ripurāsiipạ̣| bhrātrpe krūradrște vā bhrātā rogena pịditậ \| sahajādhipatị̣ kendre balì sahajasaukhyadah | sahaje pāpasamyukte svāmyadrște 'nuje bhayam | evam ca bhrātṛsahame phalam jñeyam prayatnatah $\|$ adhikārī bhrgur varșe save vā candrasamyutaḥ| varșe syād yatra kutrāpi sahajānām sukhapradaḥ \|

\section{yādavaḥ |}

aśubhākșiyute śarajjabandhau sati dagdhe svapatau na tena drșțe | jananissahameśadrșțihīne vyasanam bandhușu nūnam atra vācyam || janibandhupatau samāvinaște jananīsadmapatāv apīha naște | khalakhecarayogadrșțiyukte sahajānām ca bhaved vināśa ugrah \| janibandhugate 'bdabandhuge 'smin sabale 'ñgābdapatīthaśālayoge | paradeśagabandhuyogasaukhye khaladrștyā musarīphake kalis taih \|

\footnotetext{
1 balānvitau] balānvite K T 4 matah] yataḥ G; sthitaḥ K T M $\quad 5$ vikramapas] vikramayams M 6 bhrātṛpe krūradṛșțe] bhrātṛpaidaradṛsțair B; bhrātṛpaidarașțair N 10 save] sarvair B N; sarve G p.c. K T M 11 varșe] varșo G 13 aśubhākṣi] aśubhekșita B N M; aśubhākșita K T || śarajja] saroja K T M 14 bandhușu] vuvaṃdhuṣu N || nūnam] nūtanam B 15 jani] janani B || apīha] api B N 16 yukte ... ugraḥ] scripsi; hīne vyasanaṃ bạ̣dhuṣu ugra eva vācyaḥ B N G; hīne vyasanaṃ bandhuṣu ugra eva vācyaḥ K T; hīne vyasanaṃ bandhuṣu ugram eva vācyam M 18 kalis taiḥ] valī staị̣ K; kātostaih T; balis taih M

13-18 aśubhākṣi ... taiḥ] TYS 12.37-39

16 yukte ... ugrah] The emendation is supported by MSs TYS1, TYS 3 . From the unlikely sense of the passage as given (in addition to the metrical and grammatical irregularities), the version of the HR appears more likely to be an early scribal error than the version used by Balabhadra. Note the similarities with the preceding stanza.
} 
[If] Mercury and Venus in the third house, endowed with strength, rule the ascendant of the nativity and the ascendant of the year, there is happiness from siblings; and if Jupiter is such, one should predict the [same] result. If the third house or its ruler is aspected by benefic planets, then [the native's] kinsman is untroubled; if an evil planet [aspects], he is said to be uneasy.

Should the ruler of the third house be placed in the sixth house [and] the ruler of the sixth house [be placed] in its house, ${ }^{40}$ or if the ruler of the third house is aspected by malefics, [the native's] brother is afflicted with illness.

The ruler of the third house strong in an angle gives happiness from siblings; if the third house is joined by malefics and not aspected by its ruler, there is danger to a sibling. Thus, too, one should carefully understand the result of the sahama of brothers. Wherever Venus should be in the year, conjunct the moon and having authority in the year or in the nativity, it gives happiness to siblings.

And Yādava says [in Tājikayogasudhānidhi 12.37-39, 41, 32]:

If the third house $\mathrm{e}^{41}$ arising from the year is joined to the aspects of malefics, its ruler being burnt [and the house itself] not aspected by it and bereft of the aspect of the ruler of the sahama of the mother, misfortunes to kinsmen is certainly to be predicted in this [year]. If the ruler of the third house ${ }^{42}$ in the nativity is corrupt in the year, and the ruler of the lot of the mother, too, is corrupt here, joined to the aspect or conjunction of malefic planets, there will be a terrible destruction of siblings. If this [planet] ${ }^{43}$ occupies the third house of the nativity and the third house of the year, ${ }^{44}$ strong and in an itthaśa $a$ la configuration with the ruler of the ascendant or the year, there is reunion with

40 That is, in the third house.

41 The translation is somewhat uncertain: bandhu 'kinsman, friend' is typically a designation of the fourth house in Indian astrology, but, as seen from the foregoing quotations, Tajika sources also give this signification to the third house. Appearing in the context of a discussion of the third house, bandhu does seem more likely here to refer to that house, and I have translated it accordingly; but the question is made even more problematic by the lot of the mother then being brought up, as sources are unanimous in assigning the mother to the fourth house.

42 Again, bandhu.

43 Presumably the planet last mentioned, that is, the ruler of the lot of the mother.

44 Again, 'the third house' is bandhu (both occurrences). 
j̄̄ōspade 'bde sahaje surejye balotkațe bandhusutādiharșāḥ | sakrūrayor bandhubhasadmanor vā dagdheśayoh syād vyasanāptir eșām \| sahajādhipatau ca kendrage sahaje vā sahajāt sukhaṃ pradiștam | savabandhusamāngasaumyakhețādhikrtau bandhujasaukhyam asya varșe | sahajasya tu saumyapāpayogāt sahameśe saśubhe 'pi saukhyam evam \|

uttaratantre |

duścikyanāthah sahajam prapaśyet saumyās tritīyạ sahajeśvaram ca| paśyanti nānye tv aśubhās tadāsya svasthāh pravācyāḥ khalu bāndhavāé ca șaștheśaduścikyapatītthaśāle șașțhe sthite vā sahajeśvare ca| tritīyage șașthapatau ca pāpe krūrekșite vā sahajā gadārtāḥ \|

atha sahajabhāvasthitānāṃ sūryādīnāṃ phalāni padmakośe |

tṛtīyago 'rko 'pi sahodarāṇām pị̂āạ karoty eva hi varșamadhye | parākramam rājakrpām ca lakșmīm ripukșayam kāntivivardhanam ca \| tritīye sthitaḥ siitaraśmir yadā syāt tadā sodarānāạm bhavet saukhyakārī | dhanāptim ca punyodayam guptasaukhyam pratișthāvivorddhim karotīha varșe \| tritīyasthite kșmāsute bāndhavānām bhaved angakaștam sukham vāhanānām | ripūnāịn vināśas tathā dravyalābho nrrpān mitrapakșājjayo hāyane 'smin $\|$

1 'bde] om. G || sutādi] sukhādi BNG 2 bandhubha] bandhu BN || sadmanor] sadmayor K T $\quad 3-5$ ca ... tu] om. B N 4 sava] sa ca K T M 7 duścikya] dyūścikya K \| sahajaṃ] sahaje B N 9 nānye] nānyais $\mathrm{G} \quad 10$ bāndhavāś] saṃdhanaś B N 11 duścikya] vṛścikya K \| șașțhe] șașṭha G p.c. \| ca] vā K T M 13 sthitānāṃ] sthināṃ B || phalāni] om. G 15 rāja] rājya $\mathrm{G} \|$ krpaāṃ] kriyāñ K T M 16 tṛtīye] tṛtīya K T M 20 sthite] sthito G \| kṣmāsute] kṣmāsuto G 22 tathā] tadā B N G 23 pakṣāj] pakṣāñ T

1-2 jīvāspade ... eșām] TYS $12.41 \quad 4-5$ sava ... evam] TYS 12.32 $14-15$ tṛtìyago ... ca ca TPK $1.3 \quad 16-19$ tṛtīye ... varșe] TPK $2.3 \quad 20-23$ tṛtīya ... 'smin] TPK 3.3

1 'bde] G displays a lacuna in this place. 
kinsmen gone abroad and happiness; [but] in a müsariḥpha by malefic aspect, there is quarrel with them.

If the third house in the year is a place of Jupiter, and if Jupiter is endowed with strength, there is joy from kinsmen, children and so on; [but] if the sign of the third house and the $\operatorname{lot}^{45}$ are joined by malefics or their rulers are burnt, they will suffer misfortune.

If the ruler of the third house occupies an angle or the third house, happiness from siblings is predicted. If a benefic planet has authority over the third house ${ }^{46}$ of the nativity and the ascendant of the year, happiness from kinsmen arises for him in [that] year. When the third house is joined by [both] benefics and malefics, if the ruler of the sahama is joined by a benefic, there is likewise happiness.

[And] in the Uttaratantra [it is said]:

Should the ruler of the third house aspect the third house, benefics [aspect] the third and the ruler of the third house, and no other, malefic [planets] aspect, then the kinsmen of this [native] should be declared to be in good health. If there is an itthaśäla of the ruler of the sixth and the ruler of the third house, or if the ruler of the third house occupies the sixth, or the ruler of the sixth occupies the third, being malefic or aspected by a malefic, siblings are afflicted with illness.

Next, the results of the sun and other [planets] occupying the third house [are described] in [Täjika] padmakośa [1.3, 2.3, 3.3, 4.3, 5.3, 6.3, 7.3, 8.3]:

Occupying the third [house], the sun makes suffering for siblings in [that] year, [but also] valour, royal favour, riches, destruction of enemies and increase in beauty.

When the moon should be placed in the third, then it will make happiness for siblings; it makes gain of wealth, dawning of fortune, secret happiness and increase of eminence in this year.

If Mars occupies the third, there will be bodily ills to kinsmen, happiness from vehicles, destruction of enemies, gain of goods, and triumph on account of the king and friends in this year.

45 Again, 'the third house' is bandhu. The lot is presumably that of the mother.

46 Again, bandhu. 
śaśisutaḥ sahaje yadi saṃsthitaḥ sakalatāpavināśakaras tadā| bhavati mānavivrddhir atho yaśas tanusukham ca karoti dhanāgamam || tritīyasaṃsthah surarājamantrī bhüpāj jayaṃ kìrtivivardhanam ca | sasyāmbarānāạn ca tathā dhanānām karoti vṛddhim mahatīm ca varșe \| bhrgus trtī̄yo hi sahodarānāạn sukham prakuryād vividhaih prakāraih | arthāgamam kāntivivardhanam ca janopakāram ca karoti varșe \| ravisuto bhavatīha tritīago ripuvināśakaro hi dhanapradạ̣| bhavati bhūdhanalābhakaras tadā svajanabandhuvirodhakaraś ca sạ \| śaśivimardakaras tu tritīyago dhanayutaṃ nararājasamaṃ naram | prakurute paśuvāhanasaṃyutam sahajapịdanam āśu karoty asau \|

manitthah |

rājamānaṃ tathārogyaṃ dhanalābham ripukșayam | sarvopakramasiddhiś ca trtīye 'bde dinādhipe \| sukhaṃ lābham jayam pumsā̄m dhanāgamam anukramāt | dharme buddhir bhavet pumsām ț trtīyasthe himadyutau || nrpamānam dhanaprāptī ripunāso nirāmayam | gehe mahotsavam nityam trtīye bhüminandane \| lābhāläbham sukham duḥhaṃ śatrumitraiś ca samgamam | varșakāle yadā cāndrị̣ sahaje kurute nṛ̣ām \| trtīye 'lpasukhaṃ lābham suhrdbandhusamāgamam | nṛnāṃ strīpakșatạ̣ saukhyam sevāyāś ca sukhaṃ gurau \| tritīye 'lpasukham pumsām dhanavyaya upadravah | vivādah svajanaih sārdham varșe daityapurohite \|

4 sasyā] sakhyā G; śasyā K T 13 dinādhipe] dhanādhipe B 14 jayaṃ] bhayaṃ B N K T M 15 bhavet] bhave BN 16 dhanaprāptī] dhanāpti N 19 sahaje] sahame K T M 22 vyaya] om. G

1-2 śaśi ... dhanāgamam] TPK 4.3 $\quad 3-4$ tṛtīya ... varșe] TPK 5.3 $\quad 5^{-6}$ bhṛgus ... varșe] TPK 6.3 7-8 ravi ... sah] TPK 7.3 9-10 śaśi ... asau] TPK 8.3 
If Mercury occupies the third house, then it removes all sorrows; there is increase of honour and renown; it makes pleasures of the body and acquisition of wealth.

Occupying the third, Jupiter makes triumh on account of the king and increase of renown, and great increase of grains, clothes and wealth, in [that] year.

[Occupying] the third, Venus will bring about happiness in various ways: it makes acquisition of wealth, increase in beauty and assistance from people [in general] in [that] year.

Saturn occupying the third becomes a destroyer of enemies and a giver of wealth: it makes gain of land and wealth then, but makes conflict with one's own people and friends. ${ }^{47}$

Rāhu occupying the third endows a man with wealth and makes him equal to a prince of men; it brings him cattle and vehicles [but] quickly makes siblings suffer.

[And] Manittha [says]:

There is honour from the king, good health likewise, gain of wealth, destruction of enemies and success in all endeavours if the sun is in the third [house] in the year.

Men will have happiness, gain, victory over men, acquisition of wealth and inclination towards piety, in [that] order, if the moon occupies the third.

There is honour from the king, gain of wealth, destruction of enemies, good health, and continuous celebrations at home if Mars is in the third.

If Mercury is in the third house at the time of [the revolution of] the year, it makes gain and loss for men, happiness and sorrow, and encounters with enemies and friends.

If Jupiter is in the third, there is little happiness [but] gain, the company of friends and kinsmen, happiness from women for men, and happiness from service.

If Venus is in the third in the year, there is little happiness for men, loss of wealth, misfortune and quarrels with one's own people.

47 Giving bandhu the extended meaning of 'friend' to distinguish it from the otherwise synonymous svajana. 
sarvaduḥkhādimokșaś ca rājamānam dhanāgamam |

varșakāle yadā sauris tritīye kurute nṛnām \|

rājamānaṃ tathaiśvaryam ārogyạ̣ vibhavāgamam |

śatrukșayaḥ suhṛtsaukhyam rāhau varșe tṛtīyage \|

iti sahajabhāvavicārah ||

atha caturthabhāvavicāraḥ | tatra caturthabhāve kiṃ cintanīyam ity uktạ̣ caṇ̣eśvareṇa |

gṛhaṃ nidhānam vivarapraveśo lataușadhikșetrakhalādi vāpī|

mitraṃ dhrtastrīparapumprayogo gamāgamau yānasukhādikaṃ ca \|

sthānacyutir lābhagrhapraveśau buddhir janitrījanakaś ca tadvat |

deśādikāryāny api lābham asya vicintyam etat tu caturthabhāve \|

atrāpi vicāraḥ pūrvavaj jñeyaḥ | yādavaḥ |

arke ca candre sakhale caturthe pituś ca mātuh kramaśậ prapịdā | sūryoḍupasthānagate 'rkaje 'tra tābhyām virodho hy apamānitā ca \|

janmasthasūryacandrarāśige śanau varṣe |

janmābdayos turyapatī savīryau

naștānnabhasthau tu sasaumyam ambu|

1 sarva] sarve B N 4 kṣayah] kṣayam K T M $\quad 6$ uktam] uktaś K T 8 nidhānaṃ] vidhānaṃ N K T M || latauṣadhi] latauṣadha G || vāpī] vāpi B N 9 dhṛta] dhṛtaṃ B N G \| strīpara] strīpața $G \quad 12$ yādavaḥ] om. B N 13 sakhale] sabale B N 14 sūryoḍupa] sūrye duștạ M \| apamānitā] apamānatā K T M 15 janmastha] janmasthe T M

13-14 arke ... ca] TYS $12.42 \quad$ 16-612.2 janmā- ... kāvyayoḥ] TYS 12.44 
When Saturn is in the third at the time of [the revolution of] the year, there is release from all unhappiness and so on; it makes honour from the king and gain of wealth for men.

There is honour from the king, dominion likewise, good health, acquisition of fortune, destruction of enemies and happiness from friends if Rāhu occupies the third [house] in the year.

This concludes the judgement of the third house.

\subsection{The Fourth House}

Next, the judgement of the fourth house. Concerning that, Candeśvara describes what is to be considered from the fourth house:

Home, treasure, entering a crevice, creepers, plants, fields, granaries and so on, pools, friends, one's mistress taking another man [as her lover], coming and going, happiness from vehicles and so on, losing one's place, gain and entering a [new] house, intelligence, mother and likewise father, working with the land and gain from that: this is to be considered from the fourth house.

Here, too, [the method of] judgement should be understood as before. [And] Yādava [says in Tājikayogasudhānidhi 12.42]:

If the sun or the moon is with a malefic in the fourth, there is suffering to the father or mother, respectively. If Saturn here ${ }^{48}$ occupies the place of the sun [or] the moon, there is quarrel with them or disrespect.

[This means] if Saturn in the year occupies the sign occupied by the sun [or] the moon in the nativity. [Continuing from Täjikayogasudhānidhi 12.44]:

[If] the rulers of the fourth [house] in the nativity and in the year are strong, not occupying a sign where they are corrupted, and the fourth house is with a benefic, there will be happiness for them, unhappiness

48 'Here' can be understood as 'in this house' (the fourth) or 'in this year'. Balabhadra seems to favour the latter interpretation. 
sukham tayoh syād asukham vilomād

arkendubhe tatsukham ijyakāryayoh \|

bhe sthāne |

sūtau bhaved yo hibuke 'bdake ca tasmiṃs tu mandārayute viśeșāt | pitror vyathā syād atha vāhagehakșetrādikānām idam evam ühyam \|

yaḥ rāsih | tejaḥsiṃhena janmacaturthabhāvādhīśasthāne śanibhaumayute pitror aśubham ity uktam |

pitro rujo 'bdajanușoś ca sukheśadagdhe

śanyārayoh savasukheśapade 'pi caivam || iti

tājikabhūṣanẹ |

kuryād vilupto vijito 'ribhītị̣ pituḥ sukheśah sahameśvaro vā\|

jīrṇatājike |

sukhasaminthe sukhādhisse vā lagneśetthaśālake| pitroh sukhaṃ mūsarīphe tayor duḥkham prajāyate \| sukhạ̣ paśyati turyeśas turye ca sahameśvarau |

mātāpitroh sukham tatra varșe bhavati niścayāt ||

mātāpitroś ca sahame krūrite muthahā tayoḥ|

daśamasthā tadā duḥkham pitroḥ syād yavanā vidụ̣ \|

1 asukhaṃ] asum $\mathrm{N} \quad 2$ arkendubhe tat] arkendum etat $\mathrm{K}$ T M 4 sūtau] sūto B N \| hibuke] hinuko G; hituke K T 5 vyathā] vāpyā K T; vīrya M \| atha vāha] athavābda G; apavāda K M; athavāda T \| geha] gehe G \| ādikānām] ādhikānāṃ B N || evam] om. B N || ūhyam] ūhya B N 6 yaḥ] om. B N K T \| rāśiḥ] om. K T \| bhāvādhīśa] bhāvādhīśạ B N || sthāne] sthani K T \|| yute] yute add. G 9 sava] sa ca B N; śava G; sa na K M 11 vijito] viyuto G || sukheśah] sukheśo B N G 13 lagneśettha-] lagnettha- $G \quad 15$ turyeśas] scripsi; turyeśo B N G K T M || ca] om. G 17 mātā] mātrā B 18 yavanā] yāvanā B N T

4-5 sūtau ... ūhyam] TYS $12.45 \quad 8-9$ pitro ... caivam] DA $20.2 \quad 11$ kuryād ... vā] TBh 4.42

2 tatsukham ijyakāvyayoh] This phrase appears from the evidence of MS TYS 1 to have been transposed from 12.43 by a saut du même au même. $\quad 4-5$ sūtau ... ūhyam] This stanza is misnumbered as 44 in MS TYS (following the actual verse 44 ). 
if the reverse. If Jupiter and Venus are in the sign of the sun [or] moon [in the nativity], there is happiness for them. ${ }^{49}$

'In the sign' [means] in the place. [Continuing from Täjikayogasudhānidhi 12.45]:

In particular, if that which was in the fourth house in the nativity is joined by Saturn and Mars in the year, there will be anguish for the parents, and the same should be judged concerning vehicles, home, fields and so on.

'That which' [means] the sign. Tejahsiṃha says [in Daivajñälaṃkrti 20.2] that if the place of the ruler of the fourth house in the nativity is joined by Saturn and Mars, there is misfortune for the parents:

There is illness for the parents if the ruler of the fourth house of the year and of the nativity is burnt, and likewise if Saturn and Mars are in the place of the ruler of the fourth house in the nativity.

[And] in Tājikabhūṣaṇa [4.42 it is said]:

The ruler of the fourth house or of the sahama [of the father] being deprived [of light] or vanquished will make danger from enemies for the father.

[And] in the Jirnatājika [it is said]:

If the ruler of the fourth house occupies the fourth house or has an itthaśa la with the ruler of the ascendant, there is happiness for the parents; if there is a müsarihpha between them, unhappiness results. [If] the ruler of the fourth aspects the fourth house, and the rulers of the sahamas [of the father and mother] are in the fourth, there is certain happiness for the mother and father in that year. But if the sahama of the mother [or] father is afflicted, [and if] the munthahā occupies the tenth [sign] from those two, ${ }^{50}$ then Yavanas understand that there will be suffering to the parents. If the ruler of that sign [which was] the

49 That is, for the parents.

$5^{\circ}$ That is, from the sahama in question. 
janmakāle 'mbubhavanam tadīse vābdaveśane | dagdhe kleśo bhavet pitror vā tatsthāne 'rkabhümijau ||

vāmanah |

mātāpitroḥ sadmanāthe naște nāśas tayor bhavet | udite viryayukte ca tayoh saukhyam prajāyate \|

varșatantre |

mātuh pituś ca sahame tanupetthaśäle turye 'pi cettham avagaccha sukhāni pitroḥ| ced așțamādhipatinā krtam itthaśālam pitror vipad bhayam aniștakhagesarāphe \|

granthāntare |

lagnādhipenendunā vā muthaślam sukheśvarah | kurute saumyayugdrșțo grhabhūmyādiläbhadah $\|$ lagne sukheśvaraś candralagneśau turyasaṃsthitau | saumyayuktekșitau varșe gṛhabhümyādilābhadau || lagne lagneśaturyeśau turye vā lagnaturyapau | candrānvitau vā saumyāạhyau gṛhabhūmyādiläbhadau \|

samarasiṃhạ̣ |

jāte ca naktayoge lagnapaturyeśayoś ca parahastāt | sidhyati prcchakakāryam viparītam vyatyayājjñeyam \|

1 kāle 'mbu] kāleṃdu G T $\|$ tadiśe] tadīśośe K; tadīśo M 8 turye] turyo B N \| cettham] vettham K T M || sukhāni] sukhāva N 8-616.2 pitroh ... jīva] om. N 9 itthaśālaṃ] ne add. B 11 granthāntare] om. B N G $12-20$ lagnādhi ... jñeyam] om. B N 12 vā] ca K T M 14 candralagneśau] candras tadrāśau K T M $18-20$ samarasiṃhah ... jñeyam] om. K T M

7-10 mātuh ... khagesarāphe] VT 8.5 
fourth house at the time of the nativity is burnt in the revolution of the year, there will be suffering to the parents, or [if] Saturn and Mars are in that place. ${ }^{51}$

[And] Vāmana says:

If the ruler of the lot of the mother [or] father is corrupt, they will die; but if it is [heliacally] risen and endowed with strength, happiness results for them.

[And] in Varșatantra [8.5 it is said]:

If the sahama of the mother or father has an itthaśäla with the ruler of the ascendant, or the fourth similarly [has such an itthaśäla], understand there to be pleasures for the parents. If an itthaśāla is made with the ruler of the eighth [house], there is misfortune to the parents; if an isarāpha with a malefic planet, danger. ${ }^{52}$

[And] in another book [it is said]:

[If] the ruler of the fourth house, joined to or aspected by benefics, makes a mutthaśila with the ruler of the ascendant or with the moon, it gives gain of houses, land and so on. [If] the ruler of the fourth house is in the ascendant [and] the moon and the ruler of the ascendant occupy the fourth, joined to or aspected by benefics, they give gain of houses, land and so on in [that] year. [If] the ruler of the ascendant and the ruler of the fourth house are in the ascendant, or the rulers of the ascendant and the fourth are in the fourth, accompanied by the moon or joined to benefics, they give gain of houses, land and so on.

[And] Samarasiṃha says [in the Tãjikaśāstra]:

If a nakta configuration is produced between the ruler of the ascendant and the ruler of the fourth, the business of the querent is accomplished by another's hand; from the reverse [situation], the opposite is to be understood.

$5^{1} \quad$ Or, possibly but less likely, 'the sun and Mars'.

$5^{2}$ It is not clear how the author envisions these configurations to arise, as they normally apply only to aspects between planets and depend on their respective velocities. 
hāyanasindhau |

jōvendū kendragau syātāṃ sukhe vā jīvabhārgavau | nidhānasya bhavel läbhah krte yatne 'tra vatsare \| candrārkaguruśukrānāam ekah svāṃśe sukhe 'thavā| svakīyam parakīyam vā nidhị̣ dadyād balì grahạ || turyalagneśvarau yuktau drșțau saumyagraheṇa vā | tatra mitreṇa samyyogo varșe bhavati niścayāt || lābheśasya phalaṃ jñeyam pūrvavan mitrasaṃgame | lagnam svasvāminā drștam tanmitrenāatha saṃyutam | caturtham ca tadā varșe deśasampattim ādiśet \| suhrdīsena samyuktād vīkșitād vā caturthabhāt | gurujñaśukrair yuktād vā vīkșitāe chaśināpi vā | sukham vāhanavrddhim ca varșe tatra vinirdiśet $\|$ läbhe vā nidhane vāpi yadi pāpo vyavasthitah | caturthe ca sapāpe ca tadā duḥkhägamam vadet \|

hillājah |

sukhādhiśasya daśame tasmāt saptamakarmabhe | śubhe lābhāya saukhyasya vināśāyāśubhānvite \| sukhabhāve śubhair drsțte śubhagrahayute 'thavā | dhrtabhāryālābhayogah śukradrștau viśeșatah \| caturthe krürakhețas tu śubhadrșțivivarjitah | dhrtabhāryāmaraṇado varșe proktah purātanaih $\|$

atha caturthabhāvasthitānāṃ sūryādīnāṃ phalāni padmakośe |

paśoh pịdanam turyasaṃsthe ravau syāt

krșeh karmaṇo hānir atyantam uktā |

nrpād bhïtikaștam bhaven mātrpị̣̂o-

dare hrdy api syāt prapị̄ābdamadhye \|

2 jīvendū] jīvendu B N $\quad 3$ 'tra] ca K T M 4 'thavā] śravāḥ M $\quad 5$ svakīyaṃ] scripsi; svakīyāṃ B N G K T M || parakīyaṃ] scripsi; parakīyāṃ B N G K T M 8 lābheśasya] lābhesaspha B N 9 sva] om. B N || svāminā] svāmi N || mitreṇātha] mitre nātha B N 11 suhṛdīśena] suhṛdāṃśena K T; suhṛdaṃśena M $\quad 15$ caturthe] caturthaṃ B N 17 daśame] scripsi; daśamaṃ B N G K T M 18 lābhāya saukhyasya] śubhāya mukhyasya G || vināśāyā] vināśāya N $\quad 20$ śukra] śubha B N $\quad 21$ śubha] śukra G $\quad 26-27$ pīḍodare] pīḍohare K $\quad 27$ api] ari $\mathrm{N}$ a.c.; adi $\mathrm{N}$ p.c.

24-27 paśoh ... madhye] TPK 1.4 
[And] in the Hāyanasindhu [it is said]:

Should Jupiter and the moon occupy angles, or Jupiter and Venus be in the fourth house, there will be gain of a treasure if an effort is made in this year. Or else, [if] one among the moon, the sun, Jupiter and Venus is in its own division in the fourth house, [that] strong planet will give [the native] a treasure, whether [it be] his own or another's.

[If] the rulers of the fourth and the ascendant are joined to or aspected by a benefic planet, union with a friend is certain in that year. For encounters with friends, the results of the ruler of the eleventh house should be understood in the same way. [If] the ascendant is aspected by its own ruler and the fourth is joined by a friend of that [ruler], one should predict prosperity from the land in that year.

From the sign of the fourth [house] being joined or aspected by the ruler of the fourth house, or joined or aspected by Jupiter, Mercury and Venus, or by the moon, one should predict happiness and increase in vehicles in that year. [But] if a malefic occupies the eleventh or eighth house, and the fourth is joined by a malefic, then one should predict the arrival of suffering.

[And] Hillāja [says]:

If a benefic is in the tenth [sign] from the ruler of the fourth house [or] in the seventh or tenth from that [sign], it makes for increase of happiness; for destruction, if [the sign in question is] joined by a malefic. If the fourth house is aspected by benefics or joined by benefic planets, it is a configuration for acquiring a mistress, particularly if Venus aspects. But a malefic planet in the fourth, devoid of the aspects of benefics, is said by the ancients to bring death to one's mistress in [that] year.

Next, the results of the sun and other [planets] occupying the fourth house [are described] in [Tājika] padmakośa [1.4, 2.4, 3.4, 4.4, 5.4, 6.4, 7.4, 8.4]:

If the sun occupies the fourth, there will be suffering to cattle, and exceedingly [great] loss is declared from agriculture; there will be the evil of danger from the king, suffering to the mother, and ailments of the stomach and heart in [that] year. 
śaśānike caturthe ca bhūpājjayah syāt krșeh karmaṇo lābhavān syāt sukhī ca | dhanāptim kraye vikraye vābdamadhye sukham vāhanānāṃ ripor nāśanam ca \| caturthe kuje vahnipịdām tathārtim

paśoh pịdanam vyagratāọ kleśakaștam |

krșeh karmaṇo hānim apy eva kuryāt kraye vikraye cābdamadhye tathaiva $\|$ budhaś caturthah prakaroti saukhyam dravyāgamam mitrasamāgamam ca| gobhūhiranyādi labheta saukhyam mahat sukham vāhanam atra varșe \| surejye sukhasthe sukham vāhanānām kraye vikraye lābhakārījanasya | bhaved bhūpapakșāj jayo hāyane 'smin mahālābhadạ̣ syāt krșeh karmanaś ca \| prathamadaityagurụ̣ sukhago yadā sukhakarah krșivāhanayos tadā| dharaṇivājisuvarnasamāgamo bhavati bhūpasamo manujas tadā || bandhusthānagato divākarasutah syād dhāyane kașțado bhïtịn hānim upakrame ca kurute netrodare pị̣̂an | bandhūnām atha pị̣anam prakurute lokāpavādam vyathām agneś cāpi bhayaṃ paśoś ca maranạn hāniṃ krșin̄ạm tathā || himāṃśo ripus turyago vāhanānāṃ vināśạ̣ tathā bhūpapakșād bhayam ca| kaphārtim ca kaștạn tathā vāyupị̄̂ạm videśe bhramam hāyane 'smin karoti $\|$

\footnotetext{
1 jayaḥ syāt] jayaś ca $\mathrm{G} \quad 11$ labheta] labhe tatra B N 12 vāhanam] hāyanam $\mathrm{G} \quad 16$ karmaṇaś] karmaṇe K T; karmaṇā M 17 daitya] deva B G \| sukhago] sukhado G || yadā] ya G 21 vyathām] vyayaṃ tv B N; vṛthām K; vṛthā M 22 agneś] vahneś M || hāniṃ] hānih B N; hāniṣ K T

1-4 śaśánke ... ca] TPK 2.4 5-8 caturthe ... tathaiva] TPK 3.4 $\quad 9^{-12}$ budhaś ... varṣe] TPK 4.4 13-16 surejye ... ca] TPK 5.4 17-18 prathama ... tadā] TPK $6.4 \quad 19-22$ bandhu ... tathā] TPK $7.4 \quad 23-26$ himāṃśo ... karoti] TPK 8.4

$4 \mathrm{ca}$ ] At this point $\mathrm{B} \mathrm{N}$ add a metrically somewhat defective stanza in the same style and metre as the surrounding verses, apparently an alternative to the one immediately following but not present in independent witnesses of the TPK: kujas turyago vahnibhītim prakuryād gṛhe vāhane mātrpakșe ca pị̄̂am | bhaved dușțavairam rudhirodbhavārtiṃ daśā neștakārī tathā kaștadam syāt $\| \quad 17$ daityaguruh] $\mathrm{N}$ repeats daityaguruh in the margin.
} 
But if the moon occupies the fourth, there will be triumph on account of the king; [the native] will profit from agriculture and be happy. [It makes] gain of wealth from buying and selling in [that] year, happiness from vehicles and the destruction of enemies.

If Mars is in the fourth, it will make damage by fire, injury likewise, suffering to cattle, agitation, the evil of affliction and loss from agriculture, and likewise from buying and selling, in [that] year.

Mercury [in] the fourth brings about happiness, acquisition of goods and the company of friends; [the native] will gain cows, land, gold and so on, happiness, great joy, and vehicles in this year.

If Jupiter occupies the fourth house, there is happiness from vehicles; it makes a man gain from buying and selling; there will be triumph on account of the king in this year, and it gives great gain from agriculture.

When Venus occupies the fourth house, it makes happiness from farming and vehicles; there is acquisition of land, horses and gold; then a man becomes equal to a king.

Occupying the fourth house, Saturn will give evils in [that] year: it makes danger, loss in undertakings and suffering of the eyes and stomach; it further brings about suffering to kinsmen, the censure of the world, anguish and danger from fire, the death of cattle, and likewise loss from farming.

Rāhu occupying the fourth house destroys vehicles and likewise makes danger on account of the king, illness from phlegm, evil, and likewise suffering from [the humour of] wind, and roaming abroad in this year. 
manitthah |

ișțasvajanavidveșaṃ bhayaṃ bhūpālasambhavam | catuṣpadamanușyānām bhayam sūrye caturthage \| suhrdbandhukalatrādisaukhyam caiva dhanāgamam | gomahişyādiläbham ca caturthe yadi candramāḥ \| deśātanam ca kaștam ca hrdi duḥkham suhṛtkṣayam | kuțumbakalaham caiva caturthe bhüminandane \| mitrastrïbandhujam saukhyam caturañghridhanāgamam | varșe caturthagaś cāndrị̣ kurute niyatam nṛ̣ām || jāyāputrasuhrtsaukhyaṃ nrpamānam dhanāgamam | bhümivāhanavidyāptiś caturthe hāyane gurau || nrpamānam athaiśvaryam ārogyaṃ vibhavāgamam | mitrasvajanajam saukhyam hāyane hibuke bhrgau \| mātrpakșe bhavet kașțam pravāsaṃ ca dhanakșayam | asaṃtoșo rājapịdā caturthe ravinandane $\|$

cintā duḥkhaṃ pravāsaś ca vivādaḥ svajanaiḥ saha | catuṣpadāḥ kșayam yānti rāhus turyagato yadi $\|$

iti caturthabhāvavicāraḥ ||

atha pañcamabhāvavicārah | tatra pañcamabhāve kiṃ vicāranīyam ity uktaṃ caṇdeśvareṇa |

2 ișțasva] iṣtas tu KTM 6 ca kașțaṃ ca] sakașțaṃ ca G; ca saṃkașțaṃ KT M || hṛdi] suhṛ̂ KTM 12 mānam] yānam BN 14 pravāsaṃ] gravāsaṃ N \| dhanakṣayam] dhanāgamạ̣ B N 16 vivādaḥ] pravādas K T M 17 catuṣpadāḥ] catuṣpadāṃ B N; catuṣpadā G \|| yadi] ta add. N 18 bhāvavicāraḥ] bhāvaḥ G K T M 
[And] Manittha [says]:

There is enmity with loved ones and one's own people, danger arising from the king, and danger from quadrupeds and men, if the sun occupies the fourth.

There is happiness from friends, kinsmen, wife and so on, acquisition of wealth, and gain of cows, buffaloes and so on, if the moon is in the fourth.

There is roaming through the land and evils, suffering of the heart and loss of friends, and quarrels in the household, if Mars is in the fourth.

Occupying the fourth in the year, Mercury surely makes happiness from friends, women and kinsmen and acquisition of quadrupeds and wealth for men.

There is happiness from wife, children and friends, honour from the king, acquisition of wealth and gain of land, vehicles and learning, if Jupiter is in the fourth in the year.

There is honour from the king and rulership, good health, acquisition of fortune, and happiness from friends and one's own people, if Venus is in the fourth house in th year.

There is evil on the mother's side, living abroad and loss of wealth, discontent and suffering from the king, if Saturn is in the fourth.

There is anxiety, suffering, living abroad and disputes with one's own people, and quadrupeds are destroyed when Rāhu occupies the fourth.

This concludes the judgement of the fourth house.

\subsection{The Fifth House}

Next, the judgement of the fifth house. Concerning that, Canḍeśvara describes what is to be judged from the fifth house: 
nānāprayogo vinayaprabandhà vineyavidyānayabuddhimantrāh | saṃdhānagarbhāñgabhavādi kiṃcit prajñā sutākhyaṃ sutasaṃjñabhāve ||

atrāpi vicāraḥ pūrvavat | samarasiṃhah |

varșapatau sati jīve putre cāye ca putratah saukhyam |

krūrārdite ca duḥkham bhaume 'py evam phalam tādṛk\|

ravibudhayor apy evam sthitayoḥ śubhasamyute phalaṃ pūrṇam |

varșapatau sutasahame śubhadrște 'patyasaṃtoșah $\|$

śukre sutasaptapatau varșe tatsthānage ca tanupatinā $\mid$

krtamuthaśile ca tanayayuvatiprāptị svabalapramānenena \|

atra janmani pañcamasaptamabhāvādhīśe śukre varșe pañcamasaptamasthe lagneśena kṛtetthaśāle krameṇa putrastrīprāptị̣ syād ity arthạ̣| tejạ̣siṃhạ |

j̄̄vāspade januși tatra gate 'tra cābde saukhyam sutād asukham ittham inātmaje tu| evam budhe sutasukham na ca tat sabhaume caivam sute śanipade vibale tadīse $\|$

atra viśeșam āha samarasiṃhaḥ| mandasthānagaputre tannāthe jñe 'dhikāriṇi tu putrāptiḥ ||

1 vinaya] vinayā $\mathrm{K} \quad 2$ garbhānga] garmānga $\mathrm{G} \quad 4$ cāye] cāpe K T M $\quad 6$ budhayor apy] budhayopy B N 8 sapta] saptama G 9 tanaya] tanayam K T M 10 saptama $^{2}$ ] om. K T M 11 putra] putrah N 15 ca] va B N 16 vibale] py abale G K T M 18 tannāthe] tabhāthe N $\|$ tu] om. B N

13-16 jīvāspade ... tadīśe] DA 21.2 
Different practices, compositions on conduct, bringing knowledge to pupils, understanding, incantations, [sexual] union, the forming of the limbs of a foetus and other such [meanings], wisdom and children are said [to be judged] from the fifth house. ${ }^{53}$

Here, too, judgement is [to be made] as before. [And] Samarasiṃha [says in the Tãjikaśāstra]:

If Jupiter as ruler of the year is in the fifth or eleventh house, there is happiness from children. If it is afflicted by malefics, there is unhappiness, and if Mars is such, the result is similar. ${ }^{54}$ Of the sun and Mercury placed thus, if [the one ruling the year] is joined to benefics, the [good] result is full. If the ruler of the year is on the sahama of children, aspected by benefics, there is satisfaction with children. If Venus rules the fifth or seventh house and occupies it in the year, forming a mutthaśila with the ruler of the ascendant, [the native] obtains children or a woman, in accordance with its strength.

This means that if Venus, ruling the fifth or seventh house in the nativity, occupies the fifth or seventh in the year, forming an itthaśäla with the ruler of the ascendant, [the native] obtains children or a woman, respectively. [And] Tejaḥsiṃha [says in Daivajñālaṃkṛti 21.2]:

If [the fifth house] is the place of Jupiter in the nativity and [Jupiter] is there in this year too, there is happiness from children; unhappiness, if Saurn is so [placed]. If Mercury is such, there is happiness from children, but not if it is joined by Mars, nor if the fifth house is the place of Saturn [in the nativity] and its ruler is weak.

Concerning this, Samarasiṃha states a special rule [in the Tãjikaśāstra]:

But if the fifth house is the place of Saturn and its ruler Mercury has authority [in the year, the native] gets children.

[Continuing from Daivajñālaṃkrti 21.3:]

53 Although text witnesses largely agree, the grammar of this verse is eccentric, and several meanings are uncertain.

54 That is, if Mars as ruler of the year occupies the fifth or eleventh house. 
bhaumendujau śubhagṛhe śubhavikssitau cel

lābhe sute 'pi ca tadà sadapatyasaukhyam |

puträdhipe bhrgusute tu kalatrage 'nga-

nāthetthaśālakrti putrakalatrasaukhyam ||

tājikasāre |

devārcito janmani yatra rāśau varșe sa rāśir yadi pañcamasthaḥ| tatra sthite varșapatau budhe vā bhaume 'pi vā putrasamudbhavah syāt $\|$ yadrāśigo janmani sūryasūnur varșe ca tadrāśigatam vilagnam | saṃtānakașțạ̣ ca kujaḥ sutastho vilomagaḥ putraharo niruktaḥ \| sutagatah sutapaḥ sabalo yadā sutasukhaṃ bahulam tanute tadā $\|$

yādavaḥ |

sute savirrye śubhayuninirīkșite suteśvare kendragate balānvite | tathaiva sāde sutasaukhyam ìritam sutātyaya h syād viparïtage tathā $\|$ budhakșamājau ca śubhāspadāyadhi-

gatau bhavetām śubhadrgyutau sukham |

januhsuteśe 'bdakalatrage bhrgau

tanūpamukhyākhyayutau sukham bhavet $\|$

sūtau putrapatau samātanugate 'ngeśetthaśāle balodrikte putrasukham januhsutapatau sādeśvare 'bde 'thavā| vyaste vā sutage śubhe śubham atho krūrārdite nirbale sūtau sūnupatau ca duḥkham atulam sāde 'pi sādeśvare \|

3 kalatrage 'ñga] scripsi; kalatragāṃga B N G; kulatragāṃga K T; kulatrapāṃga M 6 devārcito] devārcite B N K T M \| varșe sa] varșeśa M 8 sūrya] bhānu K T M \| gataṃ] gamaṃ G 9 kujah] kuje B N \| sutastho] sutasthe B N; sutasthau K T \| niruktah] niyuktah G 10 sutapah sabalo] sutapastyabalo N \| tanute] kurute K T M 13 sāde] scripsi; sādhye B N; śāde G a.c.; hāde G p.c.; sāvde K T; sābde M || sutātyayaḥ] sutālpayas K T 14 kṣamājau] kșmājau B N 18 patau] gatau K T M \| gate 'ngeśetthaśāle] gateṃśatthaśāle B; gateṃśetthaśāle $\mathrm{N} 19$ rikte] putre add. $\mathrm{G} \|$ suta] sute B N \| sādeśvare] sādeśvaro B; sāvdeśvare $\mathrm{K}$ T; sābde khare M 20 śubhe] śubhai B 21 duḥhham] dușțam B N \| sāde] sābde M \| sādeśvare] sāvdeśvare K T; sābdeśvare M

1-4 bhaumendujau ... saukhyam] DA 21.3 6-9 devārcito ... niruktaḥ] TS 203-204 10 suta ... tadā] TS $178 \quad 12-13$ sute ... tathā] TYS 12.47 14-21 budha ... sādeśvare] TYS 12.4950

3 kalatrage 'nga] The emendation is supported by MSs DA1, DA3. 
If Mars and Mercury are in the domicile of a benefic, aspected by benefics, in the eleventh or fifth house, then there is happiness from good children. And if Venus as ruler of the fifth house occupies the seventh house, forming an itthaśa la with the ruler of the ascendant, there is happiness from wife and children.

[And] in Tājikasāra [203-204, 178 it is said]:

If the sign where Jupiter was in the nativity occupies the fifth [house] in the year, and Mercury or Mars occupies it as ruler of the year, the birth of a child will take place. And if the sign where Saturn was in the nativity occupies the ascendant in the year, there is evil to one's progeny. Mars retrograde, occupying the fifth house, is declared a destroyer of children.

When the ruler of the fifth house occupies the fifth house in strength, then it bestows abundant happiness from children.

And Yādava says [in Tājikayogasudhānidhi 12.47, 49-5o]:

If the fifth house is strong, joined or aspected by benefics; if the ruler of the fifth house, endowed with strength, occupies an angle; and if the lot likewise [is strong and benefic], happiness from children is declared [as the result]. Likewise, if [all are] conversely situated, the death of a child will occur.

Should Mercury and Mars occupy the ninth, tenth, eleventh or fifth house, joined to the aspects of benefics, there is happiness. If Venus, ruling the fifth house of the nativity, occupies the seventh house in the year, in the configuration called the foremost with the ruler of the ascendant, there will be happiness. ${ }^{55}$ If the ruler of the fifth house of the nativity, full of strength, occupies the ascendant of the year, in an itthaśāla with the ruler of the ascendant, there is happiness from children, or else if the ruler of the fifth house of the nativity is ruler of the lot [of children] in the year. Or if a separate benefic occupies the fifth house, there is good [fortune relating to children]; but if the ruler of the fifth house in the nativity is weak and afflicted by malefics, there is unequalled suffering, or if the ruler of the lot [of children or] the lot [itself is so afflicted]. 
vāmanah |

punyasadmani putrasthe putrāptih śubhavīkșite |

lagnaputreśvarau putre śukraś candro 'thavā guruh \|

putradah putrabhavanam yaduccam sa graho yadi |

svoccam prayāti tvaritam putrāptis tu tadā bhavet \|

putrasadmeśvare naște putranāśam samādiśet |

tasminn abhyudite putrasthite putrāptim ādiśet ||

varșatantre |

yatrejyo januși grhe vilagnam etat

putrāptyai budhasitayor apittham ūhyam |

yadrāśau januși śanị kujaś ca so 'bde

putrārtim tanusutagaḥ karoti nūnam \|

yadrāśigo grahah sūtau sa rāśis tatpadābhidhaḥ|

balījanmotthasaukhyāya varșe tadduḥkhado 'nyathā $\|$

cet padābhidho rāśir varșe balī tadā janmakālīnatadbhāvotthaśubhaphalajanako bhavati | nirbalaś cet tadā tadbhāvotthāśubhaphalajanako bhavatīti jñeyam | hillājah |

yadi lagneśaputreśau mitroccopacayarkșagau|

gurujñavīkșitau yuktau putrasaukhyakarau matau \|

lagnāt kendratrikoṇasthau vișamāṃśagatāo ubhau|

putrajanmapradāv etau samāmnsé strījanipradau ||

nìcāstārigatāo etau yadi vakragrahānvitau |

tad yogaghātakāv etau samarkșe vișame 'pi vā $\|$

atra saṃtānayogakartāro grahāḥ viṣamarkṣe viṣamanavāṃśe vā sthitāḥ puṃjanmakarāḥ | samabhe samanavāṃśe ca kanyājanmakarāḥ syur iti viśeșah | jīrṇatājike |

2 putrasthe] putrepsthe $\mathrm{G} \quad 3$ lagna] lagne B a.c. $\mathrm{N} \quad 4$ sa graho] sadgraho K T M $\quad 9$ yatrejyo] yatrejye $\mathrm{G} \|$ gṛhe] grahe G 10 putrāptyai] putrātthai N $\|$ ūhyam] ūhye B N $\quad 12$ putrārtiṃ] putrāptiṃ G 13 tatpadābhidhaḥ] tatpabhidhạ̣ N 14 janmottha] janmokta K T M 15 padābhidho] padābhidhau M \| varșe] varșo N \| tadā] tadā add. G 16 tadā] om. G || tad] om. B N 18 lagneśa] lagnepa G \| mitroccopacayarkṣagau] mitroccapacayakșagau $\mathrm{G} \quad 25$ puṃjanma] putrajanma $\mathrm{T}$

9-12 yatrejyo ... nūnam] VT 9.5 13-14 yad ... 'nyathā] VT 9.8 
[And] Vāmana says:

If the lot of fortune occupies the fifth house aspected by benefics, [the native] has a child. The rulers of the ascendant and the fifth house in the fifth house, or else Venus, the moon, or Jupiter, give children. If the planet whose exaltation the fifth house is enters its exaltation, then [the native] will soon get children. If the ruler of the lot of children is corrupt, one should predict the death of children; [but] if it is [heliacally] risen, occupying the fifth house, one should predict having children.

[And] in Varșatantra [9.5, 8, it is said]:

The ascendant being the domicile where Jupiter was in the nativity makes for having children [in that year]; the same is to be judged for Mercury and Venus. [But] the sign where Saturn and Mars were in the nativity occupying the ascendant or fifth house in the year certainly makes suffering for children.

The sign that a planet occupied in the nativity is called its place. Strong in the year, it makes for happiness produced [by the house occupied] in the nativity; otherwise, it gives suffering from that [house].

It is to be understood that if the sign called the place [of a planet] is strong in the year, then it produces good results arising from the house [falling] there at the time of the nativity; if weak, then it produces evil results arising from that house. [And] Hillāja [says]:

If the ruler of the ascendant and the ruler of the fifth house occupy the sign of a friend, their exaltation or a place of increase, aspected by or joined to Jupiter and Mercury, they are said to make happiness from children. Both these [planets] occupying angles or trines from the ascendant and uneven divisions bring about the birth of sons; in even divisions, they bring about a female birth. If these two [planets] occupy their fall, [heliacal] setting or [the sign of] an enemy, joined to retrograde planets, whether in an even sign or an odd one, then they destroy the configuration [for children].

Here, the planets forming the configuration for progeny occupying an uneven sign or uneven ninth-part cause male births; in an even sign and even ninth-part, they cause the birth of a girl. This is a special rule. [And] in the Jirnatäjika [it is said]: 
lagne putrādhipaḥ putre lagneśo yadi saṃsthitạ̣|

bhāvī putras tadā varșe vaktavya iti niścitam \| śukrendū lābhasutagau paśyato vā yathākramam | putrāl lābham sutam lābhàt saṃtatis tatra vatsare \| garbhe garbhädhipas tunge pumān sarvagrahekșitah |

bhāvī nrpas tadā putrah strīgrahah syāt tadanganā $\mid$

pāpakhețah sthito garbhe garbheśena na vīkșite | tadā garbhacyutir vācyānyathā ced garbhasaṃsthitih $\|$

sutādhiśe lābhagate śubhayukte 'tha vīkșite | vā lagnapāt trikonasthe pañcameśe subhekșite \| tathaiva garbhasahame śubhasvāmiyutekșite | tasmin varșe bhaved garbham ity āha yavaneśvarah $\|$ jīvakșetragate candre śukrakșetragate kuje | svakșetrasthe bhrgusute tadā garbham na samśayah \| lagnādhipah sutasthāne jāyāsthānagato 'pi vā | sutajāyādhipau lagne tadā garbhas tu yoṣitah $\|$ janmalagnāt trikonasthah śanị̣ putreśaguryadi tasmin varșe bhaved garbham devaśälamuner matam \| vidyāgrham candrabudhejyaśukrair yutekșitaṃ vā svanavāṃśakaṃ vāa vā svāminā drștayutam tadābde satsphürtividyārucibuddhibhāvaḥ || vidyāgṛhaṃ krūrakhagena yuktam na svāminā naștaśarīrakeṇa| candrena dṛ̦țam sahitam tadābde phalaṃ puroktam viparītakaṃ syāt ||

3 paśyato vā yathākramam] putrajanmakarau mataḥ B; putrajanmakaro mataḥ N 4 putrāl lābham sutam lābhāt] putrāl lābhaṃ sutāt saukhyạ̣ G; sutāt saukhyạ̣ sutaṃ lābhāt K T M || lābhaṃ] lāmaṃ N 5 sarvagrahekșitaḥ] aṃsahasaṃgame B N p.c.; ạ̣sahagasaṃgame N a.c. $\quad 6$ tadanganā] scripsi; tadāṃganā B N G; tadānganā K T M 7 garbheśena na ] scripsi; garbheśo naiva B N G K T; garbheśenaiva M 10 vā] om. B N \|| śubhekșite] śubhe sthite B N 13 śukra] śukre B N 17 putreśagur yadi] putreśasūryadi K; putre gurur yadi M 2O sphūrti] phūrti B N K T

21 gṛham] At this point G adds three quarters of a stanza: caṃdrabudhejyaśukrairyutekșitam vā svanavāṃśakam vā vā svāminā drștayutam tadābde satputrakaṃ.

$5^{6} \quad$ For the ruler of any house in a horoscope to occupy the same house and its exaltation simultaneously, its domicile and exaltation would need to be identical. This is true only of Mercury, whose gender is typically considered ambiguous. Possibly the author is thinking of the ruler of the fifth house of the nativity occupying the fifth house of the revolution. 
If the ruler of the fifth house occupies the ascendant, [and] the ruler of the ascendant, the fifth house, it should be predicted with certainty that a child will be born in that year. [If] Venus and the moon occupy the eleventh [or] fifth house, or aspect the eleventh house from the fifth [and] the fifth house from the eleventh, respectively, there is progeny in that year.

If the male ruler of the fifth house is in its exaltation in the fifth house, aspected by all [other] planets, then the son [born] will become a king; [if the ruler of the fifth house is] a female planet, [the child born will become] the wife of one. ${ }^{56}$

[If] a malefic planet occupies the fifth house, which is not aspected by the ruler of the fifth house, then a miscarriage should be predicted; if the opposite, [a completed] pregnancy. If the ruler of the fifth house occupies the eleventh house joined to or aspected by benefics, or the ruler of the fifth occupies a trine from the ruler of the ascendant, aspected by benefics, and the sahama of pregnancy ${ }^{57}$ is likewise joined to or aspected by its ruler and benefics, there will be pregnancy in that year: so says the lord of the Yavanas.

If the moon occupies a domicile of Jupiter, Mars occupies a domicile of Venus, and Venus occupies its own domicile, then no doubt there is pregnancy. [If] the ruler of the ascendant is in the fifth house or else occupies the seventh house, [and] the rulers of the fifth and seventh houses are in the ascendant, then [the native's] wife [becomes] pregnant. If Saturn occupies a trine from the ascendant of the nativity, [casting] its rays on the ruler of the fifth house, ${ }^{58}$ there will be pregnancy in that year: [this is] the opinion of the sage Devaśāla.

[If] the fifth house is joined or aspected by the moon, Mercury, Jupiter and Venus, or [its] own ninth-part [is so], ${ }^{59}$ or aspected or joined by its ruler, in that year flashes of insight, relish for learning, and intelligence come to be. [But if] the fifth house is joined by a malefic planet [and] not aspected by or joined to its ruler, the body of which is lost, ${ }^{60}$ [or] the moon, in that year the results stated above will be reversed. 
samarasiṃhạ |

asmin varșe 'patyaṃ mama bhavitā lagnapañcamādhiśau |

bhajato yadītthaśālaṃ tatraivādbe bhaven nūnam \|

yadi vā mitho grhagatau syātām cet saṃtatis tad api|

vācyā tasmin varṣe śubhayogād anyathā na punaḥ\|

lagnapaputrādhipatī na paśyataś cen mitho bhavanamūrtam |

krūrayutīkṣaṇamuthaśilam anayos tat saṃtatir na syāt \|

yadi sutapatir vilagne lagnapacandrau sute 'thavā syātām |

tat tvaritam eva vācyā savilambam naktayogena $\|$

dviśarīre ca vilagne śubhayutaputre dvyapatyagarbho 'sti |

yadi lagnapaputrapati pumkhețau tat suto garbhe \|

atha candraḥ puṃrāśau pumgrahakrnmuthaśilas tadāpi sutạ̣|

horāsvāmī puruṣaḥ puṃrāśau cet tadāpi sutagarbham|

pūrvoditamiśratve sūrye pumkhețasamśrite putraḥ|| iti |

atha pañcamabhāvasthitānāṃ sūryādīnāṃ phalāni padmakośe |

dineśe sutasthe sutāingeșu pị̂̄ā

svabuddheś ca hānir vivādo janānām |

bhavec chokamohādi cāngeșu rogo

dhanārtiś ca bhūpād bhayaṃ taddaśāyām ||

sutasthānago rātrināthah svabuddhyā

jayam mitrapakṣāc ca lābham karoti |

sutāingeșu pị̄̂a bhavet pāpadrșțe

sutasyāpi lābham yadā saumyadrșțah ||

1-14 samarasiṃhah ... iti] om. B N 2 'patyam] apatyam G 3 bhajato] bha * to K; bhavato T M 7 yutīkṣaṇa] yutīkṣā K T M 9 tat] om. K T M \| vācyā] vācyam K T M 10 ca vilagne] caiva lagne K T M $\quad$ 12-13 sutah ... tadāpi] om. K T M 17 svabuddheś] subuddheś B N G 18 mohādi ... rogo] mohādikāṃge surāgo K T M 19 dhanārtiś ca] dhanārjjita G || bhūpād] bhūyād B N G 20 suta] sukha G 22 dṛțte] dṛ̣țaḥ B N; dṛșțas K T M 23 lābhaṃ] saukhyam G

8-13 yadi ... garbham] Cf. PT 2.26-29 16-19 dineśe ... daśāyām] TPK $1.5 \quad 20-23$ suta ... dṛștah] TPK 2.5 
[And] Samarasiṃha [says in the Tājikaśāstra]:

'Will I have progeny in this year?' If [a client asks thus and] the rulers of the ascendant and the fifth [house] partake of an itthaśäla, it will certainly happen in that very year. Or if they should both occupy each other's domicile, then too progeny should be predicted in that year from a benefic configuration, however, not otherwise. If the ruler of the ascendant and the ruler of the fifth house do not aspect each other's house [or] body, [but] they are joined to, aspected by, or in mutthaśila with malefics, ${ }^{61}$ then there will be no progeny.

If the ruler of the fifth house should be in the ascendant, or the ruler of the ascendant and the moon in the fifth house, then [progeny] should be predicted soon; with delay [if they are connected] by a nakta configuration. If the ascendant is a double-bodied [sign] and the fifth house is joined by benefics, there is a twin pregnancy. If the ruler of the ascendant and the ruler of the fifth house are male planets, then a son is in the womb. Or if the moon is in a male sign and makes a mutthasila with a male planet, then too there is a son. If the ruler of the hour ${ }^{62}$ is male, in a male sign, then too there is pregnancy with a son. If the above [criteria] are mixed, [but] the sun is joined to a male planet, there is a son.

Next, the results of the sun and other [planets] occupying the fifth house [are described] in [Tājika] padmakośa [1.5, 2.5, 3.5, 4.5, 5.5, 6.5, 7.5, 8.5]:

If the sun occupies the fifth house, [the native's] children will suffer in their bodies; there will be loss of one's reason, quarrels with people [in general], grief, confusion and so on, illness in the body, loss of wealth, and danger from the king in its period.

Occupying the fifth house, the moon makes triumph through [the native's] own intelligence and gain on account of his friends; if it is aspected by malefics, [the native's] children will suffer in their bodies, [but] when it is aspected by benefics, [it makes] gain of a child. ${ }^{63}$

61 Or: 'in mutthaśila with malefics by conjunction or aspect'.

62 Or, possibly, of the ascendant, as the Greek loanword hora may mean either.

63 Meaning that the native will have a child in that year, or, less likely, that an existing child gains something. 
sutānām prapīdā kuje pañcamasthe ripūnām vivādo bhaved vyagratā ca | svabuddher vināśs bhavec cāgnighātah saśophodare guptapịdābdamadhye \| sutabhavanagataś cet somaputrah sutānām

prabalasukhakarah syād arthaläbhapradaś ca|

bhrtajanasukhakārī hemasasyāmbarāṇām sukham api nrpapakṣān mitrapakșājjayaś ca \| sutasthānago devamantrī sutānām pravrddhim svabuddhyā jayo hāyane 'smin | ripūnām vināśam sukhānām ca bhogāms tathā gohiranyāmbarāptim karoti \| sutānām pravrddhir bhrgau pañcamasthe bhayakleśacintāpadām vai vināśam | ripūnạ̄̄n vināśam tathā varșamadhye mahābhogavantam dhanā dhyam karoti $\|$ sutagatạ sutahānikarạ śanir bhavati codarapịdanakaștadạ | viphalatābahutāpakaro bhaven nrpabhayam prakaroti ca hāyane \| svabuddher vināśam sutasthānagaś ced dhimāmśso ripuḥ saṃtateh pịdanam ca | svakìyodare vāyubādhām dhanārtim tathā sarvathā kleśacintām karoti $\|$ manitthah |

putraruk kāminīkaștạ̣ vighātaṃ cāpi mū dravyanāśạ̣ sveștaduḥkham varșe pañcamage ravau \| strīsukhaṃ vijayaṃ mānaṃ rājapüjā dhanāgamam | sadbuddhiṃ saṃtateh saukhyam yadā putropagaḥ śaśi $\|$

1 sutānāṃ] sutāṃ B N 3 svabuddher] subuddher B N; om. G || vināśo] nāśo G || cāgnighātah] cātmaghātaḥ G; cāpi ghātas K T M 4 4 saśophodare] saśokodare B N K T M 6 sukha] svakha K 7 bhṛtajanasukhakārī] bhṛtakajanasukhaṃ syād G K T M \| hemasasyā-] dehaśayyā- G KT M 8 nụpa] pitṛ G \| mitra] mātṛ G 10 pravṛddhiṃ] pravṛddhị̣ G; pravṛddhis K T M 11 sukhānāṃ ca] sukham cāpi G K T M \| bhogāṃs] bhogas B N; bhogan K T M 14 bhaya] bhayạ̣ B N 18 viphalatā] vikalatā G K T M 20 saṃtateḥ] sạ̣tatih K T 21 svakīyodare] svakāyodare G || bādhāṃ] pịdāạ G 24 vighātaṃ] vighātaś

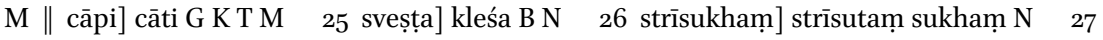
saukhyaṃ] prāptiṃ G || yadā putropagaḥ] paṃcamopagatạ̣ G

1-4 sutānāṃ ... madhye] TPK 3.5 $\quad 5^{-8}$ suta ... ca] TPK 4.5 9-12 suta ... karoti] TPK 5.5 13-16 sutānāṃ ... karoti] TPK $6.5 \quad 17-18$ suta ... hāyane] TPK 7.5 $\quad 19-22$ sva ... karoti] TPK 8.5 
If Mars occupies the fifth, there will be suffering to children, conflict with enemies, agitation, loss of one's reason, injury from fire, ${ }^{64}$ and secret suffering from a stomach tumour in that year.

If Mercury occupies the fifth house, it will make great happiness from children and give gain of wealth. It makes happiness from servants, happiness from gold, grains and clothes, ${ }^{65}$ and triumph on account of the king and of friends. ${ }^{66}$

Occupying the fifth house, Jupiter makes increase of children and triumph through one's intelligence in that year; destruction of enemies, enjoyment of pleasures, and gain of cattle, gold and clothes.

If Venus occupies the fifth, there is increase of children; it banishes fear, suffering, anxiety and misfortune, causes the destruction of enemies and makes [the native] rich in wealth and possessed of great pleasures in [that] year.

Occupying the fifth house, Saturn makes loss of children and gives the evil of stomach pains; it will make futility ${ }^{67}$ and much suffering, and brings about danger from the king in [that] year.

If occupying the fifth house, Rāhu causes the loss of one's understanding, suffering to children, affliction to [the native's] own stomach from [the humour of] wind, harm with regard to wealth, and likewise all manner of anguish and anxiety.

[And] Maṇitthah [says]:

There is illness to children, evils to wife, injury, bewilderment, destruction of property, suffering to loved ones ${ }^{68}$ in a year when the sun occupies the fifth.

When the moon occupies the fifth house [it makes] happiness from women, triumph, honour, reverence from the king, acquisition of wealth, a good mind, and happiness from progeny.

64 Text witness $\mathrm{G}$ reads 'suicide', K T M simply 'injury'.

65 Text witnesses G K T M read 'from the body, beds and clothes'.

66 Text witness $G$ reads 'on account of the father and of the mother'.

67 Text witnesses G K T M read 'mutilation'.

68 Text witnesses B N read 'anguish and suffering'. 
putrārtį̣ kāminūkaștam vyādhiś caivodare nṛ̣ām |

durmatị svajanair vādaḥ pañcame bhüminandane \|

jāyāputrasuḥrtsaukhyaṃ mānam bhūpālasambhavam |

prāpyate buddhito dravyaṃ pañcame śaśinandane \|

sadbuddhih saṃtatiprāptih saukhyam lābho bhaven nṛnām |

mantravidyādijam saukhyam pañcamasthe surārcite \|

jāyāputrādikaṃ saukhyam sadbuddhir vibhavāgamam |

mantropadeśe kauśalyam pañcame bhrgunandane \|

jāyāputravirodhaś ca vigraho 'nyajanaih saha |

jațhare vātajā bādhā pañcame sūryanandane \|

sutāsaukhyạ̣ vyathāprāptir durmatir vairinigrahaḥ|

viyogaḥ svajane pị̂a à saimhikeye tu pañcame \|

iti pañcamabhāvavicārah ||

atha șașṭhabhāvavicārah | tatra șașțhabhāve kiṃ cintanīyam ity uktaṃ caṇdeśvareṇa |

asvāsthyatāsphoțagavoștradāsakrūrograkarmāparakrtyaśǟkāḥ| yuddhāritanmātulamāhișādyaṃ rogo vicintyo ripusamjñabhāve \|

1 putrārtiḥ] putrārtin K T $\quad 2$ vādaḥ] vairaṃ G 3 putra] putro K T 4 buddhito dravyaṃ] sanmatih puṃsām $\mathrm{G} \quad 5$ bhaven ṇ̣nām] bhavebhṛnāṃ N $\quad 6$ mantravidyādijaṃ] ișțamitrakṛtam G $\quad 7$ sadbuddhir] sadbuddhi K T M $\quad 8$ mantropadeśe] vidyāvijñāna G || bhṛgunandane] bhṛguje nụnāṃ G 9 jāyāputravirodhaś ca] jāyāpatyasuhṛtkașțam $\mathrm{G}$ K T M \| vigraho 'nyajanaị̣ saha] dușțabuddhir dhanakșayạ̣ G K T; dușțabuddhir dhanakșayam M 10 jațhare vātajā bādhā] udare vātapīdā ca G K T M \| sūrya] ravi G K T M 11 sutā-] putra G KT M || vyathā] suta G KT M \| nigrahaḥ] vigrahah KTM 12 viyogaḥ] niyataṃ G K T M || svajane] jațhare G K T M 16 asvāsthyatā] āsvāsthyatā G 17 māhiṣādyaṃ] māhiṣāạhyam B 
There is suffering to children, evils to wife, ailments of the stomach, foolishness and quarrels with one's own people for men if Mars is in the fifth.

There is happiness from wife, children and friends, honour deriving from the king, and goods obtained by understanding, ${ }^{69}$ if Mercury is in the fifth.

Men will have good understanding, gain of progeny, happiness, profit, and happiness from knowledge of incantations and so on, ${ }^{70}$ if Jupiter occupies the fifth.

There is happiness [from] wife, children and so on, good understanding, acquisition of fortune, and skill in instruction in incantations, ${ }^{71}$ if Venus is in the fifth.

There is conflict with wife and children, ${ }^{72}$ discord with other people, ${ }^{73}$ and affliction of the stomach produced by [the humour of] wind, if Saturn is in the fifth.

There is unhappiness from children ${ }^{74}$ suffering of anguish, ${ }^{75}$ foolishness, oppression from enemies, separation and suffering to one's own people, ${ }^{76}$ if Rāhu is in the fifth.

This concludes the judgement of the fifth house.

\subsection{The Sixth House}

Next, the judgement of the sixth house. Concerning that, Candeśvara describes what is to be considered from the sixth house:

Ill health, boils, cattle, camels, servants, harsh and cruel actions, low work, fear, fighting, enemies, one's uncle, buffaloes and disease are to be considered from the sixth house.

\footnotetext{
69 Text witness $\mathrm{G}$ reads 'a good mind for men'.

70 Text witness $\mathrm{G}$ reads 'happiness caused by friends and loved ones'.

71 Text witness $\mathrm{G}$ reads 'skill in learning and wisdom'.

72 Text witnesses G K T M read 'evils to wife, children and friends'.

73 Text witnesses G K T M read 'an evil mind and loss of wealth'.

74 Text witnesses G K T M read 'happiness from children'.

75 Text witnesses G K T M read 'gain of children'.

${ }_{76}$ Text witnesses G K T M read 'constant pains in the stomach'.
} 
atrāpi vicāraḥ pūrvavat | atha yogāḥ jīrṇatājike |

varșeśvare śanau șașthe pāpākrānte ca vakrịi | samnnipātākșirogāsrgjvaragulmādisambhavaḥ\| gurāv evampvidhe vātarogậ sakamalo bhavet | varșe kambūlage jīve rogālpatvam vinirdiśet $\|$

bhaume 'py evam raktarogah pittam arke tathāvidhe | evamvidhe himāmśau ca kapharogo bhaven nṛ̣ām || evamvidhe budhe vātapradhāno roga eva hi evampvidhe bhrgau pittarogaḥ śukras tathāvidhaḥ \| nararāsigataś cet syāt kapharogakarah smṛtah | varșeśah pāpayukto 'rko dvādaśe drșțiśúladạ \|

tājikabhūṣaṇe tu vakriṇo 'bdeśasya śaner yatra kutra sthitasya saṃnipātarūpam phalam uktam |

vilomagāmīyadi mandagāmī svāmī sa varșe kurute tridoșam ||

tājikatilake |

varșādhipe ravisute kila vakrabhuktau

syāt saṃnipātarudhirāmayapị̄anam ca \|

vāmanena tu janmalagneśānāṃ śanigurubhaumānāṃ șaș̣thagānāṃ phalam uktam |

śanau janmavilagneśe varșe vakrini șașțhage |

tridoșapịdā lagneśe gurau varșe ripusthite $\|$

pāpākrānte vātapị̣̂a hy evam raktottharuk kuje |

evam pāpārdite saumye vātapīdā bhṛśam bhavet \|

2 vakriṇi] vikriṇi K T 3 rogāsrọ] rogo 'ș̣k G 5 rogālpatvaṃ] rogāllpạ̣ G 6 rogaḥ] yogaḥ G \| tathāvidhe] tathābhidhe B N G 7 vidhe] vidhau G $\|$ nụnām] bhṛnāṃ N 8 vidhe] vidhadhe $\mathrm{N} \|$ eva] ṇava $\mathrm{N} \|$ hi] ca $\mathrm{G} \quad 9$ rogah] saigah $\mathrm{G} \quad 13$ uktam] om. K T M 14 mandagāmī] mañgalāmī K; mañgagāmi T; hy angagāmī M $\quad 15$ tilake] pi add. $G \quad 20$ janmavilagneśe] janmani lagneśe $\mathrm{N} \quad 21$ sthite] sthitau $\mathrm{N}$

14 viloma ... doșam] TBh 4.49 
Here, too, judgement is [to be made] as before. Now, [these] configurations [are given] in the Jirnatäjika:

If Saturn as ruler of the year is in the sixth, beset by malefics and retrograde, compounded illnesses, eye disease, bleeding, fever, abdominal tumours and so on are produced. If Jupiter is thus, there will be disease of [the humour of] wind and jaundice; [but] if Jupiter forms a kambüla in the year, one should declare the illness to be a minor one. If Mars is thus, there is illness of the blood; [disorder of] bile if the sun is thus, and if the moon is thus, men will have illness of phlegm. If Mercury is thus, the illness is mainly of [the humour of] wind. If Venus is such, there is illness of bile; [but] if Venus, being such, should occupy a human sign, it is said to make illness of phlegm. The sun as ruler of the year joined to a malefic in the twelfth gives pain in the eyes.

But in Täjikabhüșaṇa [4.49], the result of Saturn as ruler of the year being retrograde, wherever it is placed, is said to take the form of compounded illnesses:

If Saturn in retrograde motion is ruler, it makes [disorders of] the three humours in [that] year.

[And] in the Täjikatilaka [it is said]:

If Saturn as ruler of the year is in retrograde motion, there will be compounded illnesses and suffering from ailments of the blood.

And Vāmana describes the results of Saturn, Jupiter and Mars, [respectively], as rulers of the ascendant of the nativity occupying the sixth [house of the revolution]:

If Saturn, ruling the ascendant of the nativity, occupies the sixth in the year, being retrograde, there is suffering from the three humours. If Jupiter, ruling the ascendant, occupies the sixth house in the year, beset by malefics, there is suffering from [the humour of] wind. If Mars is thus, there is illness produced by blood; if Mercury, afflicted by malefics, is such, there will be much suffering from [the humour of] wind. 


\section{yādavo 'pi |}

janustanūpe dhișaṇe 'bdașaḍhe krūrārdite vāyubhavo vikārạ̣ | evaṃ kuje kāmalaroga ukto hastotthapị̂āpi ca hāyane 'smin \| evam ravau dvādaśage 'kṣiśülam șaḍhe sacandre 'pi ca pittarogah | tathaiva śukre ripuge nrrrāśau krūrārdite śleșmabhayaṃ mrrtiś ca \| evam vidhau syāt kapharuk tathaiva jĩe pāpadrșțe pavanotthabādhā $\mid$

\section{hillājaḥ |}

janmalagneśvarah pāpo varșādhīśena vīkșitah | kșutadrștyā rogakarah sapāpo mrtyudāyakah \| pāpagrahājanmakāle kendragā varșaveśane | lagnagā rogadā rogasadma pāpayutam tathā $\|$ varșe janmani vā lagne svagrhādyadhikāratah | raver vā bhümiputrasya divase 'bdapraveśatah $\|$ jvarapịdā saumyadrsțe lagne tu sukham ādiśet | rātrijanmani candre 'rkān nirgate vrddhim āgate \| kujetthaśālìvarșe ca candro rogavināsadah | śanïthaśâlī rogasya vrddhido vāhni janmani $\|$ krșnapakșe ca bhaumetthaśālavān rogado vidhuḥ| roganāśakaro mandetthaśálād abdaveśane \| janmakāle candraputre bhrguputre ca nirbale | varșe tu ketusahite tadābdam nikhilam gadah $\|$ abdalagnam ca muthahā tannāthau pāpamadhyagāh | sarve mrtyukarāḥ proktā nyūnā rogakarāh smṛtāḥ \|

2 tanūpe] tanūne $\mathrm{G} \quad 4$ șaḍbhe] șașțhe $\mathrm{M} \|$ sacandre] sacaṃdro B N 5 bhayaṃ] bhavaṃ B N || mṛtiś] mṛtiñ K T M 10 grahā] grahāj K T 11 yutạ̣] yute B N 12 svag̣̣hādy] sag̣̣hādy K T || adhikārataḥ] scripsi; adhikārakaḥ B N G K T M 13 praveśataḥ] praveśanaḥ B N 17 vāhni] vanhi B K T; vahni N M 18 vidhuh] viduḥ N; vithuḥ G 22 tannāthau] scripsi; tannāthạ̣ B; tannāthāḥ N G K T M || madhyagāḥ] mavyagāḥ N 23 nyūnā roga] nyūnāḥ pāpa $\mathrm{G}$

2-6 janus ... bādhā] TYS 12.52-54 
[And] Yādava [says in Tājikayogasudhānidhi 12.52-54]:

If Jupiter as ruler of the ascendant of the nativity is in the sixth sign in the year, afflicted by malefics, there is a disorder produced by [the humour of] wind. If Mars is thus, there is said to be the disease of jaundice, and also suffering arising from the hands, in this year. If the sun is thus [but] occupying the twelfth, there is pain in the eyes; if it is in the sixth sign with the moon, there is a bilious disease. If Venus similarly occupies the sixth house in a human sign, afflicted by malefics, there is danger from phlegm and death. If the moon is thus, there will be illness of phlegm; if Mercury similarly is aspected by malefics, affliction arising from [the humour of] wind.

[And] Hillāja [says]:

The ruler of the ascendant of the nativity being a malefic, aspected by the ruler of the year with a kșuta aspect, causes illness; being with [another] malefic, it gives death. The malefic planets occupying angles at the time of the nativity and occupying the ascendant in the revolution of the year give illness, [if] the lot of illness is likewise joined to malefics. If the sun or Mars has authority of domicile and so on in the ascendant of the year or of the nativity, and the revolution of the year takes place by day, there is suffering from fever; but if the ascendant is aspected by benefics, one should predict well-being.

If, in a nocturnal nativity, the moon has gone out from under the sun and begun to wax, the moon having an itthaśa la with Mars in the year alleviates illness; [but] having an itthaśāla with Saturn, it aggravates illness. In a diurnal nativity in the dark fortnight, ${ }^{77}$ the moon having an itthaśāla with Mars gives illness; [but] by an itthaśāla with Saturn in the revolution of the year, it alleviates illness. ${ }^{78}$

If Mercury or Venus is weak at the time of the nativity and joined to Ketu in the year, then there is illness throughout the year. The ascendant of the year, the munthaha and their rulers all placed between malefics are declared to cause death; [if] less, they are said to cause ill-

77 That is, under a waning moon.

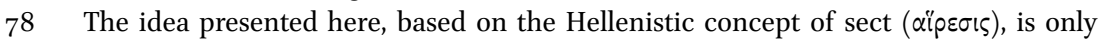
half-understood. The moon's aspects with the nocturnal Mars are considered more benevolent if occurring at night and when the moon is waning; those with the diurnal Saturn are preferred by day and when the moon is waxing. See the end of Sahl's Introduction (transl. Dykes 2019a: $71 \mathrm{f}$.), which is the likely source of this Tājika doctrine. 
sūtau șașthagate bhaume varșe lagnasthite rujah | janmābdayor budhe śukre balayukte 'bdalagnatah \| șașthage rāhupucchāḍhye tadābdam nikhilam gadaḥ| șașthādhipo yadā lagne tadā śatrur bhaved dhruvam \|

vāmanah |

janmakāle gurusitau syātām yadrāśisaṃyutau | varșakāle ca tadrāśigate bhaume 'stamāgate \| bhavanti pițakāsítam tathā śîtalikās tanau| tadrāśige budhe sendau gandamālādirug bhavet \| rāhau saptagate tasmin nikhilābdam gado bhavet | vibalo janmalagneśo yadi șaștham samāśritạ $\|$ ripudrsțah pāpayuto 'stamito dìrgharug jvarah | janmalagneśavan munthāsamādhisó 'pi kaștakrt | janmalagneśavat punyasahameśo 'pi kaștadah || lagneśe vibale lagne krūramadhyagate rujah | kanyātulāmithunage șașțhe śukre kapho bhavet \| yatra janmani śukrạ̣ syāt tadrāśau șașțam āśrite | varșalagnād ravisute rogạ̣ smarakrto bhavet $\|$ aștamasthe gurau pāpayute lagnagate kuje | mūrchā syāc candrayukpāpe lagnasthe 'ñgaryathä bhavet \| janmany atha kujo yatra rāśau varșavilagnage | pāpekșite raktapịdā tasmin syāc chubhavīkșite | pị̣ā svalpātha yoge ruk șașthalagneśayor bhavet \| janmany ārkih sthito yatra rāśau varșe 'tha lagnage | tadrāśau śaninā drșțe śleșmaśîtoṣnarug bhavet ||

1 șașthagate] kaștamga N $\quad 2$ janmābdayor] janmābdape B N 3 pucchāḍhye] pucchādye N G 8 piṭakāśîtaṃ] pițakāśîrta G; pițakāḥ śîtam M 9 sendau] seṃdrau G \| mālādirug bhavet] mālādir udbhavet G; bhālādirug bhavet $\mathrm{K}$ 10 saptagate] saptamage K T M \| tasmin] smit $\mathrm{N} \quad 11$ vibalo] vivalī B; vicalī N \| samāśritaḥ] samāśriḥ N 13 janma ... kașțakṛt] om. B N || samādhisso] sadmādhīó G 15 lagneśe] lagneśo B N 18 ravisute] raviyute B N G; raviḥ sute T 23 șașţha] șașțhe K T M $\quad 24$ ārkih sthito] ārkiyuto B N 25 śaninā] śaśinā G || śleșma] mleșma B 
ness. ${ }^{79}$ If Mars, occupying the sixth in the nativity, occupies the ascendant in the year, there is illness. If Mercury or Venus, endowed with strength in the nativity and the year, ${ }^{80}$ occupy the sixth from the ascendant of the year, joined to the tail of Rāhu, then there is illness throughout the year. When the ruler of the sixth is in the ascendant, then [the native] will surely have an enemy.

[And] Vāmana [says]:

If Mars, having set [heliacally] at the time of the year, occupies the sign which Jupiter and Venus had joined at the time of the nativity, boils, heat, and small-pox appear in the body. If Mercury occupies that sign along with the moon, there will be disease like inflammation of the glands in the neck. If Rāhu occupies the seventh in that [sign], there will be illness throughout the year.

If the weak ruler of the ascendant of the nativity resorts to the sixth, aspected by enemies, joined to malefics, [or heliacally] set, there is long-lasting illness and fever. The ruler of the munthaha or of the year also makes evils like the ruler of the ascendant of the nativity. The ruler of the sahama of fortune also gives evils like the ruler of the ascendant of the nativity. If the weak ruler of the ascendant is in the ascendant, placed between malefics, there is illness. ${ }^{81}$ If Venus in the sixth occupies Virgo, Libra or Gemini, there will be [a disorder of] phlegm.

If Saturn resorts to the sixth from the ascendant of the year, in the sign where Venus was in the nativity, there will be disease caused by lovemaking. If Jupiter occupies the eighth joined to a malefic, and Mars occupies the ascendant, there will be fainting. If a malefic joined to the moon occupies the ascendant, there will be agitation of the limbs. Further, if the sign where Mars was in the nativity occupies the ascendant of the year, aspected by malefics, there is suffering from blood; [but] if it should be aspected by benefics, the suffering is mild. And if the rulers of the sixth and the ascendant are configured, there is illness. Further, if the sign where Saturn was placed in the nativity occupies the ascendant in the year, and that sign is aspected by Saturn, there will be illness of phlegm, cold and heat.

79 That is, if only some of these points are besieged by malefics.

8 o All text witnesses agree on this unexpected criterion.

81 The ruler of the ascendant in the ascendant itself would (at least in many cases) occupy its domicile and so be considered strong. Possibly the author is thinking of the ruler of the ascendant of the nativity occupying the ascendant of the revolution. 
atra tejaḥsiṃhena samarasiṃhena ca śanidṛștịm vinā rūkṣādirogāḥ proktāḥ | śanidṛșțau tu yāpyatā nāma kutsito roga uktah | samarasiṃhạ̣ |

janmaśanisthānagate lagne rūkṣoṣnasítarogāḥ syuḥ| śaninā drșțe cāsmin saviśeșam yāpyatā bhavati șaștheśe varșabhujā lagnabhujā vātha muthaśile rogạ̣ | janmany adhikāriṇi vā sabale varșe ca ketubudhayukte | tad atīva gado jñeyas tasmin varșe samaste 'pi $\|$

tejaḥsiṃhạ| |

janmāninapaś ca vibalo yadi śatrugo 'bde krūrārdito ripudrśāstamitaś ca rukkrt |

ittham matā iha vilagnabhuginthiheśā $v$

angārtidau himakaraś ca mano'rtidāȳ̄ $\|$

dagdhas tanau malinadrin malino 'ngarukkrt

krūradvayāntar udupe 'stanijeśavīrye | sampūrnapāpadŕśi dīrgharujo bhavanti rogādikam ca bhayam atra bhabhuktamānāt $\|$

ayam arthah | șașṭhabhāvasyāṃśādi bhuktaṃ svalpaṃ tadā rogabhayam apy alpaṃ | bhuktāṃśānām ādhikye rogādhikyạ̣ jñeyam ity arthaḥ | viśeșam āha samarasiṃhạ |

\footnotetext{
1 tejah] bejaḥ N 2 dṛștau] dṛ̣țe B N || yāpyatā] scripsi; jāpyatā B N G K T M || kutsito] kutsita K T M 3 gate] gato G 4 yāpyatā] scripsi; jāpyatā B N G K T M 5 șașțheśe] șașțheśa $\mathrm{M}$ || rogaḥ] ciragaḥ $\mathrm{K} \mathrm{M}$; rāgaḥ $\mathrm{T} \quad 7$ tad atīva] tadātīva B N 11 matāv] gatāv $\mathrm{B}$ N || inthiheśāv] iṃthaheśāv B N 12 angārtidau] aṃgārktidau N; añgārtikṣau K; añgārtido M || 'rtidāyī] rtidoyam B N 13 rukkṛt] rukkṛd M 14 krūra] ūru M || dvayāntar] dvayānār K 16 bhabhukta] mabhukta G; bhamukta T 17 apy] om. K T M 18 ādhikye] ādhiko K || rogādhikyaṃ] om. N $\quad 18-644.12$ viśeșam ... iti] om. B N

9-16 janmā- ... mānāt] DA 22.9-10

2 samarasimhah] All text witnesses place this attribution in the middle of the following quotation (after bhavati), presumably an early error. The relatively free, moraic āryā metre is more easily mistaken for prose than syllabic metres.
} 
On this [matter], Tejaḥsiṃha and Samarasiṃha state that [even] without the aspect of Saturn, there are illnesses such as dryness; but with Saturn aspecting there will be the vile disease called yapyata.${ }^{82}$ Samarasimha [says in the Tājikaśāstra]:

If the ascendant [of the year] occupies the place of Saturn in the nativity, there will be illnesses of dryness, heat and cold; if this [sign] is also aspected by Saturn in particular, there is a chronic condition. If the ruler of the sixth is in a mutthaśila with the ruler of the year or with the ruler of the ascendant, there is illness. If it has authority in the nativity or is strong, and is joined to Ketu and Mercury in the year, then it is to be understood that there is serious illness for that entire year.

[And] Tejaḥsiṃha [says in Daivajñālaṃkrti 22.9-10]:

And if the ruler of the ascendant in the nativity is weak and occupies an inimical [sign] in the year, afflicted by a malefic with an inimical aspect and being [heliacally] set, it makes illness. So, too, are the ruler of the ascendant [of the year] and the ruler of the inthih $\bar{a}$ considered to give bodily suffering; and the moon [similarly afflicted] gives mental suffering. A tarnished [planet] burnt in the ascendant, aspected by [another] tarnished [planet], makes illness in the body. ${ }^{83}$ If the moon is between two malefics, the strength of its ruler having set, ${ }^{84}$ and perfecting an aspect with [another] malefic, there will be long-lasting illnesses and danger of disease and so on in this [year] according to the [degrees] traversed in the sign.

The meaning is as follows: [if] only few degrees and so on of the sixth house have been traversed, then the danger of disease, too, is small. If more degrees have been traversed, the [danger of] disease should be understood to be graver: this is meant. Samarasiṃha states a special rule [in the Tãjikaśāstra]:

82 This statement suggests that Balabhadra did not understand the meaning of yāpyatā (given in all text witnesses as jäpyatā), which is the amenability of a condition to palliative care only, not to cure. I am indebted to Dominik Wujastyk for explaining the concept to me. In the following quotation I have translated yāpyatā as 'chronic condition'.

83 In section 6.9 below, Balabhadra glosses 'tarnished' (malina) as 'malefic'.

84 This phrasing probably refers to the domicile ruler of the moon having lost its strength by setting heliacally. 
asmin varșe māndyam maraṇam vā vīkșya varșalagnam atha | gatadarśapūrṇimāyām lagnam ca tadīśvarau vīkṣyau \| ete catvāro 'pi hi śubhadrșțāḥ saumyamuthaśilāś cet syuḥ| drșțā ravicandrābhyām tasmin varṣe na māndyaṃ syāt || krūrahataih śaśisūryādrșțair grahadhātuto māndyam| șașthagrhasthe khețe taddoṣenaiva rogasambhütih \| catvāro 'py aśubhahatāś candro dagdho yad eka eșāṃ ca | nidhaneśena muthaśile tadāgrahād bhūyasā maraṇam \| yadi nidhaneśạn krūras tad rogād antareṇa bahu mrtyuḥ| balahīne punar asmin śubhetthaśāle ca no vācyạ̣ \| pūrvoktāś catvāro yadi șașthādhïsamuthaśilakṛtaḥ syuh | tad dīrghataram māndyam śīghre 'smin śāmyati tvaritam || iti |

varṣatantre |

caturthe 'ste ca muthahā kṣutadrsṣtyā śanīkșitā| śūlapị̣ā pāpakhagair drṣțe tat parināmajam \|

atra paripākāvasthāyāṃ śūlaṃ pariṇāmākhyam |

janmaṣașthādhipe bhaume varșe șașthagate rujā|

krūretthaśāle vipulā śubhadrgyogatas tanuh \|

rogakartā yatra rāśāv amśse syād anayor balī|

tat sthānam tasya rogasya jñeyaṃ rāśisvarūpatah \|

1 viksṣya] tīkșya K $\|$ atha] apy evam K T; apy evam M 3 ete] scripsi; te G K T M 6 gṛhasthe] grahasthe $\mathrm{G} \|$ doṣeṇaiva] doṣe rogeṇaiva $\mathrm{K} \quad 7$ yad eka] padaika $\mathrm{K}$ T; yadaika $\mathrm{M} \|$ eșāṃ] reșāñ M 8 muthaśile] scripsi; muthaśilaṃ G T; muthaśila KM || tadāgrahād] tadād G; svadāgehāṃ K; svaddāgehāṃ M \| bhūyasā maraṇam] scripsi; bhūyasāṃ maraṇaṃ G T; bhūpasāsmaraṇaṃ K; bhūyasā smaraṇaṃ M 9 rogād] doṣād KM 11 kṛtah] kṛtās K T M 14 kṣutadṛsțyā] kṣuddṛṣtyaā ca G 16 paripākā] paripāko K T || śūlaṃ] om. B N 17 șașṭhādhipe] șașțhyādhipe K 18 śubha] prubha N || yogatas tanuḥ] yogatạ̣ stanuḥ B; yogakas tanuh K T

14-15 caturthe ... pariṇāmajam] VT 10.11 17-18 janma ... tanuh] VT 10.16 19-20 roga ... svarūpatah] VT 10.15 
'Will there be illness or death in this year?' [If a client asks thus], one should examine the ascendant of the year and then the ascendant at the previous new or full moon and their [respective] rulers. ${ }^{85}$ If these four should be aspected by benefics, having mutthaśila with benefics, and aspected by the sun and moon, there will be no illness in that year. By [their being] afflicted by malefics and unaspected by the sun and moon, there is illness according to the element of the planet. If a planet occupies the sixth house, illness is produced from its humour.

If all four are afflicted by malefics and the burnt moon is one of them, in a muthaśila with the ruler of the eighth house, death mostly occurs by the force of that [planet]. If the ruler of the eighth house is a malefic, then death often occurs without [any preceding] illness. ${ }^{86}$ If, however, that [planet] is weak and in an itthaśäla with a benefic, [death] is not to be predicted. If the four aforementioned [points] should form a mutthasila with the ruler of the sixth, then there is a prolonged illness; [but] if that [planet] is fast [in its course, the illness] quickly abates.

[And] in Varșatantra [10.11 it is said]:

[If] the munthahā is in the fourth or the seventh [house], aspected by Saturn with a kssuta aspect, there is suffering from pain; if [the house is] aspected by [several] malefic planets, that [pain] is caused by transmutation.

Here, pain [occurring] in the process of digestion is called '[pain of] transmutation'. [Continuing from Varșatantra 10.16, 15:]

If Mars, ruling the sixth [house] in the nativity, occupies the sixth in the year, there is illness. If [Mars] has an itthaśäla with a malefic, [the illness] is grave; by an aspect or joining with a benefic, slight.

The stronger of the sign and [ninth]-part in which the [planet] causing illness should be [placed] is to be known as the place of that illness, according to the nature of the signs.

85 Although Greek- and Arabic-language sources do use the lunations as significators in matters of life and health, it is typically the planetary rulers of the part of the zodiac where the lunation takes place that are considered, rather than the ascendant at the time.

86 Or, possibly, 'during an illness'. 
atra saṃjñādhyāye rās̄īnāṃ kaphavātapittādikaṃ rūkṣoṣnassîtādikaṃ ca proktam asti | tadavalambena rogasthitir ity arthạ | yādavaḥ |

munthābdalagnaṃ ca khalārditam cet tatpau vivīryau khalagau ca vāstam | yātau śaśi krūrakhagāntarastho vyathā tathā dīrgharujo bhavanti ||

lagnasthe khalakhecare sahimagau kutrāpi dehe vyathā

sūtau vā ripuge kuje 'bdatanuge rogo januhkendrage |

pāpe 'smims tanuge gado 'tha śubhatā vā janmagejyośano-

bhe 'bde lagnagate 'rkarāśigakuje syuḥ śitalādyā rujạ̣ \|

balojjhite ca sadmani pranaștake ca nāyake |

yadā tadā gadakșayo nṛ̣ām bhavet samābhave \|

samarasimhah |

indau bhümau gagane svagṛe vā muthaśile svagrhagena|

vakrāstasūryaraśmipraveśavarjyeṇa cārogyam \|

lagneśendvoḥ saumyetthaśālato roganāśanam vācyam |

vakre tu tatra khețe bhūyo 'pi gadaḥ samudayeta \|

atha șașțhabhāvasthitānāṃ arkādīnāṃ phalāni padmakośe |

ripūnām vināśo rujā mātṛpakṣe

ravau șașthasamsthe sukhāptir janānām |

nrpān mitrapakșājjayaś cārthalābho

bhaved dravyalābhaḥ kraye vikraye ca \|

1 atra] ata B 2 tadavalambena] tadavaleṃna N 3 cet] yat B N \| tatpau] patyau B N; tad yau G || ca vāstam] pavāpte B N; thavāstaṃ G 4 vyathā] scripsi; nyathā B N G; yathā K T M \| tathā dīrgha] om. B N 5 vyathā] om. B N 6 ripuge] ripuga B N \| kuje] om. B N \| tanuge] janugo B N $\|$ rogo] om. B N 7 śubhatā] śubha B N; śubhadā K T M $\|$ janmagejyośano] scripsi; janmagejyośanor B N G K T; janmagejyo śaner M 8 'bde lagna] bdalagnem B || syuḥ] syāḥ B; śyaḥ K 9 sadmani] sanmaniprani K; sadyani T; sanmati M 10 bhave] bhavet M 11-15 samarasiṃhạ ... samudayeta] om. B N K M 12 svagṛhagena] svagṛhegena T 15 samudayeta] scripsi; samudayet G T 18 sukhāptir] sukhāmir N 19 jayaś] jayaṃ B N G 20 ca] vā G K T M

3-4 munthā ... bhavanti] TYS $12.61 \quad 5^{-8}$ lagnasthe ... rujah] TYS 12.59 9-10 balojjhite ... bhave] TYS $12.63 \quad$ 17-20 ripūnām ... ca] TPK 1.6

4 vyathā] The emendation is supported by MSs TYS1, TYS $3 . \quad 7$ janmagejyośano] The emendation is supported by MSS TYS 1 , TYS 3 . 
Concerning this, [the nature] of the signs [with respect to the humours of] phlegm, wind, bile and so forth, and [with respect to being] dry, hot, cold and so forth, has been described in the chapter on definitions. That is, the place of the disease [is determined] with the help of those [qualities]. [And] Yādava [says in Täjikayogasudhānidhi 12.61, 59, 63]:

If the munthaha and the ascendant of the year are afflicted by malefics, their rulers weak and evilly placed or [heliacally] set, and the moon placed between malefic planets, there is agitation and long-lasting illness.

If a malefic planet occupies the ascendant along with the moon, there is pain somewhere in the body; or if Mars, occupying the sixth house in the nativity, occupies the ascendant in the year, there is illness. If a malefic, occupying an angle in the nativity, occupies the ascendant in this [year], there is disease; but if the sign occupied by Jupiter or Venus in the nativity occupies the ascendant in the year, it is well. If Mars [in the year] occupies the sign of the sun, there are diseases such as smallpox.

When the lot [of illness] is bereft of strength and its ruler is corrupt, then men will waste away with illness in the course of the year. ${ }^{87}$

[And] Samarasiṃha [says in the Tājikaśāstra]:

If the moon is in the fourth or tenth house, in its domicile or in a mutthaśila with [a planet] that occupies its own domicile and is not retrograde, [heliacally] set or entering the sun's rays, there is good health. From an itthaśála of the moon or the ruler of the ascendant with a benefic, the vanquishing of an illness is to be predicted; but if that planet is retrograde, the disease may manifest again.

Next, the results of the sun and other [planets] occupying the sixth house [are described] in [Tājika] padmakośa [1.6, 2.6, 3.6, 4.6, 5.6, 6.6, 7.6, 8.6]:

If the sun occupies the sixth, there is destruction of enemies and illness on the mother's side; men attain happiness; there is triumph on account of the king and friends, and gain of wealth; and there will be gain of goods through buying and selling.

87 Or, possibly but less probably, 'the illness of men will waste away'. 
aristhānago rātrinātho ripūṇām vivādam virodham ca netrānigapị̣̂ām | vyayam vyagratām guptacintām tanoti kalatrāngapịdām karotīha varșe || kujaḥ șașthagah śatrunāśaṃ karoti svapakșāj jayam mitrapakșāc ca lābham | hayānāṃ ca saukhyaṃ bhaved añganānām sukham hāyane syād daśāyām ca tasya \| ripusthe budhe vairinām vai vivādo bhaved añganānām ca kaștạ̣ karoti vyayạ̣ vyagratām sve śarīre ca kaștạ̣ kaphārtim mahākaștam apy atra varșe \| kaștạn ripūṇām ripugah surejyo bhayārtidoșān kurute narāṇām | bhāryāngapiḍ̄m atha netrarogam juarātisāram ca karoti varșe \| aristhānago hāyane daityamantrī janānām vivādo ripor bhītikașțam | bhaved guptacintā varāningaprapịdā śiro'rtiś ca netrodare pịdanam ca \| șașthasthito bhavati bhūdhanalābhakārī sūryātmajo nrpasamam manujạ̣ prakuryāt | dhānyāmbarāṇi vipulāni karoti nityam kïrtervivardhanam athārtivināśanam ca $\|$ ripor vināśam yadi saiṃhikeyah șașțhasthitah syān nrpatulyakārī| gobhūhiranyāmbaralābhadaś ca dhanāptikrd duhkhavināśanaś ca \|

maṇitthah

annāgamaṃ tathā dhairyaṃ rājamānam ripukșayam | saukhyam kalatraputrādi șașthe pradyotano yadi $\|$ vātaśleșmādikā bādhā vidveșo bāndhavaih saha| ripucaurodbhavā pịdà varșe șașțasthite vidhau ||

6 tasya] tasyāṃ B N 12 ca karoti] prakaroti K T M 13 vivādo] vivādaṃ G 15 bhavati] om. B N K T M 20 dhanāptikṛd] dhanāptichad N \| vināśanaś] vināśanaṃ G; vināśanañ K T 23 pradyotano] pradyotane B N G

1-2 ari ... varșe] TPK 2.6 3-6 kujạ ... tasya] TPK 3.6 7-10 ripusthe ... varșe] TPK 4.6 11-12 kaștam ... varșe] TPK 5.6 $\quad 13-14$ ari ... ca ca $\left.^{2}\right]$ TPK $6.6 \quad$ 15-18 șașțha ... ca] TPK 7.6 19-20 ripor ... ca ${ }^{2}$ ] TPK 8.6 
Occupying the sixth house, the moon brings about disputes with enemies and opposition [from them], suffering from the eyes and limbs, loss, agitation, and secret anxiety; it makes [the native's] wife suffer from her body in this year.

Mars occupying the sixth makes destruction of enemies, triumph on one's own account and gain on account of friends; there will be happiness from horses and happiness from women in its period within the year.

If Mercury occupies the sixth house, there will be disputes with enemies, and it makes evils for women, loss, agitation, evils in [the native's] own body, disorders of phlegm and great evils in this year.

Occupying the sixth house, Jupiter makes evils from enemies and danger, suffering and harm for men; it makes [the native's] wife suffer from her body [and makes] eye disease, fever and dysentery in this year.

[If] Venus occupies the sixth house in the year, there will be disputes with [common] people, the evil of danger from enemies, hidden anxiety, suffering in the chief member, ${ }^{88}$ headache and suffering from the eyes and stomach.

Occupying the sixth, Saturn brings gain of land and wealth and makes a man equal to a king; it always makes plentiful grains and clothes, increase of renown and destruction of suffering.

There is destruction of enemies if Rāhu occupies the sixth; it will make [the native] equal to a king, give gain of cattle, land, gold and clothes, make acquisition of wealth and destroy suffering.

[And] Manittha [says]:

There is acquisition of food, fortitude, ${ }^{89}$ honour from the king, destruction of enemies, and happiness [from] wife, children and so on, if the sun is in the sixth.

There are disorders of [the humours of] wind, phlegm and so on, discord with kinsmen, and suffering caused by enemies and robbers, if the moon occupies the sixth in the year.

88 Often referring to the head, but given the fact that the head is mentioned immediately afterwards, the 'chief member' here is probably the penis or genitals more generally, an appropriate signification for Venus.

89 Or: 'wisdom'. 
iștasvajanataḥ saukhyam dhanaläbhaṃ ripukșayam | pramodaṃ nrpater mānam șașțhasthānagate kuje \| śatrupakșavivrddhim ca vivādam svajanaị saha| śarīre rogajām pịdām kuryāt saumyas tu șașțagaḥ \| ripuvrddhim athodvegam dhananāśạ̣ balakșayam |

iștasvajanavidveșam șașthe devapurohite \| vātaśleșmodbhavā bādhā kșayotpattir dhanakșayam | mahābhayam gṛhe kaștam varșe șașthagate bhrgau \| dehe saukhyam dravyavrddhih prasādo bhümipālatah | strīputrajanitam saukhyam varșe șașthagate śanau \| nrpaprasādam ārogyam dhanaläbho ripukșayah $\mid$ kalatraputrajam saukhyam varșe șașthe vidhuṃtude ||

iti șașṭhabhāvavicārah ||

atha saptamabhāvavicāraḥ | tatra saptamabhāve kiṃ vicāryam ity uktam caṇ̣eśvareṇa |

vastukrayasvāsthyavanijyavādāh kāmo jayo dāsakalatracauryāḥ | nivrttisuśreyagamāgamādyam kalatrabhāve tu vicāryam etat \||

atrāpi pūrvavad vicāraḥ | atha yogāḥ | yādavaḥ |

smaragate 'bdapatau sabale site yuvatisaukhyam atīva guror drśá | sabalabhūmisutena vilokite bahuraso hy ubhayoś ca parasparam \|

1 ișta] ișțaḥ B N G 3 pakșa] pakșe T M 4 saumyas tu] saumyosta G $\quad 5$ athodvegam] athobdega $\mathrm{G} \quad 7$ vāta] vātaḥ K T M || śleșmodbhavā] śleșmabhavā K T M 11 prasādam] prasāda M 13 bhāvavicāraḥ] bhāvaḥ B N K T M 14 vicāryam] vicāraṇīyam G K T M 16 vādāḥ] scripsi; vāda B N G K T M \| cauryāḥ] cauryyaṃ G 18 atha] atra B N 19 'bda] ddavṛ̦sa $\mathrm{N}$ a.c.; vṛșa N p.c. \| patau] pate $\mathrm{G}$ 2o sabala] sakala $\mathrm{G}$

19-652.3 smara ... āśutah] TYS 12.64-66 
There is happiness from loved ones and one's own people, gain of wealth, destruction of enemies, delight, and honour from the king, if Mars occupies the sixth house.

Mercury occupying the sixth will make enemies multiply, make disputes with one's own people and suffering in the body due to illness.

If Jupiter is in the sixth [it makes] enemies multiply, agitation, loss of wealth, waning of strength, and discord with loved ones and one's own people.

There are disorders of [the humours of] wind and phegm, the arising of consumption, loss of wealth, great danger, and evils in the home, if Venus occupies the sixth.

There ar pleasures of the body, increase of goods, favour from the king, and happiness caused by wife and children, if Saturn occupies the sixth in the year.

There is favour from the king, good health, gain of wealth, destruction of enemies, and happiness from wife and children, if Rāhu is in the sixth in the year.

This concludes the judgement of the sixth house.

\subsection{The Seventh House}

Next, the judgement of the seventh house. Concerning that, Candeśvara describes what is to be judged from the seventh house:

Buying goods, health, trade, arguments, [sexual] desire, victory, servants, wives, robbers, disappearance, splendour, coming and going and so forth: this is to be judged from the seventh house.

Here, too, judgement is [to be made] as before. Now, configurations; [and] Yādava [says in Tājikayogasudhānidhi 12.64-66]:

If a strong Venus as ruler of the year occupies the seventh house, there is abundant happiness from women by the aspect of Jupiter; if [Venus] is aspected by a strong Mars, there is great mutual desire between the 
śaśijadrș̣tiyute ca tathā site prathamayauvanayā parayoṣayā | ravijadrșțiyute 'pi ca vṛddhayā smaravaśo hy avaśo ramate naraḥ\| guruyute 'pi ca nūtanavallabhā bhavati tatra ca saṃtatir āśutaḥ|

vāmanaḥ |

janmalagnādhipe varșe lagnāt saptamage sati | udite sabale caiva dārasaukhyam prajāyate \| śukro janmani yadrāśau varșe varșeśvaro yadi | tadrāśau saptamasthe 'pi puṃsaḥ parinayas tadā \|

tājikasāre śukrāspade lagnagate vivāhaḥ ity uktam |

lagnāstanāthayor yoge vivāhāptih prajāyate | șașthādhipe śubhe șașthasthite prāptih striyo bhavet || vivāhasadmādhipatau sabale syād grhasthatā| tasminn astagate bhāryānāśo bhāvādhipe tathā $\mid$

tejaḥsimhah |

dagdhe site yuvatijātam asaukhyam āhuh śukrāspade tu yuvativyasanam kuje syāt | jīve ca haddapavivāhapatau vivāho bhaume 'bdape śanidrśā tu viparyayaḥ syāt \|

5 varṣe] varșa G K T M $\quad 6$ saukhyaṃ] sausaukhyam $\mathrm{N} \quad 7$ varṣeśvaro] lagneśvaro $\mathrm{G} \quad 9$ tājikasāre] tu add. G || śukrāspade] śukrasya deva B N \| vivāhaḥ] vivāhatyu T 10 nāthayor yoge] nāthayoge 'pi M 11 șașţhādhipe] șașțhādhipa B N \| śubhe] śubhair B N || șașțha] dṛsțe B N || prāptiḥ] prāmị̣ N $\quad$ 12-13 vivāha ... tathā] om. B N K T a.c. M 16 tu] om. K M || yuvati] yuvatijaṃ M 18 śani] śaśi G T || viparyayah] paviryeyaḥ $\mathrm{N}$

9 śukrā- ... vivāhah] TS $214 \quad 15$ dagdhe ... āhuh] DA 23.8 $\quad 16$ śukrā ... syāt] DA $23.9 \quad 17$ jīve ... vivāho] DA 23.10 18 bhaume ... syāt] DA 23.11 
two [lovers]. Likewise, if Venus is joined to the aspect of Mercury, a man in thrall to passion inevitably sports with another's wife in her first youth, and, if joined to the aspect of Saturn, with an old woman. And if [Venus] is joined to Jupiter, he gets a young wife and quickly has progeny from her.

[And] Vāmana [says]:

If the ruler of the ascendant in the nativity occupies the seventh [house] in the year, [heliacally] risen and strong, happiness from the wife results. If, in the year, the ruler of the year ${ }^{90}$ occupies the seventh in that sign where Venus was in the nativity, then a man's wedding takes place.

In Täjikasāra [214] it is said: 'If the ascendant [of the year] occupies the place of Venus [in the nativity], marriage takes place.' [Vāmana continues:]

If the rulers of the ascendant and the seventh house are joined, it results in marriage taking place. If the ruler of the sixth is a benefic and occupies the sixth, one will obtain a wife. If the ruler of the lot of marriage is strong, [the native] will become a householder; [but] if it is [heliacally] set, he loses his wife, and likewise if the ruler of the [seventh] house [is so].

[And] Tejaḥsiṃha [says in Daivajñālaṃkrti 23.8-11]:91

If Venus is burnt, they say unhappiness on account of women [results]; if Mars [in the year] is in the place of Venus [in the nativity], there is a passion for women; if Jupiter is ruler of the hadda and ruler of the seventh house, there is marriage; but if Mars is ruler of the year, by the aspect of Saturn ${ }^{92}$ [on it] there will be the opposite.

9o Text witness $\mathrm{G}$ reads 'the ruler of the ascendant'.

91 Each quarter $(p \bar{a} d a)$ of the stanza as given here corresponds to a different verse in independent witnesses of the Daivajñālam krti.

92 Text witnesses G T read 'the moon'. 
jīrṇatājike |

pañcārisaptadaśame dvitrilābheșu śîtaguḥ|

śukrekșito 'tha jōvena śubham syāt pramadābhavam |

śeșekșitah striyā sārdham śatrutvam jāyate dhruvam ||

janmalagnāt saptameśe 'bdapaśukrayutekșite |

strīsukham bahulaṃ tatra varșe bhavati niścayāt $\|$

śukro janmani yadrāśau sa rāsị̣́ kendrakonagaḥ|

guruṇā sahito varșe kāntakāntāsukhapradậ \|

lagnahaddādhipạ śukrasthāne kendratrikonagah |

vivāhasahameśo vā varșe kāntāsukhapradạ \|

10

bhaume varșeśvare sukradrște syād vanitāgamah |

śukre varșeśvare bhaumadrște lābhah striyo bhavet |

sūtau vābde śukrabhaumadrșțe strīsahame tathā $\mid$

varṣatantre |

lagnāstanāthayor itthaśāle strīlābham ādiśet |

svāmidrștam strīsahamam śukradrșțạn vivāhakrt || naștendau śukrapadage maithunam svalpam ādiśet | janmaśukrarkṣago bhaumah strīsukhotsavakrd balī ||

naștalakṣaṇam uktam vāmanena |

krūrākrāntaḥ krūrayutaḥ krūradrșțaś ca yo grahaḥ|

viraśmitām prapannaś ca sa vinașto budhaih smṛtah || iti |

2 saptadaśame] saptamaśame $\mathrm{K} \quad 3$ bhavam] bhayam M 4 śeșekșitah] saumyekșitaḥ B N 8 kānta] kāṃtaḥ K T M 13 strīsahame tathā] strīlābham ādiśet B N 20 yutaḥ] yuktaḥ K T M 21 viraśmitāṃ] viraśmirtaṃ $\mathrm{N}$

15 lagnāsta ... ādiśet] VT $11.4 \quad 16$ svāmi ... vivāhakṛt] VT $11.11 \quad$ 17-18 nașțendau ... balī] VT 11.5 
[And] in the Jìrnatājika [it is said]:

[If] the moon is in the fifth, sixth, seventh, tenth, second, third or eleventh house, aspected by Venus or by Jupiter, there will be good on account of women; [but if the moon is] aspected by the rest [of the planets], enmity with a woman certainly results.

If the ruler of the seventh from the ascendant of the nativity is joined to or aspected by Venus as ruler of the year [in the revolution], then certainly there is much happiness from women in that year.

The sign in which Venus was in the nativity occupying an angle or trine in the year, joined by Jupiter, bestows happiness between husband and wife. ${ }^{93}$ The ruler of the hadda of the ascendant occupying an angle or trine in the place of Venus [in the nativity], or the ruler of the sahama of marriage [being so placed] bestows happiness from the wife in [that] year.

If Mars as ruler of the year is aspected by Venus, [the native] will acquire a wife; if Venus as ruler of the year is aspected by Mars, he will win a woman; likewise if the sahama of wife in the nativity or in the year is aspected by Venus and Mars.

[And] in Varșatantra [11.4, 11, 5 , it is said]:

In case of an itthaśăla between the rulers of the ascendant and the seventh house, one should predict gain of a wife.

The sahama of wife, aspected by its ruler [and] aspected by Venus, causes marriage.

If the moon, being corrupt, occupies the place of Venus, one should predict little intercourse. A strong Mars occupying the sign [occupied by] Venus in the nativity makes a celebration of happiness from women.

The definition of being corrupt is stated by Vāmana:

The planet that is beset by malefics, joined to malefics and aspected by malefics, and has lost its rays [by proximity to the sun] is said by the wise to be corrupt. ${ }^{94}$

93 Or 'from husband or wife', implying that the native whose annual revolution is being considered could be either male or female.

94 Cf. the similar definition quoted from Caṇdeśvara in section 1.5. 
adhikāripadasthe 'rke strībhyo vyākulatāniśam |

inthihādhikrtasthāne gurudrștyā vivāhakṛt \|

adhikāripade pañcādhikārirāśau |

inthihārārkiyugdyūne krūrite sahame strìyāh |

strīputrebhyo bhavet kaștam pāpadrștyā viśeșatah \|

sūtau dyūnādhipah śukro 'bde dyūne balavān bhavet |

lagneśenetthaśālaś cet strīlābham kurute sukham \|

sūtau dyūnādhipe varșe strīsadmeśe striyāh sukham |

janmāstapenthihānāthavarșeśāh khe dyune tathā $\|$

yādavaḥ |

janmeśvare varșapatau sitena syān munthaśīle sukham eva nāryāḥ | vivāhasadmādhipatau ca lagnahaddādhipe vā sabale sitena | yutekșite vā janișașțanāthe 'bde șașthayāte śubhadrgyute tat || vivāhagehe khaladrștiyukte tatpe vinaște vibale ca duhkham | strïjam tathaivābdamade kuje 'pi duhkham bhavet strïbhavam abdakāle \| sūryāstage krūrayutekșitenthä syāt saptame strīsutaduhkhadātrī | savirryakhețāspadage 'stasūrye strìduḥham ijyekșaṇatah sukham ca \| devejyaśukrekșitakevalenthā strīgā ca yoșāsukhalābhadā ca |

1 adhikāri] adhikāra $\mathrm{G} \|$ padasthe] padesthe $\mathrm{G} \|$ vyākulatāniśam] vyākutālaniśaṃ N $\quad 12$ patau ca lagnahaddādhipe] patītthaśāle yutekșite B N 14 khaladṛști] khalașți N || vinaște] vilagne G T; vanișțhe K; 'vivāhaḥ M \| vibale] bahulaṃ M $\quad 15$ made] pade B N $\quad 16$ sūryāstage] sūryestage G K T M || yutekșitenthā] yutekșite tathā K T M || saptame] saptamī G 17 khețāspadage 'sta] khețasya dṛg astu B N 18 kevalenthā strīgā] kevalesyātrgā K; kevale*ātrigā T; kevale syāt strīgā M

1-2 adhikāri ... vivāhakṛt] VT $11.7 \quad 4-7$ inthihā ... sukham] VT 11.8-9 8-9 sūtau ... tathā] VT 11.1211 janmeśvare ... nāryāḥ] TYS $12.69 \quad 12-13$ vivāha ... tat] TYS $12.70 \quad$ 14-18 vivāha ... $\left.\mathrm{ca}^{2}\right]$ TYS $12.72-74$

12 patau ... haddādhipe] The reading of G K T M is supported by MSs TYS1, TYS 3. 
[Continuing from Varșatantra 11.7:]

If the sun occupies the place of [a planet] in authority, there is constant trouble from women; [but] by the aspect of Jupiter on the place

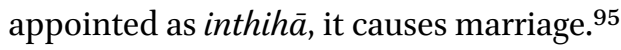

'In the place of [a planet] in authority' [means] in the sign of [one of] the five [planets] in authority. [Continuing from Varșatantra 11.8-9, 12:]

If the seventh house is joined by the inthih $\bar{a}$, Mars, and Saturn, and the sahama of wife is afflicted, there will be evil to wife and children, particularly by an evil aspect. If Venus as ruler of the seventh house in the nativity should be strong and [placed] in the seventh house in the year, [and] there is an itthaśäla with the ruler of the ascendant, it makes gain of a wife with ease.

If the ruler of the seventh house in the nativity rules the lot of wife in the year, there is happiness from the wife; likewise [if] the ruler of the seventh house in the nativity, the ruler of the inthiha, and the ruler of the year are in the tenth or seventh house.

[And] Yādava [says in Tājikayogasudhānidhi 12.69, 70, 72-74, 67, 77]:

Should the ruler of the nativity [or] the ruler of the year be [in] mutthaślla with Venus, there is happiness from the wife.

And if the ruler of the sahama of marriage or the ruler of the hadd $\bar{a}$ of the ascendant is strong and joined to or aspected by Venus. If the ruler of the sixth [house] in the nativity occupies the sixth in the year, that [result is the same].

If the seventh house is joined to the aspects of malefics and its ruler is corrupt or weak, there is suffering caused by the wife. Likewise, if Mars is [placed] in the seventh house of the year, there will be suffering arising from the wife in the course of the year. The inthiha joined to or aspected by malefics in the seventh [house], opposite the sun, gives suffering from wife and children. If the sun in the seventh house occupies the place of a strong planet, there is suffering from the wife, but by the aspect of Jupiter [on the sun], happiness. And the inthiha occupying the seventh house, aspected only by Jupiter and Venus, gives gain of happiness from wife. 
jananaśukragarāśigate janustanupatau sabale pariṇāyanam \| yuvatidhāmapater bhrgujād api yuvatijaṃ ca śubhāśubham ìrayet |

tājikasāre |

madapatir madagah sabalo yadā khalakhagaị sahito na ca vīkșitaḥ | munivarair gaditam bahulaṃ sukham yuvativargabhavam vividham tadā $\|$

hillājaḥ |

dyūnendau lagnape vāpi kanyālābhah suniścitam |

dyūnapo lagnagaś candradrșto bhāryāprado dhruvam ||

svarkșe śukre candrayukte drșțe vā yoșid āpyate |

sūryo vā balavā läbhe krūrakanyāprado matah \|

samarāśau candrasitau trikoṇe svanavāmeśake |

balinau lagnaputrasthau bhäryālābhakarau matau |

saumyaị kendratrikonasthair dyūne drșțe 'nganāptikrt ||

lagnage saptamādhïśe bhartrādeśakarī priyā |

saptame lagnape bhāryādeśakārī patir bhavet ||

lagneśo lagnago jāyādhiśạ̣ saptamasaṃsthitạ̣ |

dvau vā lagnāstagau varșe jāyāprïtisukhapradau \|

lagneśástapayoh snehadrștyā saukhyam mitho vadet |

krüradrștyā kalim drșțer abhāve madhyamam vadet \|

1 śukraga] śukra N || janustanu] janu G $\quad 2$ yuvatijaṃ] yuvatinaṃ K M $\quad 5$ vividhaṃ] bahulaṃ B N 7 lagnape vāpi] lagnage vāpi B N; lagnapetāpi K; lagnapenāpi M 8 candradṛsțo] caṃdrașțo N || prado] sukham B N 9 dṛsțe] dṛșțer M || āpyate] āspadi M 10 lābhe] lābho G || krūra] krūrạ̣ B N 13 dyūne dṛșțe] scripsi; dyūnadṛște B N G K M; dyūnaș̣te T || 'nganāptikṛt] ṃganāmikṛt N 14 bhartrā-] bhartā- B N K T

1 janana ... pariṇāyanam] TYS $12.67 \quad 2$ yuvati ... îrayet] TYS $12.77 \quad 4-5$ mada ... tadā] TS 181 
If the ruler of the ascendant of the nativity is strong and occupies the sign occupied by Venus in the nativity, [the native's] wedding [takes place].

From the ruler of the seventh house and from Venus one should predict the good and evil arising from women.

[And] in Tājikasāra [181 it is said]:

When the ruler of the seventh house occupies the seventh house, being strong, not joined to or aspected by malefic planets, abundant and manifold happiness is declared by great sages to arise on account of women.

[And] Hillāja [says]:

If the moon [is in] the seventh house or the ruler of the ascendant [is therein, the native] will surely win a maiden. The ruler of the seventh house occupying the ascendant, aspected by the moon, certainly grants a wife. If Venus is in its domicile joined to the moon or aspected [by it], a woman is won; but the sun strong in the eleventh house is considered to grant a cruel maiden. The moon and Venus strong, occupying the ascendant [or] the fifth house in an even sign, in their [mūla]trikona ${ }^{96}$ [or] own ninth-part, are considered to cause gain of a wife. If the seventh house is aspected by benefics occupying angles and trines, it causes gain of a wife.

If the ruler of the seventh occupies the ascendant, the wife does her husband's bidding; if the ruler of the ascendant is in the seventh, the husband will do his wife's bidding. The ruler of the ascendant occupying the ascendant and the ruler of the seventh house occupying the seventh, or the two occupying the ascendant [or] the seventh house [together] in the year bestow affection and happiness from one's wife. From an aspect of love between the ruler of the ascendant and the ruler of the seventh house, one should declare mutual happiness; from an evil aspect, quarrel; in the absence of an aspect, one should declare [marital happiness] to be middling.

96 Or, less likely: 'in a trine', that is, in signs $120^{\circ}$ distant from each other, such as the rising sign and the fifth sign. 
sabale dhanabhāve ca bhāryādravyam labhen naraḥ | sabale chidrabhāve tu bhāryā bhartrudhanam labhet | varșeśvare gurau dyūne vyavahārād dhanāptayah || veśyānurāgo madape vinaște nīcage 'pi vā | krūrānvite ca madape parayoșid avāpyate \| saptame krürakhacarah śubhadrsțivivarjitah | bhāryāmaranadah prokto vinașțo vāstanāyakaḥ \|

cūḍāmaṇau |

yuddham bhāvi na vā varșe lagneśasaptamādhipau | śatrū syātāṃ tadā yuddhaṃ bhavatīti suniścitam || lagnam lagnasya pūrvaṃ vā yadi pāpasamanvitam | tadā ghoraṃ bhaved yuddham pāpo vekșeta pārśvakam || lagnāstanāthayor yoge raṇaṃ dīrgham samādiśet | mande vakre ca sabale bahuyuddham bhavet tad̄̄ $\|$ svagrhoccagate bhaume daśamasthe syād ranam pracuram | lagnasthe madhyataram dyūnasthe sadmani pracuram || lagnadyūnapatī pāpau pāpāṃśasthau tu yuddhadau | tāv eva vakritau kendre șașthapo vā raṇapradạ̣ $\|$ lagneśe dyūnage 'ntye vā varșe syāt tu parājayah | lagnasthe vāstape șașțhe śatror eva parājayạ \|| lagne krüre jayah prașțh saptame vidvișo jayaḥ | mürtau krūre jayaḥ proktaḥ krūradrștyā paräjayaḥ \|

2 bhartṛ] bhartur $\mathrm{G} \quad 4$ nīcage] nīcago K T $\quad 5$ yoșid] yoṣit $\mathrm{K} \quad 6$ śubha] śukra $\mathrm{G} \quad 9$ lagneśa] lagneśe K T M 12 pārśvakam] yorśvakaṃ B N 15 svag̣̣hocca] svagṛhe ca B N \| daśamasthe] daśame G 18 vakritau] vakriṇau K T M 20 lagnasthe] scripsi; lagnāste B N; lagneste G K T M || eva] iva K M 21 lagne krūre] krūre lagne G 
If the second house is strong, a man will acquire his wife's wealth; but if [his] eighth house is strong, the wife will acquire her husband's wealth. If Jupiter as ruler of the year is [placed] in the seventh house, there is acquisition of wealth from business.

There is attachment to prostitutes if the ruler of the seventh house is corrupt or occupies its fall, and if the ruler of the seventh house is joined to malefics, [the native] gets another's wife [as his mistress]. A malefic planet in the seventh, bereft of the aspect of benefics, ${ }^{97}$ is declared to bring death to [the native's] wife; or the ruler of the seventh house being corrupt [does the same].

[And] in the Cüdāmaṇi [it is said]:

'Will there be war or not in [this] year?' Should the ruler of the ascendant and the ruler of the seventh [house] be enemies, then it is certain that there will be war. If the ascendant or [the house] prior to the ascendant ${ }^{98}$ is joined by malefics, then there will be a terrible war, [or] should a malefic aspect [either] flank..$^{99}$ If there is a configuration of the rulers of the ascendant and the seventh house, one should predict a long-lasting war; if Saturn and Mars are strong, then there will be a great war. If Mars, placed in its domicile or exaltation, occupies the tenth [house], there will be a great war; if it occupies the ascendant, middling; if it occupies the seventh house [and] the lot, a great one. ${ }^{100}$ The rulers of the ascendant and the seventh house being malefics, occupying malefic divisions, bring war. The two retrograde, or the ruler of the sixth [house] in an angle, bring about war.

If the ruler of the ascendant occupies the seventh house or is [placed] in the twelfth house, there will be defeat in [that] year; but if the ruler of the seventh house occupies the ascendant or the sixth, there is defeat for the enemy. If there is a malefic in the ascendant, there is victory for the querent; in the seventh, victory for the enemy. Victory is declared if there is a malefic in the ascendant, [but] by a malefic aspect, defeat.

97 Text witness G reads 'of Venus'.

98 That is, the twelfth house.

99 That is, the second and twelfth houses.

100 Or: 'if the lot occupies the seventh house'. In either case, it is not clear which lot is meant. 
saṃdhiṃ kuryāt suhrddrșțir lagneśāstapayor mithaḥ|

aye 'pi sabale samdhir vibale vigraho bhavet $\|$

udayacaturthaị krūraiḥ saptamadaśamasthitais tathā saumyaị̣|

vijayo bhavati hi yuddhe dyūnodayagaih śubhaiś cāpi $\|$

caralagne śubhayukte saṃdhānaṃ bhavati bhümipālānām |

daśamopagataih saumyair vittaṃ dattvā paro yāti $\|$

hāyanasindhau |

yadi krūragraho varșe jāyeśam lagnapaṃ dhruvam | na paśyati tadā tatra naștam vismrtam āpyate $\|$ yasmin rāśau bhavec candras tadrāser adhipena cet | dr'śyate candramā varșe tadā nașțam ca labhyate \| dhanapo nihssrtah sūryād udito bhavati sphuțah | tadā ca vismṛtam naștạn prāpyate niścayād dhanam \| hibukāstāntarālasthair grahaih śubhaphalapradaị | yātrāsiddhiṃ vijānīyād aśubhair naiva nirdiśet | saptame svāmisaumyā dhye drșțe vā syān nivartanam \| carātmakasya pramadāhvayasya bhāvasya pāpekșaṇahīnitasya | varșapraveśe prabhaven niṿ̛ttih pravāsayātasya ca nānyathā syāt ||

atha saptamabhāvasthitānāṃ sūryādīnāṃ phalāni padmakośe |

kalatre 'rkayukte kalatrāngapīdā 20 svakìyāngapièā tathā taddaśāyām | śiro'rtiś ca mārgād bhayam vai vivādo gude pādayoh pịdanam varșamadhye $\|$

1 suhṛddṛșțir] suhṛddṛșți B N; sudṛșțir G 3 udaya] upacaya B N || caturthaih] caturtheh B N || saptama] sapta B N 4 hi] om. B || dyūnodayagaiḥ śubhaiś] dyūnodayagaiś B; dyū-

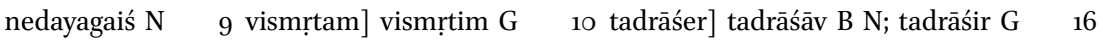
nivartanam] nivartate K T; nivarttate $\mathrm{M} \quad 17$ pāpekșaṇahīnitasya] pāpagrahadṛgyutasya $\mathrm{G}$ T; pāpekșaṇadūṣitasya M 18 varșa] varșe M || yātasya] jātasya K T M || nānyathā] nāyathā B 19 saptama] om. G

20-23 kalatre ... madhye] TPK 1.7 
A friendly aspect between the ruler of the ascendant and the ruler of the seventh house will bring reconciliation. If the eleventh house is strong, there will be reconciliation; if weak, conflict. By malefics [occupying] the ascendant and the fourth [house], and benefics occupying the seventh and the tenth, there is victory in war, and also by benefics occupying the seventh house and the ascendant. If the ascendant is a movable [sign] and joined by a benefic, there is a reconciliation of kings; by benefics occupying the tenth, the enemy leaves once [the querent] has given [them] wealth.

[And] in the Hāyanasindhu [it is said]:

If, in the year, no malefic planet aspects the ruler of the seventh house [or] the ruler of the ascendant, then lost [or] forgotten [property] is certainly regained in that [year]. If the moon in the year is aspected by the ruler of the sign in which the moon should be [placed in the nativity], then too lost [property] is found. [If] the ruler of the second house becomes visible, having come out from under the sun and risen [heliacally], then too lost [or] forgotten wealth is certainly regained.

By planets that bestow benefic results occupying the space between the fourth and the seventh house, one should understand successful journeys [to take place; but] by malefics [placed thus] one should not predict it. If the seventh [house] is joined by its ruler and benefics or aspected [by them], there will be a return [for the traveller]. If, in the revolution of the year, the house is of a movable nature [and] called feminine, ${ }^{101}$ free from the aspects of malefics, the return of one who has gone abroad will take place; otherwise it will not happen.

Next, the results of the sun and other [planets] occupying the seventh house [are described] in [Täjika] padmakośa $[1.7,2.7,3.7,4.7,5.7,6.7,7.7,8.7]$ :

If the seventh house is joined by the sun, there is pain in the wife's body, and likewise pain the [native's] own body, in its period; there is headache, danger from travel, dispute, and pain in the anus and in the feet in [that] year.

101 Only Cancer and Capricorn meet both these criteria. 
kalatre śaśān்ko yadā pāpadrșțo

jvaram vātapị̂ām bhayaṃ dāruṇam ca |

kalatrāngakaștam kaphotpattibādhām

sa saumyānvitaś cārthalābham karoti \|

kalatre sthite kșmāsute strīṣu rogam

tathā cātmano mārgato 'tīva kaștam |

bhayạn vairinām vạ vai vivādo janānām

daśā neșțakārī bhaved dhāyane 'smin \|

śaśānkātmaje saptamasthe 'ñganānām

vilāsādisaukhyam bhavaty atra varșe |

pratișțādhikā gohiranyāmbarāptir

jayah sarvadā taddaśāyām tathaiva ||

kalatre surejye kalatrādisaukhyam

janān nirbhayam śatrunāśam karoti |

sukhạ̣ vāhanānām vilāsādikaṃ ca

nrpāl labdhalakșmìr bhaved dhāyane 'smin \|

kalatre bhrgau jāyate hāyaneșu

kalatrādisaukhyam vilāsādikaṃ ca|

ripor nāśanam mānavānām ca saukhyam

bhaved vastrahemādisaukhyam narānām \|

jāyāsthānagato divākarasutaḥ syād añganānām rujo

mārgād bhïtikaraḥ paśoś ca marạ̣ạ̣ rājyād bhayam vyagratām |

kleśānām ca vivardhanam prakurute mithyāpavādam tathā

dehe vāyusamudbhavā ca jațhare pị̂ā bhaved dhāyane \|

vātapramehārtim atho narānāịn guhyendriyārtim ca tamo dyunastham |

vișāgnipịdām ca tathāñganānām kaștaṃ karotīha bhayaṃ narāṇām ||

5 kalatre] kalatra G 6 mārgato 'tīva] mārgataḥ kleśa G 9 'ñganānāṃ] ṃganāṃ N $\quad 11$ -ādhikā go] -ādhikāro G 14 janān] janaṃ B N; jayan K T M 17 bhṛgau jāyate hāyaneṣu] kaviś ced bhaved varșamadhye G \| jāyate] yate N \| hāyaneșu] hāyanesmin KTM 18 kalatrādi] kalatrāṃga G 20 saukhyạ̣ narānām] lābham karoti G 23 prakurute] ca kurute B N $\quad 25$ atho narānāṃ ] athodarārtiṃ G \| dyunastham] munisthạ̣ B N 26 karotīha] karotī B || narāṇām] nụpāṇāṃ G K T M

1-4 kalatre ... karoti] TPK 2.7 5-8 kalatre ... 'smin] TPK 3.7 9-12 śaśāṅkā ... tathaiva] TPK 4.7 13-16 kalatre ... 'smin] TPK 5.7 17-20 kalatre ... narāṇām] TPK $6.7 \quad 21-24$ jāyā ... dhāyane] TPK $7.7 \quad 25^{-26}$ vāta ... narāṇām] TPK 8.7

20 narānām] At this point B N add a half-stanza in the same style and metre as the preceding verses, seemingly an alternative to the one immediately following but not present in independent witnesses of the TPK: kalatre śanir jāyate caiva kașțạ̣ jvaram vātapị̂āạ bhayam dārunam ca. 
When the moon is in the seventh house aspected by malefics, it makes fever, suffering from [the humour of] wind, terrible danger, evil to the wife's body, and disorders from increase of phlegm; joined to benefics, gain of wealth.

If Mars occupies the seventh house, there is illness among [the native's] womenfolk, and also to himself, excessive evil from travel, danger from enemies, disputes with people [in general: its] period in this year brings no good.

If Mercury occupies the seventh house, there is happiness from pleasures with women and so on in this year, great eminence, acquisition of cattle, gold and clothes, ${ }^{102}$ and likewise constant triumph in its period.

If Jupiter is [placed] in the seventh house, it makes happiness from wife and so on, security from people [in general], ${ }^{103}$ and destruction of enemies. There will be happiness from vehicles, pleasures and so on, and riches granted by the king in this year.

If Venus is in the seventh house, in [those] years people meet with happiness from wife and so on, ${ }^{104}$ pleasures and so on, destruction of enemies, and happiness; men will have happiness from clothes, gold and so on.

[If] Saturn occupies the seventh house, there will be illness to womenfolk; it makes danger from travel and brings death of cattle, danger from royal [quarters], agitation, aggravation of suffering, lies and slander; and there will be pains in the body caused by [the humour of] wind, and [particularly] in the stomach, in [that] year.

Rāhu occupying the seventh house makes urinary disease from [the humour of] wind for men, ${ }^{105}$ pain in the private parts, suffering from poison and fire; likewise evil for women and danger for men. ${ }^{106}$

102 Text witness $\mathrm{G}$ reads 'rank, authority, and acquisition of gold and clothes'.

103 Text witnesses K T M read 'triumph and security'.

104 Text witness $\mathrm{G}$ reads 'happiness from the wife's body' (or 'pleasures of the body for the wife').

105 Text witness G reads 'urinary disease from [the humour of] wind and stomach pain'.

106 Text witnesses G K T M read 'danger from kings'. 
manitthah |

vasticakșuhśirorogaị̣ strīpịdā nagarātanam |

varșagas tu yadā dyūne bhāskaraḥ kurute nṛnām \|

strīsukhaṃ nṛpater mānaṃ lābho grāmāntarād bhavet |

vānijyājjalamārgāe ca saptame yadi candramāḥ \|

jāyākaștam tathā hāniḥ pị̣̂ā ātmana eva ca |

deśe bhramśam bhayam asau kuryād bhaumas tu saptame \|

mārgāl lābho ’nganāsaukhyam vānịjyāc ca dhanāgamam |

candrajạ kurute nityam hāyane saptame yadi $\|$

vānijjyād vyavahārāc ca mārgāc caiva dhanāgamam |

strīsukhaṃ rājasanmānam saptame suramantrini $\|$

dayitāputrajạ̣ saukhyaṃ vānijyād vibhavāgamam |

mārgāl lābham pramodạn ca saptame bhrguje nṛnām ||

satatam gamane prïtih suhṛtkaștam dhanakșayah |

pravāsaḥ śatruto bhìtị saptame ravinandane \|

pravāsah pịdanam cānge strīkaștam pavanottharuk|

kațivastau bhavet pìdā saiṃhikeye ca saptame \|

iti saptamabhāvavicāraḥ ||

athāșțamabhāvavicārah | tatrāṣtamabhāve kiṃ cintanīyam ity uktaṃ caṇ̣eśvareṇa |

2 cakṣuḥ] vakṣa G; vakṣaḥ K T M 3 dyūne] dyūno B N G K T 4 mānaṃ] yānaṃ M || lābho] lābhaṃ G 7 deśe] deśa G KT M \| bhayam asau] bhayamāsau N; bhayạ̣ saukhyạ̣ G 8 mārgāl] mārgāc ca G 9 saptame] scripsi; saptamo B N G K T M \| yadi] yadā K T M 12 dayitā] rdāyadā N 13 saptame] saptamo N 14 prītiḥ] bhītiḥ G K T M $\|$ kṣayaḥ] kṣayaṃ B N G K T 15 pravāsaḥ] pravāsaṃ B N G K T \|| ravi] sūrya G 16 pravāsaḥ] pravāsam K T M \| pavanottharuk] pavanosya N 19 cintanīyam] vicāraṇīyam K T M 
[And] Manittha [says]:

When the sun is in the seventh house in the year, it makes suffering to [the native's] wife from illnesses of the abdomen, eyes, ${ }^{107}$ and head, and makes men roam about the town. ${ }^{108}$

There will be happiness from women, honour ${ }^{109}$ from the king, and gain from another village, from trade, and from travel by water, if the moon is in the seventh.

There is evil to the wife, and likewise loss and suffering to oneself: [when placed] here in the seventh, Mars will make roaming through the land and danger.

There is gain from travel and happiness from wife, and Mercury makes constant acquisition of wealth from trade if [placed] in the seventh [house] in the year.

There is acquisition of wealth from trade, business and travel, happiness from wife and honour from the king, if Jupiter is in the seventh.

There is happiness arising from wife and children, acquisition of fortune by trade, gain from travel, and delight for men, if Venus is in the seventh.

There is love of constant wandering, ${ }^{110}$ evil to friends, loss of wealth, living abroad, and danger from enemies, if Saturn is in the seventh.

There will be living abroad, bodily pain, evil to wife, illness arising from [the humour of] wind, and pains in the hip and abdomen, if Rāhu is in the seventh.

This concludes the judgement of the seventh house.

\subsection{The Eighth House}

Next, the judgement of the eighth house. Concerning that, Candeśvara describes what is to be considered from the eighth house:

107 Text witnesses G K T M read 'chest'.

108 Or 'between towns'.

109 Text witness $M$ reads 'a carriage'.

110 Text witnesses G K T M read 'constant danger [or: fear] from wandering'. 
āyur virodho nidhanam carādyam bhedo 'tha śastraughanirūpaṇam ca | vaișamyadurgādikaśatrurodho nadyādisaṃtāraṇanaștarogāh | chidram raṇaṃ bhrātrripuś ca kaștạ̣ vicāraṇīyam nidhane samastam ||

atrāpi pūrvavad vicāraḥ | atha yogāḥ | yādavaḥ |

varșeśe 'vanije 'bale khalahate śastrān mrtir mrtyuge tasmin vahnibhage 'gnibhïr dvipadabhe caurogralokād bhayam | khasthe 'smin nrpater bhayam hibukabhe mātuh pitur mātuläd randhrānyatragate kuje mrtisamam mrtyur na cejyekșaṇāt $\|$ varșatantre abdapabhaumasya yatra kutrāvasthitasya phalam uktam | bhaume 'bdape krūrahate 'yasā ghāto balojjhite | agnibhīr agnibhe krūranarād dvipadabhe mrtį̣ \|

janmāșțanāthena gataujasābde lagnādhināthe krtamūthaśîle | syād alpamrtyuś ca divābdaveśe sārke 'bdape bhüpabhayam mahïje ||

1 carādyaṃ] ca vādyam G T || śastraugha] vastraugha B N; vāstoḥ śca G 3 raṇaṃ] nụnāṃ B N || kașțạ̣] dựțtạ̣ B N K T M 4 atrāpi pūrvavad vicārah] atra vicāraḥ pūrvavat G || yādavaḥ] yādavena B N 6 bhage] mage M || 'gnibhīr] 'gnibhor M || dvipadabhe] dvipada B N; dvipadame M || caurogra] caurāgra N 11 agnibhīr] agnibher K 12 gataujasābde] gataujasobde $\mathrm{B}$ G a.c.; gataujasaubde $\mathrm{N}$; gatembhiheśe $\mathrm{K}$; gateṃthiheśa T; gateṃthiheśe $\mathrm{M}$ ॥ nāthe] nāthena $\mathrm{K}$

5-8 varșeśe ... cejyekșaṇāt] TYS 12.78 $\quad$ 10-11 bhaume ... mṛtiḥ] VT 12.1 12-13 janmā- ... mahïje] TYS 12.79 
Longevity, conflict, death, wandering and so on, division, displaying a multitude of weapons, distress, danger and so on, conflict with enemies, crossing rivers and so on, lost [property], illness, infirmity, battle, brothers' enemies and evils: all [this] is to be judged from the eighth house.

Here, too, judgement is [to be made] as before. Now, configurations; [and] Yādava [says in Tājikayogasudhānidhi 12.78]:

If Mars as ruler of the year is weak and afflicted by malefics, there is death from weapons, if it occupies the eighth house; if it occupies a fiery sign, there is danger from fire; in a human sign, danger from robbers and violent people. If it occupies the tenth house, there is danger from the king; in the sign on the fourth house, from the mother, father, or uncle. If Mars is placed elsewhere than the eighth house, there is [suffering] equal to death, and there is no death if [Mars is] aspected by Jupiter.

[But] in Varșatantra [12.1, these] results are described for Mars as ruler of the year placed anywhere:

If Mars as ruler of the year is afflicted by malefics and bereft of strength, there is a blow with iron; in a fiery sign, danger from fire; in a human sign, death [inflicted] by a violent man.

[Continuing from Tājikayogasudhānidhi 12.79:]

If the ruler of the ascendant has made a mutthasila with the ruler of the eighth house of the nativity, which is bereft of strength in the year, there will be untimely death. ${ }^{111}$ If Mars as ruler of the year is with the sun when the revolution of the year takes place by day, there is danger from the king.

111 The meaning of alpamrtyu (lit. 'little death') is somewhat uncertain. While the present reading is secure for metrical reasons, the word probably originated as a scribal error or folk etymology for apamrtyu in the sense of 'untimely death'; however, something like 'a brush with death' could also conceivably be meant. 
varșatantre tu kujārkayor yoge divase 'bdaveśe nṛpabhayam uktam |

lagnenthihāpatisamāpatayo mrtīsóa

ced itthaśálina ime nidhanapradāh syuḥ|

cet pākariștasamaye mrtir eva tatra

sārke kuje nrpabhayam divase 'bdaveśe \|

krūrakhecaradaśāamaye ca ityādijātakoktadaśāriștẹ varṣe lagnenthihāpati ityādiyogotpattau maraṇaṃ daśāriștāsambhave duḥkham ity arthạ̣ |

ravau janau śukrakamūsarīphe kendre 'bdanāthe nrpabhītirogau| janmārabhe 'bde śaśije 'bdakendre 'bdeśe hi durvarșam idaṃ vadanti || tasmin budhe kevalam aștayāte bhaumāridrștyāpi na śobhano 'bdaḥ| tathāștage jñe sabale kujākșiyukte videśe maraṇam ca bandhaḥ \|

ete yogās tājikasindhāv anyathaivoktāḥ |

śukresarāphasahito janmakāle ca bhāskaraḥ| varșādhikārī kendrastho jvararājarugāptikrt $\|$

bhaumasthāne 'dhikārīnduputre varșe rujas tathā |

budho 'dhikārī bhaumena krūradrșto 'șrgārtidah \|

bhaumayukte budhe sārke videśe bandhanam mritịn || iti |

2 mṛtīśā] mṛtišsaśs B N G; mṛtîsāa K T M 4 samaye] samayo G 6 khecara] khecare B N \| ca] ced G 7 riștāasambhave] rișțasaṃbhave B N; rișțās saṃbhave K 8 śukraka] śukra G 9 kendre 'bdeśe] keṃdreśe B N 10 tasmin budhe] tasmibun dhe $\mathrm{N} \|$ aștayāte] așțapāte M 11 kujākși] kujārki B N 15 -īndu] -īṃduḥ T M || putre] putra T || tathā] tadā N K T M; tanau G 17 videśe] videśaṃ B N K T M

2-5 lagnenthihā ... 'bdaveśe] VT 12.3 6 krūra ... ca] JKP 8.6 || lagnenthihāpati] VT 12.3 $8-11$ ravau ... bandhah] TYS $12.8 \mathrm{o}-81$ 
But in Varșatantra [12.3], danger from the king is declared when Mars and the sun are conjunct in a revolution of the year in the daytime [without Mars ruling the year]:

If the rulers of the ascendant and the inthih $\bar{a}$ and the ruler of the year have an itthaśāla with the ruler of the eighth house, they can bring death: if [the configuration occurs] at a fatal time in the periods [of the planets], there is indeed death. If Mars is with the sun when the revolution of the year is in the daytime, there is danger from the king.

That is, if the configurations [described in the sentence] beginning with 'If the rulers of the ascendant and the inthih $\bar{a}$ ' arise in a year for which fatality from [planetary] periods has been declared in [passages like that] beginning with 'And at the time of the period of a malefic planet' in Jätaka[karmapaddhati 8.6], there is death; in the absence of fatality from the periods, [only] suffering. [Continuing from Täjikayogasudhānidhi 12.8o-81:]

If the sun in the nativity is in a müsarihpha with Venus [and] the ruler of the year is in an angle, ${ }^{112}$ there is danger from the king and illness. If Mercury as ruler of the year is in that sign in the year where Mars was in the nativity, in an angle in the year, they call this an evil year. If that Mercury occupies the eighth [house] alone, with an inimical aspect from Mars, the year is not good. And if a strong Mercury occupies the eighth, joined to the aspect of Mars, ${ }^{113}$ there is death and captivity abroad.

These configurations are described quite differently in the Täjikasindhu:

The sun having an isarāpha with Venus at the time of the nativity and having authority in the year, occupying an angle, brings about fever and consumption. Likewise, if Mercury, having authority in the year, is in the place of Mars, there are illnesses. Mercury having authority [in the year and being] harshly aspected by Mars brings suffering from blood. If Mercury with the sun is joined to Mars, there is captivity and death abroad.

112 Or, possibly: 'If the sun as ruler of the year is in a mūsarihpha with Venus in the nativity [and] in an angle'.

113 Text witnesses B N read 'joined to Mars [and] Saturn'. 
atrobhayor virodhe ete yogāntarā eva jñeyāḥ | varșatantre |

bhaumasthāne 'dhikārīndau guptaṃ nrrpabhayaṃ rujaḥ| mando 'dhikārī khe lohahateh pị̣̂ākaraḥ smrtậ \|

asmin yoge 'șțamasthaś candro jñeya iti yādavaḥ |

janmasthabhaumarkṣagate 'bdaveśe candre 'ștamasthe nṛpapịdanāni $\|$

bhaume 'ștame bhayam vahneh prahāro vā nrrpād bhayam | āre khasthe catuṣpādbhyah päto duhkham rujo 'șjah $\|$

atra prathamayoge hīnādhikāre kuje raviyute 'ștamasthe vahnyādibhayam | dvitīyayoge adhikāriṇi bhaume daśamasthe vāhanāt pāta ity āha yādavaḥ |

hīnādhikāre 'pi kuje 'șțamasthe sārke 'gnibhītir nrrpapịdanāni $\|$ bhaume 'mbarasthe 'py adhikāriṇi syād vāhāt prapātah khalu varșaveśe|

jïrṇatājike |

varșeśvaro guruh pāpadrșțo varșe 'ștamasthitaḥ| dravyahānikaro mando balahīno 'śubhekșitah | varșalagnāt saptamago 'pavādakalikārakah \| lagnāștameśayor itthaśālo mrtyubhayapradah | pāpadrșto 'bdapo jīvo dhanastho dhanahānidah \|

\footnotetext{
1 atro-] tatro- K T M || eva] evaṃ M 4 'șțamasthaś] șțamastha K T M 5 bhaumarkșa] bhaurkșama G 7 khasthe] khaste K T $\quad 11$ veśe] madhye G $\quad 13$ 'șțama] șțame K T M 14 bala] balī G 15 saptamago] saptago K 16 mṛtyu] mṛtyur K T

2-3 bhauma ... smṛtah] VT $12.5 \quad 5$ janmastha ... pị̣anāni] TYS $12.82 \quad 6-7$ bhaume ... 'sụjaḥ] VT 12.6 10-11 hīnā ... veśe] TYS 12.82-83
} 
As the two [sources] conflict, these should be understood to be different configurations. [And] in Varșatantra [12.5 it is said]:

If the moon, having authority in the year, is in the place of Mars, there is secret danger from the king and illnesses. Saturn having authority [in the year and being] in the tenth house is said to make suffering from a blow with iron.

Yādava says [in Tājikayogasudhānidhi 12.82] that in this configuration, the moon should be understood to occupy the eighth [house]:

If the moon in the revolution of the year occupies the eighth, placed in the sign occupied by Mars in the nativity, there are sufferings [inflicted by] the king.

[Continuing from Varșatantra 12.6:]

If Mars is in the eighth, there is danger from fire or a blow [and] danger from the king. If Mars occupies the tenth house, there is a fall from quadrupeds, suffering, and illness from blood.

Concerning this, Yādava says [in Tājikayogasudhānidhi 12.82-83] that in the first configuration, there is danger from fire and so on if Mars, bereft of authority, occupies the eighth joined to the sun; in the second configuration, there is a fall from a mount if Mars, having authority, occupies the tenth:

If Mars, bereft of authority, occupies the eighth with the sun, there is danger from fire and sufferings [inflicted by] the king; but if Mars, having authority, occupies the tenth house, there will surely be a fall from a mount in [that] revolution of the year.

[And] in the Jirnatājika [it is said]:

Jupiter as ruler of the year, aspected by malefics and occupying the eighth in the year, makes loss of property; Saturn, bereft of strength, aspected by malefics and occupying the seventh from the ascendant of the year, makes slander and quarrels. An itthaśāla between the rulers of the ascendant and the eighth brings danger of death; Jupiter as ruler of the year, aspected by malefics and occupying the second house, brings loss of wealth. 
varșatantre |

patite jñe krūradrśāretthaśāle mrtim vadet |

kujahaddāsthite nāśaḥ saumyadrșțe śubham vadet \|

patite krūrākrānte | tathā budhe bhaumahaddāsthite nāśo 'śvādidravyasyety arthaḥ | yādavenāștamasthasya budhasyādhikārahīnasya bhaumetthaśālayutasya phalam uktam |

jñe tv adhikārahīne 'ṣțasthe mrtiḥ syāt kujamūthaśīle \|

lagnādhipe nașțadagdhe yoșidvādo 'śubhānvite |

dagdhādilakṣaṇaṃ vāmanenoktam |

krūraị krūradṛ́á drșțo yukto vārkagrhāntigaḥ|

sa vinașto graho jñeyo dagdhạ pị̂ita ucyate \|

atra yādavena janmalagnavarṣalagneśayoḥ saptamagayoḥ sūryasahitayoḥ phalam uktam |

janmāñgādhipatau samātanupatau vā varșalagnāstage

sārke duștahate striyā saha tadā vādārtiduḥkhāni ca \|

2 dṛ́āāetthaśāle] dṛsāām itthaśāle M 3 dṛștẹ] dṛsṭyā G 4 nāśo 'śvādi] nāśau svādi B; nāśau svadi N 7 'ștasthe] scripsi; șțamasthe B N G K T M 8 nașța] na dṛșța B N || 'śubhānvite] śubhānvitaṃ K T M 10 dṛsāa ] om. B || gṛhāntigaḥ] gṛhāṃgitạ̣ N 11 sa vinașțo] sabirnașțo N || ucyate] eva ca G 15 tadā] ta $G$

2-3 patite ... vadet] VT $12.8 \quad 7$ jñe ... mūthaśíle] TYS $12.83 \quad 8$ lagnādhipe ... 'śubhānvite] VT $12.9 \quad 14-15$ janmā- ... ca] TYS 12.91

7 jñe] The metrical irregularity is due to the omission of the phrase lohäd bhayam, which belongs syntactically with the preceding half-stanza. \| 'ștasthe] The emendation, required by the metre, is supported by MSs TYS1, TYS 3 . 
[And] in Varșatantra [12.8 it is said]:

If Mercury is corrupt and has an itthaśäla with Mars by evil aspect, one should predict death. If it occupies the hadda of Mars, there is loss; [but] if it is aspected by benefics, one should predict good things.

'Corrupt' [means] beset by malefics. That is, with Mercury being thus and occupying the haddā of Mars, there is loss of property such as horses. Yādava [in Täjikayogasudhānidhi 12.83] describes the result of Mercury occupying the eighth house bereft of authority and joined in an itthaśāla with Mars:

But if Mercury bereft of authority occupies the eighth in a mutthaśila with Mars, death will occur.

[Continuing from Varșatantra 12.9:]

If the ruler of the ascendant is corrupt or burnt, joined to malefics, there are disputes with women.

The definition of being burnt and so on is stated by Vāmana:

Being aspected by malefics with an evil aspect or joined [to them while] being placed near the house of the sun, the planet should be known to be corrupt; it is [also] called burnt or afflicted. ${ }^{114}$

Concerning this, Yādava [in Tājikayogasudhānidhi 12.91] describes the result of the rulers of the ascendant of the nativity and the ascendant of the year occupying the seventh accompanied by the sun:

If the ruler of the ascendant of the nativity or the ruler of the ascendant of the year occupies the seventh house from the ascendant of the year with the sun, afflicted by malefics, then there are disputes with a woman, pain and suffering.

[Continuing from Varșatantra 12.9-10:]

114 Cf. the similar definitions quoted from Vāmana himself in the foregoing section (see footnote 94) and from Caṇ̣eśvara in section 1.5. 
janmany aștamago jīvo nādhikārī kalih pṛthuh \| jayah śukrekșaṇād uktah pratyuttaravaśena ca|

tādṛśe gurau śukravīkṣite strīvāde pratyuttaravaśena jayo bhavatīty arthạ̣ | bhaume 'ntyage dhane sūrye vādāt kleśam vinirdiśet $\|$ atra yādavena yogadvayam uktam |

bhaume varșatanor vyaye sati tathā vādavyathātho ravau dravyasthe ripugotravāda udito duștekșanenotkațah $\|$ ripugotrakalir bhittị saṃkhye kujahate 'bdape | dagdho janmāngapo varșe șașthe rogakali diśet \| sūtyabdayor adhikrto bhaumasthāne gurur hatah | pāpair vādah sphuto 'py evam tādráíndau śaneh pade \|

sūtyabdayor bhaumasthāne gurur varșe 'dhikārī pāpair hatas tadā prakaṭo vādah | atha candraḥ sūtyabdayoḥ śanisthāne sthitaḥ varṣe 'dhikārī pāpair hatas tadāpi sphuțavādaḥ syād ity arthah |

\footnotetext{
1 nādhikārī] nādhikāro K T M 4 dhane] om. B N 5 atra] atha M 6 tanor] tanaur N; patau G \| tathā] tadā K T; sadā M \| vādavyathātho] vādonyathātho $M \quad 7$ udito] gadito $G$ 8 saṃkhye] saṃsthe G 9 șașţhe] șțamo G K T M 11 'py evaṃ] śeșaṃ M \|t tādṛsīindau] tādṛsíịndo B N; tādṛ́semạndau M 12 sūtyabdayor] sūtyoṃtyabdayor N 14 tadāpi] sphuṭa add. G

1-2 janmany ... ca] VT 12.9-10 4 bhaume ... vinirdiśet] VT 12.10 6-7 bhaume ... -kațaḥ] TYS 12.92 8-11 ripu ... pade] VT 12.11-12
} 
[If] Jupiter in the nativity occupies the eighth, not having authority, there is a great conflict; and by Venus aspecting, victory is declared on account of a rejoinder.

That is, with Jupiter being such and aspected by Venus, there is victory on account of a rejoinder in the conflict with a woman. [Continuing from Varșatantra 12.10:]

If Mars occupies the twelfth house and the sun is in the second house, one should predict suffering from the dispute.

[But] concerning this, Yādava describes two configurations [in Tãjikayogasudhānidhi 12.92]:

If Mars is in the twelfth house from the ascendant of the year, ${ }^{115}$ there is likewise agitation from a dispute; and if the sun occupies the second house, a dispute with an inimical clan is declared [to result], exacerbated by an evil aspect.

[Continuing from Varșatantra 12.11-12:]

If the ruler of the year is afflicted by Mars, there is conflict with an inimical clan and danger in battle. [If] the ruler of the ascendant of the nativity is burnt in the sixth [house] of the year, one should predict disease and conflict. [If] Jupiter, having authority in the nativity and the year, is afflicted in the place of Mars, ${ }^{116}$ there is a public dispute with evil men; likewise if the moon, being such, is in the place of Saturn.

That is, with Jupiter [residing] in the place of Mars in the nativity and in the year [and] having authority in the year, afflicted by malefics: then there is a publicized dispute. And [if] the moon, [residing] in the place of Saturn in the nativity and the year [and] having authority in the year, is afflicted by malefics, then too there will be a public dispute. [Continuing from Varșatantra 12.13-16:]

115 Text witness G reads: 'If Mars is in the twelfth house as ruler of the year'.

116 Or, as Balabhadra understands the phrase: 'If Jupiter, having authority, is afflicted in the place of Mars in the nativity and the year'. 
sūtyabdayor adhikrte candre budhapade hate |

krūrair videśagamanam vādah syād vimanaskatā $\|$

meșe simhe dhanușy āre 'bdape randhre 'sito bhayam |

mrtau mrtiśalagneśau mrrtyudau pāpadrgyutau \|

yatrarkșe janmani kujạ̣ so 'bdalagnopago yadā |

budho varșapatir naștabalas tatra na śobhanam \|

sārke śanau bhaumayute khāșțasthe vāhanād bhayam |

sārke bhaume 'ștamasthe tu patanam vāhanād bhavet \|

vāmanah |

varșeśvare kujayute randhrasthe maraṇād bhayam |

udite mrtisadmeśe 'stamgate jivasadmape \|

punyasadmeśvarah punyasadmano 'ștamago yadi |

mrtyukrt punyasahame tathā janmāștameśvarah \|

rāśir janmāșțamo mukhyasadmani sveśayuk tathā|

varșāștamarkṣam punyasthaṃ sveśayuktaṃ mrtipradam ||

krūrākrāntam puṇasadma yadi janmāșțameśvarah |

șașthe 'ștame dvādaśe vā tadā mrtyur asamíayah $\|$

munthaheśo 'bdapo vāpi krūrākrānto 'rimrtyugaḥ|

janmalagnāșțamādhisso 'ntyago mrtyum vinirdiśet ||

mukhyasadmani lagne vā candrah krūras tu saptamah |

mrtyukrd yadi vā krürau dhanavyayakrtasthitī||

mṛtișașthagataś candraḥ krūradrșto mrtipradaḥ|

janmalagnābdalagneśau nidhane nidhanapradau ||

2 vimanaskatā] vimanaskṛtā B 3 dhanuṣy āre] dhanuṣpāde K T M 5 'bda] bde K T M 7 bhaumayute] om. B N 8 sārke ... bhavet] om. B N 11 jivasadmape] jivam abdape G 12 punya ${ }^{1}$ ] punye $\mathrm{G} \|$ sadmano] sadmago $\mathrm{B} N \quad 14$ rāśir] śaśi $\mathrm{B} N$; rāśi T M $\|$ mukhya] mukhyaṃ M \| sveśa] kheśa T \| -yuk tathā] yuktayā B N $\quad 15$ sveśa] kheśa T 18 mṛtyugaḥ] mṛtyudaḥ G 19 lagnāșțamā-] janmāșțamā- B N 20 mukhya] sukha B N; punya K T M 21 krūrau] krūro B N \| sthitī] sthitiḥ B N 22 candraḥ] scripsi; candro B N G K T; cando M || krūra] krūre B N a.c. 23 lagnābda] scripsi; lagnāșța B N G K T M || pradau] prado $\mathrm{M}$

1-8 sūty ... bhavet] VT 12.13-16 
If the moon, having authority in the nativity and the year, is afflicted by malefics in the place of Mercury, there will be travel abroad, disputes and distress. If Mars as ruler of the year is in the eighth house in Aries, Leo or Sagittarius, there is danger from swords. The ruler of the eighth house and the ruler of the ascendant [placed] in the eighth house, joined to the aspects of malefics, bring death. When the sign in which Mars was [placed] in the nativity occupies the ascendant of the year, [and] Mercury as ruler of the year has lost its strength, there is no good in that [year]. If Saturn with the sun, and joined to Mars, occupies the tenth or eighth house, there is danger from a mount; but if Mars with the sun occupies the eighth, there will be a fall from a mount. ${ }^{117}$

[And] Vāmana [says]:

If the ruler of the year, joined to Mars, occupies the eighth house, there is danger of death. If the ruler of the lot of death is [heliacally] risen, and the ruler of the lot of life is [heliacally] set, [and] if the ruler of the lot of fortune occupies the eighth from the lot of fortune, it causes death; likewise if the ruler of the eighth [house] in the nativity is on the sahama of fortune. Likewise, the eighth sign [from the ascendant] in the nativity [being placed] on the foremost lot, ${ }^{118}$ joined by its own ruler. The eighth sign [from the ascendant] in the year placed on [the lot of] fortune, joined by its own ruler, brings death. If the lot of fortune is beset by malefics [and] the ruler of the eighth in the nativity is [placed] in the sixth, eighth or twelfth, then without doubt there is death.

[If] the ruler of the munthaha $\bar{a}$ or the ruler of the year, beset by malefics, occupies the sixth or eighth house, [and] the ruler of the eighth from the ascendant in the nativity occupies the twelfth house, one should predict death. [If] the moon is [placed] on the foremost lot or in the ascendant, and a malefic is [in] the seventh, it causes death; or if two malefics have taken up position in the second and twelfth houses. The moon occupying the eighth or sixth house, aspected by malefics, brings death; the rulers of the ascendant in the nativity and the ascendant in the year [placed] in the eighth house [also] bring death.

117 Vāhana 'mount' may also mean 'vehicle'.

118 The lot of fortune. 
samarasiṃhạ |

bhūmisthalagnanāthadyunasthaśaśimuthaśile bhaven mṛtyuḥ| randhrapatilagnapatyos tathetthaśāle ca pāpadrśā $\|$ nidhaneśe kendrasthe lagnapatau nidhanage bhaven mrtyuh | lagnasthe randhrapatau lagnapaśaśinor vināse ca \|

varșatantre |

sakrūre janmape mrtyau mṛtiś ced inthihārkiyuk |

bhaumakșutekșaṇe tatra mrịth syād ātmaghātatah \|

sūtirandhrapatir mando 'ștame 'bde lagnapena cet |

itthaśāli krūradrśā tatkālaṃ mrtyudāyakah \|

mando 'ștame mrtisisetthaśālān mrtyukaraḥ smrtaḥ|

śubhetthaśālāt sarve 'pi yogā nāśubhadāyakāḥ ||

mṛtyukartāro grahāḥ śubhagrahair itthaśālād arișțaṃ parihṛtya pariṇāme śarīrārogyadāḥ syuh | viśeșam āha tejaḥsiṃhah |

svoccādigo balayuto mrtigehanāthaḥ

krūrāhato 'rkarahito gṛhadrgyuto vā |

lagnam tadīsam api vāyadi vīkṣate ruk-

kleśādinut khalu bhaved abale 'nyathātvam \|

lagneśamūsariphato 'bdapatis tu bhavyo

bhaumo 'bdapo gurudrśáapy abalo na nindyaḥ|

1-5 samarasiṃhah ... ca] om. B N K T M 2 dyuna] scripsi; dyūna G || śaśi] scripsi; rāśi G 9 'șțame] șțamo B N G || 'bde] bda G \|| lagnapena cet] lagnape bhavet B N 10 tatkālaṃ] tatkāle K T M 11-12 mando ... dāyakāḥ] om. B N 11 -śālān] -śālī K T M 12 yogā nāśubha] yogānāṃ śubha G T 13 kartāro] kartā roga G p.c. \| parihṛtya] parihṛt B 16 g̣̣ha] graha B N 17 vīkṣate] vīkșite B N K M; vīkṣyite T 18 nut] tat M \| bhaved abale] bhavele N 19 bhavyo] bhavage $\mathrm{K}$

7-8 sakrūre ... ghātatah]] VT 12.21 9-10 sūti ... dāyakah] VT 12.23 11-12 mando ... dāyakāḥ] VT 12.22 15-18 svoccādigo ... 'nyathātvam] DA 24.10 19-682.2 lagneśa ... -śālī] DA 24.13 
[And] Samarasiṃha [says in the Täjikaśāstra]:

If there is a mutthasila between the ruler of the ascendant occupying the fourth house and the moon occupying the seventh house, death will occur; likewise if there is an itthaśäla by evil aspect between the ruler of the eighth house and the ruler of the ascendant. If the ruler of the eighth house occupies an angle and the ruler of the ascendant occupies the eighth house, death will occur, and [likewise] if the ruler of the eighth house occupies the ascendant while the ruler of the ascendant and the moon are [placed] in the eighth house.

[And] in Varșatantra [12.21, 23, 22, it is said]:

If the ruler of the nativity is with a malefic in the eighth house, death occurs if the inthiha is joined by Saturn. If there is a kșuta aspect of Mars on that [place], there will be death by suicide.

If Saturn as ruler of the eighth house in the nativity is [placed] in the eighth in the year, having an itthaśăla by evil aspect with the ruler of the ascendant, it brings about death at that time.

Saturn in the eighth is said to cause death by an itthaśa la with the ruler of the eighth house; [but] by itthaśála with benefics, no configurations give evil [results].

By itthaśála with benefic planets, the planets [potentially] causing death remove the misfortune and eventually give a healthy body. Tejahsimpha states a special rule [in Daivajñālaṃkrti 24.10, 13]:

If the ruler of the eighth house, occupying its exaltation and so on, endowed with strength, unafflicted by malefics, free of the sun, and aspecting or joining [its own] house, aspects the ascendant or its ruler, it surely dispels illness and suffering; [but] if it is weak, the opposite.

By a müsarihpha with the ruler of the ascendant, the ruler of the year becomes good: Mars as ruler of the year with an aspect of Jupiter, even [if] weak, is not to be censured [...] ${ }^{119}$ and captivity. The ruler of the

119 While the text witnesses largely agree on the phrasing of this stanza, its former and latter halves do not connect syntactically, giving the impression that something has been left out. The content of the former half itself does seem rather strange, although I have attempted as sympathetic a translation as possible, and I have been unable to locate it in available independent witnesses of the Daivajñälam krti, where the stanza in question reads quite differently. 
bandhạ̣ ca mrtyupatir āyapatītthaśāli

bhavyo 'ștame na malino malinetthaśälī

malinaḥ pāpagrahaḥ | yādavaḥ |

abdape 'vanisutākșisaṃyute yuddhabhïr bhavati munthaheśvare |

munthahābhavanato 'ștamasthite syān mṛtị śaradi dehadhārinām \|

janmāñgajanmāștapatī ca varșe munthāgatau mrtyukarau pradișțau|

janmāșțape 'bde mrtige ca mrtyur mandāạhyamunthā mrtidārayugdṛk\|

janmāștameśe 'bdaripuryayāșțasthite mrtiḥ syād atha varșakāle |

janmāñgavarșāngapatī mrtisthau tadā bhavetām mṛtidau narānām |

pāpe 'ștame pāpakrtetthaśále mrtyur bhaved varșaniveśakāle \|

yadbhe janau bhümisuto 'bdatatsthe jīve khalārte 'tha kuje gurau vā |

samādhikāre hy anujair vivādo mandānvite śittarucau ca tadvat \|

yadrāśigo janmani somajanmā tadrāśigo 'bde janane balișthe |

candre vivādo nikhilair niruktas tair vaimanasyam paradeśayānam ||

athāșțamabhāvasthitānāṃ sūryādīnāṃ phalāni padmakośe |

ravau cāșțame pịdanaṃ bandhukaștam

saduḥkhakșayopadravau vyādhiśokau |

dhanārtị̣ kalatrāngapị̄̂a sutāder

vrano vātapị

nidhanagataśaśānkah kaștavantam karoti

jvaravamanavikāram codare guptapị̣̂ām |

bhavati kaphavikāro netrarogāngabhañgo

1 -śāīi] -śālo K T M 2 bhavyo 'șțame na] bhavyāṣțamena M \| malino malinetthaśālī] malinena yadītthaśālī G 3 malinaḥ pāpagrahaḥ] om. K T M 5 munthahā] muṃthahī G \| 'șțama] șțame M 7 mandāḍhya] mandādya T M 11 bhūmisuto] bhūmisute K T M \| tatsthe] tasthe B || khalārte] khalāọhye K T M 13 tadrāśigo] tadrāśige K T M 14 vivādo] vivāde N || niruktas] niruktaṃ K T M 17 śokau] kośau B N 20 gata] gataḥ B N \|| śaśānkaḥ kașta] śakah śāṃkeștạ N 22 rogānga] gāṃga T

4-10 abdape ... kāle] TYS 12.86-89 11-14 yadbhe ... yānam] TYS 12.93-94 16-19 ravau ... madhye] TPK $1.8 \quad$ 20-684.1 nidhana ... madhye] TPK 2.8 
eighth house having an itthaśāla with the ruler of the eleventh house is good, [if] not tarnished [or] having an itthaśäla with one that is tarnished.

'Tarnished' means a malefic planet. [And] Yādava [says in Tãjikayogasudhānidhi 12.86-89, 93-94]:

If the ruler of the year is joined to the aspect of Mars, there is danger from battle; if the ruler of the munthaha occupies the eighth from the house of the munthahā, embodied beings meet with death in [that] year. The rulers of the ascendant of the nativity and the eighth of the nativity placed on the munthaha $\bar{a}$ in the year are declared to cause death. If the ruler of the eighth of the nativity occupies the eighth house, there is death; the munthaha a together with Saturn, joined to or aspected by Mars, brings death. If the ruler of the eighth in the nativity occupies the sixth, twelfth or eighth house in the year, death will occur in the course of the year. The rulers of the ascendant of the nativity and the ascendant of the year occupying the eighth house will then bring death to men. If a malefic in the eighth has formed an itthaśäla with [another] malefic, death will occur at the time of [that] revolution of the year.

If Jupiter in the year occupies the sign where Mars was in the nativity and is afflicted by malefics, or if Mars or Jupiter has authority in the year, there is dispute with siblings; likewise if the moon is joined by Saturn. If the moon, being powerful in the nativity, occupies that sign in the year where Mercury was in the nativity, disputes with everyone is declared [to be the result; likewise] dejection due to them and travel to other lands.

Next, the results of the sun and other [planets] occupying the eighth house [are described] in [Tājika]padmakośa $[1.8,2.8,3.8,4.8,5.8,6.8,7.8$, 8.8]:

If the sun is in the eighth, there will be suffering, evils to kinsmen, trouble, loss and misfortune, ailment and sorrow, distress with regard to wealth, bodily pain for the [native's] wife, wounds to children and so on, and suffering from [the humour of] wind, during the year.

The moon occupying the eighth house makes [the native] suffer evils and [makes] disorders of fever and vomiting and hidden pain in the stomach. There are disorders of phlegm, eye disease, broken limbs, 
jalabhayam arivādo dravyanāśo 'bdamadhye \|

kuje cāșțame śatrupị̂āngakaștam

vraṇasyodayaś cāninanānām ca rogaḥ|

dhanānām vināsó bhavec chastraghātas

tathā vyagratā guptacintā narasya \|

niśānāthaputro yadā randhrasamstho

naram mrtyutulyam kaphārtim karoti |

jvarādiprakopo bhaven netrapīda

bhayạ̣ vyagratā hāyane taddaśāyām \|

jvaravamanakaphärtir naidhanasthe surejye

bahulakaținarogah karnayor netrayoś ca|

bhavati bhayam aribhyo yoșito 'ngeșu pị̂a

vranakrtabahupịdā hāyane 'smin narāṇām ||

mrtyusthito mrtyubhayam manuṣyam śukraḥ karotīha janāpavādam |

jvarādipịdām atha bhïtikaștam netre ca rogo ripubhir vivādaḥ $\|$

nidhanago nidhanam kurute śanir jvaravimardakaphārtijanāpadam |

nrpabhayam dhanahānim arer bhayam bhavati tāpakarah pavanodayah $\|$

chidrasthito mrtyusamam manusyam rāhus tathä bhüpabhayam karoti $\mid$

jvarātisāraṃ ca kaphārtidoṣaṃ viṣūcikā vāyubhayam narāṇām ||

maṇitthah |

cakșūrug dhanahānih syād bahupịdā kalevare |

pittajā vișabhūpālavyālapị̣̂ạțtame ravau \| aștamasthe 'lpasaṃtoșo dravyanāśa upadravah |

śleșmacakșurvikāraṃ ca varșādau ca niśākare \|

raktapittaprakopam ca mahāpīdā dhanavyayam |

vipattir iștavargasya așțamasthe dharāsute \|

läbham saukhyam pramodam ca rājapūjām ripukșayam |

vidadhāti nṛnāṃ varșe saumyo mrtyugatạ sadā \|

3 -odayaś] -odayañ M 4 chastra] chatru G 7 tulyaṃ] tyulyam G 10 naidhanasthe] nirdhanasthe $G \quad 12$ yoṣito 'ńgeșu] yoṣidañgeșu G K T M 14 śukrah] śukah G 16 janāpadam] janāpadaḥ K T M 17 hānim arer bhayaṃ] hāni bhaven madhye B a.c. N; hānibhaye mṛdhe G; hānibhayam mṛdhe K T M 22 ravau] gurau G 24 vikāraṃ] vikāre B N; vikāraś M \| niśākare] niśādhipe $\mathrm{G} \quad 25$ prakopaṃ] prakope N; prakopaś M \| pị̄̂ā] pị̣̄āṃ B N; pījāṃ G; pị̄̂ān K T || vyayam] vyayaḥ K T M

2-5 kuje ... narasya] TPK 3.8 6-9 niśā ... daśāyām] TPK $4.8 \quad 10-13$ jvara ... narāṇām] TPK 5.8 14-15 mṛtyu ... vivādah] TPK $6.8 \quad$ 16-17 nidhanago ... -odayah] TPK $7.8 \quad 18-19$ chidra ... narānām] TPK 8.8 
danger from water, disputes with enemies, and loss of property during the year.

If Mars is in the eighth, there is suffering from enemies and evils of the body; wounds appear, and there is illness to [the native's] womenfolk; the man will suffer loss of wealth, blows from a weapon, agitation and secret anxiety.

When Mercury occupies the eighth house, it makes suffering from phlegm equal to death for a man; there will be disorders like fever, suffering from the eyes, fear and agitation during its period in the year.

If Jupiter occupies the eighth house, there is suffering from fever, vomiting, and phlegm, profuse and severe illness of the ears and eyes, danger from enemies, pain of the limbs for the [native's] wife, and much suffering caused by wounds to men in this year.

Occupying the eighth house, Venus makes a man fear death, [causes] slander by [common] people, suffering from fever and so on; there is the evil of fear, illness of the eyes, and disputes with enemies.

Occupying the eighth house, Saturn causes death, feverish disorders, suffering from phlegm, and misfortunes from [common] people, danger from the king, loss of wealth and danger from enemies; [the humour of] wind arises to torment [the native].

Occupying the eighth house, Rāhu makes a man resemble death, and likewise [makes] danger for men from the king, dysentery with fever and suffering from a disorder of phlegm, and danger from cholera and [the humour of] wind.

[And] Manittha [says]:

There will be eye disease, loss of wealth, much bodily suffering produced by bile, and suffering from poison, kings, and snakes, if the sun is in the eighth.

If the moon occupies the eighth at the beginning of the year, there is little contentment, loss of property, misfortune, and disorders of phlegm and of the eyes.

There is agitation of blood and bile, great suffering, loss of wealth, and adversities for loved ones, if Mars occupies the eighth.

Mercury occupying the eighth house always bestows gain, happiness and delight, honour from the king and the destruction of enemies on men in [that] year. 
dhanavyayam anārogyaṃ kalaham mitravargataḥ|

viyogam ca pravāsam ca aștame devapüjite \|

alpaläbham anārogyam jāyāputrādipịdanam |

dharmanāśam pravāsaṃ ca bhṛuputre 'ștamasthite \|

rogapị̀ā mahāryādhịh putrajāyādipịdanam |

vyasanam dravyahāniś ca hāyane 'ștamage śanau \|

dhanavyayas tv anārogyam vivādo bandhubhị saha |

strīkaștam ca pravāsaś ca rāhur aștamago yadi $\|$

ity așțamabhāvavicāraḥ ||

atha navamabhāvavicārah | tatra navamabhāve kị̣ cintanīyam ity uktaṃ 10 caṇ̣eśvareṇa |

svādhyāyadīkṣāsuragehayātrā

cakrasya ceștā mațadharmakrtyam |

guros tu kāryādy abhișecanam ca

jalāśrayaḥ śālakadevarādīn |

bhrātur bhaginyāh śvaśurasya cintā

punyam ca punye kathitam mahadbhih $\|$

1-3 kalaham ... anārogyaṃ] om. B N $\quad 2$ așțame devapūjite] jāyāputrādipịḍanam K T M $\quad 5$ pị̄ā mahā] pị̣̄ādijā $\mathrm{G} \quad 9$ bhāvavicāraḥ] bhāvaḥ $\mathrm{G} \quad 13$ mațha] bhava $\mathrm{G} \quad 16$ bhrātur] dhātur B N

120 Svādhyāya, originally the private recitation of the Veda, but later extended to include the study of any text (particularly religious texts) and/or the recitation of non-Vedic mantras.

$121 D i ̄ k s ̦ a$, , consecration or initiation into a religious practice, typically performed by a preceptor ( guru/ācārya) and not always clearly distinguishable from abhișeka/abhișecana (below).

122 This may refer simply to travel by carriage, but could also allude to religious practices (cf. Bhagavadgìtā 3.16 for use of this originally Buddhist imagery) or even to the wielding of royal authority. 
There is loss of wealth, poor health, quarrels with friends, separation and living abroad, if Jupiter is in the eighth.

There is little gain, poor health, suffering to wife, children and so on, loss of merit, and living abroad, if Venus occupies the eighth.

There is suffering from disease, severe illness, suffering to children, wife and so on, vice and loss of property, if Saturn occupies the eighth in the year.

There is loss of wealth, poor health, disputes with kinsmen, evils to [the native's] wife, and living abroad, if Rāhu occupies the eighth.

This concludes the judgement of the eighth house.

\subsection{The Ninth House}

Next, the judgement of the ninth house. Concerning that, Candeśvara describes what is to be considered from the ninth house:

Readings, ${ }^{120}$ initiation, ${ }^{121}$ temples, journeys, the motion of the wheel, ${ }^{122}$ monasteries, ${ }^{123}$ religious functions, a preceptor's duties and consecration, ${ }^{124}$ ponds, ${ }^{125}$ enclosures, ${ }^{126}$ the husband's brother and so on, ${ }^{127}$ considerations of the brother, sister, and father-in-law, and piety are assigned to the ninth house by the great [sages].

123 Mața, a Brahmanic institution typically housing a senior preceptor and sometimes a number of other monastics, and functioning as a centre for religious instruction and scholarship.

124 Abhișecana, 'anointing' or, more literally, sprinkling or pouring of water or other liquids over a sacred image or a person - in the latter case performed as an act of conferring religious or royal authority.

125 Or, possibly, '[creatures] resorting to water'.

126 Or 'hall', etc. The context of this term is not clear.

127 Possibly brothers-in-law in general, as an instance of turned or derived houses (the ninth from the ascendant being the third house of siblings reckoned from the seventh house of the spouse), although typically, devara specifically denotes the brother of a woman's husband. This compound appears in the accusative in all text witnesses, despite the lack of any verb to go with it and the fact that the previous significations are all given in the nominative. It thus seems possible that half a stanza, containing the missing verb, has been omitted. 
atrāpi vicāraḥ pūrvavat | atha yogāḥ | varṣatantre |

bhaume 'bdape trinavage krūrāyukte balānvite | guṇāvahas tadā mārgaś caram kāryam sthiram tatah \| tridharmastho 'bdapah sūryaḥ kambülì märgasaukhyadaḥ| anyapreșaṇayānam syāt sa cen nādhikrto bhavet \|

varṣeśaḥ sūryas trinavamagaḥ svag̣̣hoccādigaḥ kambūlī candretthaśālavān mārgasaukhyaprado bhavati | etādṛśo 'rko 'dhikārarahitạ anyapreșaṇayānapradaḥ | atrādhikāraḥ svagṛhādiko jñeyaḥ | samarasiṃhạ̣ |

mama gamanam bhavitā kila na veti lagneśvare 'tha candre vā | navameśamuthaśile sati navamasthe vā bhaved gamanam \| lagnasthe navamapatau lagnādhipamuthaśile ca saṃcārāt | rahite 'pi yāti na punar navamadrśá varjite yoge \| lagnapatau kendrasthe sahajagrahamuthaśile ca vikrūre | gamanam syād asmin vā candre kendrasthamuthaśile na gatịn \| nrpayātrāprcchāyām dhanasthite niradhikāriṇi krūre| prșțhagatānām aśubhaṃ bhaume 'gnibhayam sajhakațakam samaram \| mande caurajalabhayam makabūlakrūrato na bhayam |

\footnotetext{
2 bhaume 'bdape] bhaumodaye M 3 sthiram tatah] sthitaṃtah N 4 'bdapah] bdah \| kambūili] kambūlo K T M $\quad 5$ anya] anye T $\quad 6$ navamagah] navagaḥ K T M $\quad 7$ saukhya om. K T M 8 pradaḥ] daḥ K M \| atrādhikāraḥ] adhikāraḥ B N K T M \| samarasiṃhạ̣] samarasiṃhavākyaṃ K T; samarasiṃhavākyam M 8-69o.6 samarasiṃhah ... varṣatantre] om. BN 9 kila] om. KTM \| 'tha] bda KTM 12 rahite] scripsi; rahito G KTM \| varjite] varjate G 13 sahajagraha] sahajagaś ca K T M 14 candre] vā add. K T M \| kendrastha] kendrasya K T M $\quad 15$ nụpa] nụpā K \| pṛcchāyāṃ] șțaddāyāṃ G 16 sajhakaṭakaṃ] sasajhațakaṃ M 17 mande] ca add. K T || bhayaṃ] bhaya G K T || makabūla] kaṃbūla M

2-5 bhaume ... bhavet] VT 13.1-2

8 jñeyaḥ] At this point K T M add: mamādireșāmparyaṃtam samarasị̣havākyaṃ na sarvapustakeșu, where mamādireșām - ought properly to read mamādìtareșāmm-. It is not entirely clear whether this is an intrusive gloss referring to MSs of the HR, or a comment by Balabhadra referring to MSS of the TŚ; but as B N do in fact omit the Samarasiṃha passage reading mama [...] itareșām, the former alternative seems more likely, indicating that the scribe of a hyparchetype shared by K T M was working from multiple Mss.
} 
Here, too, judgement is [to be made] as before. Now, configurations; [and] in Varșatantra [13.1-2 it is said]:

If Mars as ruler of the year occupies the third or ninth, not joined by malefics [but] endowed with strength, then there is a profitable journey, changing affairs [and] then stable ones. ${ }^{128}$ The sun occupying the third or ninth house as ruler of the year, being in kambüla, gives happiness from journeys; there will be travel on commission for another if it should not be in authority.

The sun, ruler of the year, occupying the third or ninth, occupying its domicile, exaltation and so on, being in kambüla, [that is], forming an itthaśâla with the moon, brings about happiness from journeys. Such a sun bereft of authority brings about travel on commission for another. Here, 'authority' should be understood as domicile and so on. [And] Samarasimha [says in the Tājikaśāstra]:129

'Will I make a journey or not?' If [a client asks thus and] the ruler of the ascendant or the moon has a mutthaśila with the ruler of the ninth or occupies the ninth, there will be a journey. If the ruler of the ninth occupies the ascendant and has a mutthaśila with the ruler of the ascendant, [or] even if it is bereft [of a mutthaśila] due to a transfer, he goes [on a journey], but not if the configuration lacks an aspect [on] the ninth. ${ }^{130}$ If the ruler of the ascendant occupies an angle in a mutthaśila with a planet [in] the third house, free from malefics, there will be a journey; [but] if it or the moon has a mutthaśila with [a planet] occupying an angle, there is no journey.

In a question about a king's journey, if a malefic without authority occupies the second house, there is evil for those left behind: if it is Mars, there is danger from fire, fighting and quarrels; if Saturn, danger from robbers and water. From a malefic with makabüla there is no

128 The meaning of the last phrases is uncertain; the terms used are the same as for 'movable' and 'fixed' signs. Viśvanātha ad VT 13.1 says: 'Although affairs are changing (cara), [that is], quickly accomplished, then, [that is], after that, affairs are stable (sthira), [that is], slowly accomplished.'

129 The following quotation is omitted by text witnesses B N, while K T M include the comment that the quotation 'is not found in all books'.

130 This somewhat cryptic sentence represents a condensed version of a paragraph taken from Sahl ibn Bishr's K. fil-masä’il, for a translation of which see Dykes 2019a: $148 \mathrm{f}$. The 'transfer' (saṃcāra) refers to a third planet disrupting the configuration, 'leading away' the light of the applying planet. 
dhananāthe nīcasthe cāstamite śobhanam na punaḥ \| lagnapaśaśinoh krūrārditayor vyākulyam išacitte 'rtị̣| sa krūro yadi lagnākāsāantaragas tadā nivartanataḥ \| ākāśāstāntarage 'smin mārgād astaturyamadhyasthe | anucarajanasya turyavilagnāntahsthe na bhadram itareșām ||

varṣatantre |

muthahāyā dyūnasaṃsthah svagṛhoccagataḥ śaśi $\mid$ videśagamanaṃ kuryāt kleśạ pāpekșaṇād bhavet \|

vāmanah |

śukre 'bdape trinavage pathi saukhyam prajāyate | tasminn astamgate vakre krürayukte gamo 'subhạ || budhe 'bdape tridharmasthe devayātrām samādiśet | gurau trinavage 'bdeśe nṛ̣ạ̄n śubhagamo bhavet \| yoge dharmeśalagneśoś cintitam gamanam bhavet | guror navamage bhaume nṛnạ̣̄ śubhagamo bhavet ||

hillājạ̣|

yatra janmani mandạ̣ syāt sa rāśir navame 'bdataḥ| janmādhikārījñah krūrayuto 'trajhakațādhvadaḥ\| janmādhikāriṇi budhe kujāspadagate sati |

2 krūrārditayor] krūrārditayo G 3 yadi] scripsi; om. G K T M || lagnākāśā-] scripsi; lagnakāśā- G; lagnakośāa K T M \| tadā nivartanataḥ] tadāptikṛd gaṇatạ̣ K T M 4 ākāsaāstā-] ākāśá- K T M \|| mārgād asta] mārgadas tat M $\quad 6$ varșatantre] om. K T M 7 muthahāyā] muthahāto $\mathrm{G} \quad 12$ 'bdape] bdempe N 14 yoge] yome K M $\quad$ 14-15 yoge ... bhavet] om. B N 14 lagneśoś] lagneśaś $\mathrm{G} 15$ guror] gurau $\mathrm{G} \|$ śubhagamo bhavet] śubhavet $\mathrm{G}$ a.c.; śubhagamovet $\mathrm{G}$ p.c. $\quad 16$ hillājạ̣] hillāje B N 18 jñah] om. G || 'tra] jñah M \| jhakațā-] śakațā- M 19-692.1 janmā- ... budhaiḥ] om. G

7-8 muthahāyā ... bhavet] VT 11.13 
danger. ${ }^{131}$ Again, if the ruler of the second house occupies its fall or is [heliacally] set, it is not good. If the ruler of the ascendant and the moon are afflicted by a malefic, there is agitation and suffering to the ruler's mind. If that malefic is placed between the ascendant and the tenth house, then [the suffering] is due to turning back; ${ }^{132}$ if it is placed between the tenth and the seventh house, due to the journey; if it is placed between the seventh house and the fourth, there is misfortune for his retinue; if it is placed between the fourth and the ascendant, for the others.

[And] in Varșatantra [11.13 it is said]:

The moon placed in the seventh house from the munthahā, occupying its domicile or exaltation, will make a journey abroad. By malefics aspecting, there will be suffering.

[And] Vāmana [says]:

If Venus as ruler of the year occupies the third or ninth, happiness on a journey results; [but] if it is [heliacally] set, retrograde, [or] joined to malefics, the journey is unfortunate. If Mercury as ruler of the year occupies the third or ninth house, one should predict a pilgrimage; if Jupiter as ruler of the year occupies the third or ninth, men will make a fortunate journey. If there is a configuration between the ruler of the ninth house and the ruler of the ascendant, there will be a planned journey; if Mars occupies the ninth from Jupiter, men will make a fortunate journey.

[And] Hillāja [says]:

[If] the sign where Saturn was in the nativity should be in the ninth in the year, Mercury, having authority in the nativity and joined to a malefic in this [sign], brings a journey of quarrels; [but] if Mercury, having authority in the nativity and occupying the place of Mars, is free

131 Whether understood by Samarasimpha or not, this phrasing reflects the original sense of the Arabic maqbül 'reception', that is, the malefic in question forming an aspect with a planet having dignity (particularly by domicile or exaltation) in the part of the zodiac where the malefic is located. The source is again Sahl; see Dykes 2019a: 153 .

132 Text witnesses K T M read: 'then it makes gain from his troops'. 
pāpayogādirahite suyānam gaditaṃ budhaih $\|$ janmādhikārasahitau jīvendū pāpasamyutau | varșe navamagau mandasthāne dūragamapradau \| janmādhikārī vā bhaumah śanisthāne śubhānvitaḥ| lagnān navamago varșe dūrayātrāpradāyakah || save mārgapatau varșe mārgasadmeśvare gamaḥ| jīvasthāne tridharmasthe kuje tatra śubho gamaḥ| budhasthāne kujo lagnādhišadrștah suyānadah \| save bhaumah svarāsistho varșe navamago bhavet $\mid$ svagṛe saṃsthito yātrām uttamām samprayacchati || varșe 'dhikārarahitah śanir dharme kuyānadaḥ| varșe 'dhikārarahite gurau navamasamsthite | dūrayātrā tatra nrpād dhanamānādilabdhayaḥ $\|$ bhaume 'bdape ca patite svajanād dūrato gamaḥ | navamādhiśakambūlayoge yātrāṃ vinirdiśet \| svagrhoccagataś candro navame yadi samsthitah | muthahāsaptame tatra videśagamanam bhavet \|

hāyanasindhau |

varșeśe sabale mārge varșe yātrā sukhapradā| tasminn astamgate vakre nirbale duhkhado gamah $\|$ gurubhe navamaś candraḥ sabalo 'bde suyānadaḥ| mando 'bdapo 'nadhikrto navamasthah kuyānadah $\|$ gurur evamvidho varșe dūrayātrāpradāyakaḥ| evam trinavago bhaumạ̣ krūradrșțạ̣ kuyānadaḥ \| janmalagnādhipo mārgādhipo vā navamasthitaḥ| trigo vā yānadạ saumyo janmakāle 'nkabhāvagah | sa eva varșe mārgasthạ̣ śubhayātrāpradāyakaḥ \| alpāmśo dharmapạ śighro brhadamśso vilagnapạ̣ | mandagaś cobhayor itthaśäle 'kasmād gamo bhavet \|

6 save] sarve B N T M; sarva K $\|$ patau] gatā B N K T M \| mārga² ] mārge G 7-8 tridharmasthe ... suyānadah]] om. G 9 save] sa cet B N; sarve K T M \| bhaumah] bhaumo G \| svarāśistho] om. G 11 rahitaḥ] rahito $G \quad 15$ yātrāṃ] yotrāṃ N 16 navame] navamo B $\mathrm{N} \quad 18$ hāyanasindhau $]$ om. B N 20 vakre] vaktre $\mathrm{T} \quad 21$ navamaś] navanamaś $\mathrm{T} \quad 23-24$ gurur ... kuyānadah] om. B N T 28 alpāṃśo] svalpāṃśo N G K T M

11 kuyānadah] At this point $\mathrm{G}$ adds a slightly defective version of two half-stanzas omitted above: dharmasthe kuje tatrā 'bdedhikāre śubho gamaḥ| budhasthāne kujo lagnādhiš́adrșțah suyānadah. 
from configurations with the malefics and so on, the wise proclaim a good journey.

Jupiter and the moon, endowed with authority in the nativity [but] joined to malefics and occupying the ninth in the year, in the place of Saturn, bring a distant journey. Or Mars, having authority in the nativity and joined to benefics in the place of Saturn, occupying the ninth from the ascendant in the year, brings about a distant journey.

If the ruler of the ninth house in the nativity rules the lot of journeys in the year, there is travel; if Mars occupies the third or ninth house in the place of Jupiter, there is fortunate travel. Mars in the place of Mercury, aspected by the ruler of the ascendant, gives a good journey. Should Mars occupy its domicile in the nativity and be placed in the ninth in the year, [once more] occupying its domicile, it bestows an excellent journey.

Saturn bereft of authority in the year, [placed] in the ninth house, brings a bad journey. If Jupiter, bereft of authority in the year, occupies the ninth, there is a distant journey, [but] on it, there is gain of wealth, honour and so on from the king. And if Mars as ruler of the year is corrupt, there is a journey far away from one's own people. If the ruler of the ninth has a kambüla configuration, one should predict a journey. If the moon, occupying its domicile or exaltation, is placed in the ninth [from the ascendant and] in the seventh from the munthah $\bar{a}$, then there will be a journey abroad.

[And] in the Hāyanasindhu [it is said]:

If the ruler of the year is strong in the ninth house, a journey that year brings happiness; [but] if it is [heliacally] set, retrograde, [or] weak, travel brings suffering. The moon strong in a sign of Jupiter [in] the ninth in a year gives a good journey; Saturn as ruler of the year occupying the ninth without authority gives a bad journey. Jupiter being such in the year brings about a distant journey; such a Mars occupying the third or ninth, aspected by malefics, gives a bad journey. The ruler of the ascendant of the nativity, or the ruler of the ninth house, occupying the ninth or the third [in the year] gives a journey. A benefic occupying the ninth house at the time of the nativity and itself placed in the ninth house in the year brings about a fortunate journey.

[If] the ruler of the ninth house is swifter with fewer degrees, [while] the ruler of the ascendant is slower with more degrees, if there is an itthaśâla between the two, a sudden journey will take place. [If] the 
svalpāmeśo lagnapaḥ śīghro bahvaṃśo dharmabhāvapaḥ|

antyagaś cobhayor itthaśālaś cintitamārgadạ \|

kendrāyabhāve yogaś cet tadā śreșțaphalam game |

dhane bhümidhanaprāptis turye syuḥ saukhyasampadaḥ|

vyayāsțame 'ricaurād bhịh sakrūre lagnape mrtị̣ \|

varșeśavarșalagneśayogaś cintitamārgadaḥ|

munthālagnapayor yogo varșe syāc cintitādhvadah \|

atra tejaḥsiṃhena varșeśalagneśayor itthaśāle acintitayātrāyoga uktaḥ |

panthāngape muthaśile 'bdabhujā tv acintyah

syāc cintitaś ca viparītagatetthaśāle || iti |

varṣatantre |

varșeśo balavān pāpāyutaḥ kendre 'dhikāravān \|

adhikāragatih saṃkhye senāpatye 'pi vā vadet |

evamvidhe kuje jīvayute 'rkān nirgate punaḥ\|

parasainyoparigatir jayakhyātisukhāvahā|

evaṃvidhe kendravartini balayute 'dhikāravati | krūragraharahite bhaume yoga uktas tejaḥsiṃhena|

kendre 'bdape vimaline sabale ca sādhi-

kāre 'dhikāragatirukkșayavaibhavādyam |

2 antyagaś] alpagaś G K T M $\quad 3-5$ kendrāya ... mṛtiḥ] om. B N K T M $\quad 6-7$ varșeśa ... syāc] varșeśalagneśayor icchaśāle B N $\quad 7$-ādhvadaḥ] -ādhvagaḥ G 8 atra] tatra K T M \| itthaśāle] itthaśāla G 8-10 acintita ... -etthaśāle] om. G 9 panthāngape] paṃthāgame B N; vrithāṃgape K; vṛthāṃgape M \| tv acintyaḥ] viciṃtyas K T M 12 balavān] balaccān N 13 adhikāra] adhikāre G K T M 14 vidhe] budhe B \| kuje] kujī G 15 jaya] scripsi; jayā B N; jāyā G K T M 16 yute] yukte G 17 uktas] uktames N $\quad$ 18-19 kendre ... -ādyam] om. B $\mathrm{N}$

9-10 panthā ... -etthaśāle] DA 25.2 12-15 varṣeśo ... sukhāvahā] VT 13.10-12 18-696.2 kendre ... saukhyam] DA 25.5

18 vimaline] At the top of folio $138^{\mathrm{v}}$, G adds the following stanza without indicating where it should be inserted: varșe lagnāt trikonasthe jñe bhrgau vā valānvite || videśam yāti gehastho videśastho graham vrajet || The same stanza (with grham for the incorrect graham) recurs shortly below in K T M as a quotation from Caṇ̣eśvara. 
ruler of the ascendant is swifter with fewer degrees, [while] the ruler of the ninth house lags behind with more degrees, an itthaśála between the two brings a planned journey. If the configuration takes place in angles or the eleventh house, then the journey gives excellent results; in the second house, there is gain of land and wealth; in the fourth, there will be happiness and riches; in the twelfth or eighth, there is danger from enemies and robbers; if the ruler of the ascendant joins a malefic, death. A configuration between the ruler of the year and the ruler of the ascendant of the year brings a planned journey; a configuration between the rulers of the munthaha $\bar{a}$ and the ascendant in the year will [likewise] bring a planned journey.

Concerning this, Tejaḥsiṃha says [in Daivajñalaṃkrti 25.2] that it is a configuration for an unplanned journey if there is an itthaśäla between the ruler of the year and the ruler of the ascendant:

If the ruler of the ninth house or the ascendant has a mutthasila with the ruler of the year, [the journey] is unplanned, but planned if the itthaśāla is reversed.

[And] in Varșatantra [13.10-12 it is said]:

[If] the ruler of the year is strong, not joined to malefics, in an angle, possessing authority, one should say [that there will be] a position of authority in battle or in the command of an army. Mars being such, and further joined to Jupiter and having come out from under the sun, there is an advance on the opposing army, bringing victory, renown and happiness.

'Being such' [means] occupying an angle, endowed with strength and possessing authority. [In Daivajñălaṃkrti 25.5], Tejahsiṃha describes the configuration with Mars being free from malefic planets:

If the ruler of the year is [placed] in an angle, strong and without any tarnished [planet], in authority, there is a position of authority, disappearance of illness, [attainment of] rank and so forth. Indeed, if 
kendre kuje guruyute khalanirgate 'risainyopari pragatir atra jayādisaukhyam \|

yādavaḥ |

yānādyam vibalabalānusāravedyam

munthāyām aśubhaśubharkṣakhețabhāji ||

svadhvābde kisimapatau janurnaveśe

mārgeśād api sahamāc ca cintyam evam \|

tājikatilake |

jāmitragas tu muthahābhavanāc chaśāinkaḥ svoccādigo 'mbaragato gamanam vidadhyāt | dravyārjanādigamane khalu punyasadmavìryeña tājikavidā sudhiyātha vācyam \|

samarasiṃhạ

navameśamūthaśle lagnādhiśe ca krūraripudrśá drșțe |

gamane 'vasānatah syāt prașțh kārye kșayo 'rthasya \|

krūre 'smin șașthapatau rogo vyayape ca bandhanam jñeyam | sapteśe 'ștapatau vā caurāribhayam ca lagnage maraṇam \| chidrasthe ripudrștyā dhananāśas turyage dhanavināśạ̣|

\footnotetext{
1 khala] khalu B N 2 pragatir atra] gatiratna B N; pragatiratna K T M 4 balānusāra] balānusāri K T M 5 munthāyām] muṃthādyām B N 6 svadhvābde] tv adhvābde N; svotrābdape K T; svoccābde M || kisima] kimasi K \| janur] janu B N || naveśe] navaiśe K 7 mārgeśād] mārgasād B N 10 go 'mbaragato] govaragatom $\mathrm{K}$ T; gocaragato $\mathrm{M} \quad 12$ vidā] vidāṃ M $\quad$ 13-698.7 samarasiṃhaḥ ... kārye] om. B N K T M 15 kārye] scripsi; kārya G 16 vyayape] scripsi; vyayage $G \quad 17$ lagnage] scripsi; lagnape $G \quad 18$ chidrasthe] scripsi; chidrasthāne G

4-5 yānādyaṃ ... bhāji] TYS $12.102 \quad$ 6-7 svadhvābde ... evam] TYS 12.103

14 navameśa ... dṛșțe] This half-stanza comprises 34 morae rather than the 33 noted in some earlier non-standard stanzas. Emending it to end -drgdrște would make it conform to that pattern, with 5 morae in the seventh foot.
} 
Mars is [placed] in an angle, joined to Jupiter and having escaped the malefics, ${ }^{133}$ there is an advance on the enemy army, victory and other happiness in this [year].

[And] Yādava [says in Tājikayogasudhānidhi 12.102, 103]:

Travel and so forth should be understood in accordance with weakness and strength, as the munthahā resorts to malefic or benefic signs and planets.

There is a good journey in the year if the ruler of the kisima rules the ninth [house] in the nativity. The matter should be considered thus from the ruler of the ninth house and from the sahama.

[And] in the Täjikatilaka [it is said]:

Occupying the seventh house from the house of the munthaha , the moon, placed in its exaltation and so on and occupying the tenth house [from the ascendant], brings about a journey. When a journey is made for [the purpose of] earning wealth and so on, the wise knower of the Tajika [science] should pronounce according to the strength of the lot of fortune.

[And] Samarasiṃha [says in the Tãjikaśāstra]:134

If the ruler of the ascendant has a mutthasila with the ruler of the ninth [but] is aspected with an inimical aspect by a malefic, if the querent should make a journey from his residence, his wealth will be lost in the undertaking. If this malefic is ruler of the sixth [house], there is illness, and if ruler of the twelfth, bondage should be understood [to occur]. If it is ruler of the seventh or ruler of the eighth, there is danger from robbers and enemies, and if it occupies the ascendant, death. If it occupies the eighth house [and aspects] with an inimical aspect, there is loss of wealth; occupying the fourth, destruction of wealth.

133 Although this is clearly the reading intended by Balabhadra, nirgata 'come out of, escaped' is more commonly used of a planet separating from the sun and becoming visible; and independent witnesses of the Daivajñälamkrti do in fact read 'the sun' rather than 'the malefics'.

134 This quotation from Samarasimha, like the previous one, is missing from several text witnesses. 
lagneśe navameśvaramuthaśilakrti randhrasaptame kaștam \| udite 'smin pāpān niḥsrte ca śubhasukhakarah panthāh | candramakambūle sati viśeșatas tanupapūrnadṛsi $\|$ lagnān mārgānubhavo vyomnaḥ kāryam smarād gateh sthānam | bhümeh kāryaparinatir lagne śubhasaṃyute śarīrasukham || daśame śubhe ca siddhih kāryasyāste prayāti yatsthāne| tatra śubham ca caturthe parịnāme sundaram kārye \|

atha yātrāyāṃ digjñānam uktaṃ romakeṇa |

agnirāsisir bhavet pūrvā dakșināa prthivī bhavet | vāyurāsith paścimā ca saumyāśā jalabhe smṛtā $\|$

atra yātrāyogakārakānāạm grahānaām madhye yo balavāṃs tadadhișțhitarāśau gamanaṃ vācyam | balasāmye tanmadhye kendrasthagrahādhișțitarāśau gamanaṃ vācyam | tadabhāve 'pi navamarāśidiggamanaṃ vācyam iti viśeșaḥ | caṇḍeśvaraḥ |

varșe lagnāt trikonasthe jñe bhrgau vā balānvite | videśam yāti gehastho videśastho gṛham vrajet || sukhe vyomni sthite saumye gamanam na tadā bhavet | tatraiva gamanam pāpe vakrī khețo yadā na hi $\|$ bhāgyapo lagnago vā syāc candrago vā viśeșatah | candralagneśvarau bhāgye gamas tatrāpy acintitặ $\|$ candro lagnapatir vāpi kendrakhetaih sahāgamaḥ| siddhe 'pi gamane tatra gamanam neti niścitam \| dyūnape dharmage yānam avaśyam nirdiśed budhah | cararāsișu kendreșu śubhayukteșu niścitam | grāmādau gamanaṃ brūyāt pāpayukte cirād bhavet \|

2 sukhakarah] scripsi; sukhākarah G $\quad 5$ parinatir] scripsi; paraṇatir G $\quad 7$ sundaraṃ] scripsi; sundaraḥ G 11 grahāṇāṃ] om. B N G 12 bala] bāla N || grahādhișṭhita] grahā șthita K 15-16 varșe ... vrajet] om. B N G $\quad 21$ kendra] keṃdre B N K T M \| sahāgamaḥ] sahāgrahāḥ B N; sahāgragaḥ K M 
If the ruler of the ascendant makes a mutthasila with the ruler of the ninth in the eighth house or the seventh, there is evil. But if it is [heliacally] risen and freed from the malefic, the journey is fortunate and brings happiness, in particular if there is a makabüla with the moon perfecting an aspect with the ruler of the ascendant.

From the ascendant, the [native's] experience of the journey [is known]; from the tenth house, his affairs; from the seventh house, the place to which he goes; from the fourth house, the outcome of the affairs. If the ascendant is joined by a benefic, there are pleasures of the body; if a benefic is in the tenth, success in affairs; in the seventh, good things in the place to which he travels; in the fourth, an agreeable outcome to the affairs.

Next, Romaka describes the knowledge of the direction of travel:

A fire sign will be the east, earth will be the south, an air sign the west, and the northern quarter is said to be [found] in a water sign.

Concerning this, among the planets forming a configuration for travel, a journey should be predicted in [the direction of] the sign occupied by one that is strong. If their strength is equal, a journey should be predicted in [the direction of] the sign occupied by a planet among them that is placed in an angle. If there is none such, a journey should be predicted in the direction of the ninth sign. This is a special rule. [And] Caṇ̣eśvara [says]:

If Mercury or Venus, endowed with strength, occupies a trine from the ascendant in the year, [a native] residing at home will go abroad, [while] one residing abroad will return home. If a benefic occupies the fourth [or] tenth house, then there will not be a journey. If a malefic is there, [there will be] a journey, [but] not if the planet is retrograde.

Should the ruler of the ninth house occupy the ascendant or, in particular, occupy [the place of] the moon, [or if] the moon and the ruler of the ascendant are in the ninth house, then too there is an unplanned journey. [If] the moon or the ruler of the ascendant comes into contact with planets [occupying] angles, then even if a journey has been arranged, it is certain that [there will be] no journey.

If the ruler of the seventh house occupies the ninth house, a wise [astrologer] should predict an inevitable journey. If the angles are in movable signs, joined by benefics, he should predict a certain journey to a village or the like; if it is joined by malefics, it will happen after 
carasvabhāvād daśamād aśubheśanirīkșaṇāt |

aśubhekșaṇayogāc ca prayāṇam iti kathyatām \|

udayadyūnacandrāṇām kartarī pāpasambhavā |

yātrāyām ca tadā vācyam bhayam caurārisambhavam |

kartarì śubhasambhūtā gamanapratibandhikā \|

hillājaḥ |

tritiyadharmago bhaumo naștaviryah śaneh pade | punyanāśakarah sūryo varșeśo hīnavīryavān \| tridharmagah pāpakaro nașto mando 'bdapas tathā | mando 'bdapas tridharmastho dharmado balasamyutah \| gurus tridharmago 'bdeśo nayād dravyakaro balah | munthā tridharmagā punyapradā pāpayutānyathā| dagdhe naște krūrayute dharmeśe jñātināśanam ||

jīrṇatājike |

mūrtị̣ mūrtipatih paśyed bhāgyaṃ paśyati bhāgyapaḥ| bhāgyam lagnapatir lagnaṃ bhāgyapah paśyati dhruvam || bhāgye lagnapatis tișthel lagne bhägyapatiryadā | bhāgyalagnapatī svarkșe varșe bhāgyodayo bhavet \|

atha navamabhāvasthitānāṃ sūryādīnāṃ phalāni padmakośe |

3-5 sambhavā ... śubha] om. G 4 sambhavam] śastrajam K T M 5 bandhikā] baṃdhakā KT 7 śaneh] śanaiḥ M 8 varșeśo] varșeśī N 11 nayād] nụpād KTM 12 puṇya] punyyā B 17 lagna] lagne $\mathrm{T} 18$ patī] patau B N G 19 navama] nava $\mathrm{K}$ 
a long time. ${ }^{135}$ From a malefic aspecting from the tenth, [falling in a sign] of movable nature, and from a joining to malefic aspects, a journey should be predicted. [If] malefics cause besiegement ${ }^{136}$ of the ascendant, the seventh house [or] the moon, then danger from robbers and enemies ${ }^{137}$ during the journey should be predicted. A besiegement caused by benefics will prevent [the person] from leaving.

[And] Hillāja [says]:

Mars having lost its strength and occupying the third or ninth house in the place of Saturn destroys piety. The sun as ruler of the year, possessing little strength, occupying the third or ninth house, causes evil; likewise a corrupt Saturn as ruler of the year. [But] Saturn as ruler of the year endowed with strength, occupying the third or ninth house, grants piety. Jupiter as ruler of the year, occupying the third or ninth house and endowed with strength, makes wealth through prudence. ${ }^{138}$ The munthaha occupying the third or ninth house bestows piety; the reverse if joined to malefics. If the ruler of the ninth house is burnt, corrupt [or] joined to malefics, there is destruction of relatives.

[And] in the Jirnatäjika [it is said]:

Should the ruler of the ascendant aspect the ascendant [while] the ruler of the ninth house aspects the ninth; [or] indeed [if] the ruler of the ascendant aspects the ninth house [and] the ruler of the ninth, the ascendant; [or] when the ruler of the ascendant should occupy the ninth house, [or] the ruler of the ninth, the ascendant; [or if] the rulers of the ninth house and the ascendant are in their domiciles, in [that] year fortune will dawn.

Next, the results of the sun and other [planets] occupying the ninth house [are described] in [Tājika] padmakośa [1.9, 2.9, 3.9, 4.9, 5.9, 6.9, 7.9, 8.9]:

135 It is not clear what should be joined by malefics - possibly the ninth house and/or the ruler of the seventh.

136 In Sanskrit, kartarī, lit. 'scissors'; cf. Chapter 5, note 79.

137 Text witnesses K T M add: 'and weapons'.

138 Text witnesses K T M read: 'from the king'. 
dharmasthito 'rkaś ca sahodarānām pịdākaraḥ kleśavivardhanaś ca| dharmaprado rājyayaśahpradaś ca tadvarșamadhye svadaśām gataś cet || punyodayaṃ dharmagatah śaśäñko bhāgyodayam cārthasamāgamaṃ ca | svagehasaukhyam ca ripor vināsaṃ vyāyāmasaukhyam ca karoti varșe \| dharmam gate bhümisute ca varșe puṇyodayo vittasamāgamaś ca | bhāgyodayo mānavivardhanam ca mahāpratișthāmbaralabdhir atra \| dharmasthitậ śaśisutah sutaläbhasaukhyam arthāgamam satatamañgalam āśu kuryāt | bhüpäjjayo bhavati kìrtivivardhanam ca bhāgyodayo ripuvināśanam atra varșe \| vācaspatir dharmagato narānām karoti dharmam bahulạ̣ sukham ca| bhāgyodayam cārthasamāgamam ca tīrthāțanam punyamatim prakuryāt || dharmasthito dharmakarah kavih syān narendratulyam ca naram karoti $\mid$ sukhaprado vāhanabhūṣaṇānām gobhūhiraṇyāmbaralābham āśu\| bhāgyodayo bhāgyagataḥ śaniś ced bhūyo 'rthadah śatruvināśadaś ca | kīrtiśriyam mānam athāpi datte sahodarānāàm abhayārtidaś ca \| dharmasthito dharmavivardhano 'gur jayaṃ nrpāc chatruvināśanaṃ ca | bhāgyodayaṃ cārthasamāgamaṃ ca karoti pị̣̂ām paśubāndhaveșu\| maṇitthah |

3 gatah] gate $\mathrm{G} \|$ śaśāniko] śaśāṃke $\mathrm{G} \|$ samāgamaṃ] samāgamaś B N $\quad 5$ dharmaṃ] dharme B N || puṇyodayo] punyyodayaṃ B N $10 \mathrm{ripu}$ ] ri N 12 bhāgyodayaṃ] bhāgyodayaś K; bhāgyodayapraś T 15 bhāgyodayo] bhāgyodayam B N K T M \| vināśadaś] vināśanaś K T M 16 kīrti] kīrtiś K T; kīrtiṃ M \| abhayārtidaś] bhayam ārtidaś G K T M

1-2 dharma ... cet] TPK $1.9 \quad 3^{-4}$ puṇyodayam ... varșe] TPK $2.9 \quad 5^{-6}$ dharmam ... atra] TPK 3.9 7-10 dharma ... varșe] TPK 4.9 $\quad 11-12$ vācaspatir ... prakuryāt] TPK 5.9 $\quad$ 13-14 dharma ... āśu] TPK $6.9 \quad$ 15-16 bhāgyodayo ... ca] TPK 7.9 17-18 dharma ... paśubāndhaveșu] TPK 8.9

4 sva ... varṣe] In the place of this half-stanza, G K T M read: tìrthātanam bhümipateś ca lābham śubhekșitah (śubhekșite $\mathrm{G}$ ) putrasukham sitenyat (site 'nyat $\mathrm{G}$ ). 6 atra] At this point, $\mathrm{B} \mathrm{N}$ add a half-stanza not found in independent witnesses of the TPK: räjyārthaläbham ca mahāpratișthām karoti mānaṃ paśughātanạ̣ ca. 
Occupying the ninth house, the sun makes suffering for siblings and increases distress, [but] it grants piety, dominion and renown in that year if it occupies its own period. ${ }^{139}$

The moon occupying the ninth house makes a dawning of piety, a dawning of good fortune and acquisition of wealth; happiness in one's own home, the destruction of enemies, and happiness from exercise. ${ }^{140}$

If Mars occupies the ninth house in the year, there is a dawning of piety here, and acquisition of wealth; a dawning of good fortune and increase in honour; attainment of great eminence and [fine] garments. ${ }^{141}$

Occupying the ninth house, Mercury swiftly makes happiness from having children, ${ }^{142}$ acquisition of wealth and constant good luck. There is triumph on account of the king, increase in renown, dawning of fortune and destruction of enemies in this year.

Jupiter occupying the ninth house produces piety and abundant happiness for men: it will bring about a dawning of fortune, acquisition of wealth, pilgrimage and a pious inclination.

Occupying the ninth house, Venus will produce piety, and it makes a man equal to a king; it bestows happiness from vehicles and ornaments [and] swiftly [brings about] gain of cattle, land, gold and garments.

Fortune dawns if Saturn occupies the ninth house; it gives wealth in plenty and the destruction of enemies. It even gives [the native] splendid renown and honour and gives siblings freedom from danger and distress.

Occupying the ninth house, Rāhu increases merit; it makes triumph on account of the king, destruction of enemies, dawning of fortune and acquisition of wealth, [but also] suffering to cattle and kinsmen.

[And] Manittha [says]:

\footnotetext{
139 Or 'its own condition' (daśā). Meaning unclear.

140 Presumably gymnastic exercise, though other forms are possible as well. Text witnesses G K T M replace the latter part of the sentence with: 'pilgrimage and gain from the king; happiness from children if aspected by benefics, [but] different if [the moon is] waxing'.

141 Text witnesses B N add: 'It makes gain of power and wealth, great rank and honour [but] killing of cattle.'

142 Or 'from children and gains'.
} 
jāyāputravivādam ca matir dharmakriyādișu| cittodvegākulam nityam navame tapano yadi $\|$ navame dharmalabdhiś ca manahsaṃtoṣam eva ca | yaśovṛddhir nrpān māno varșādau ca niśākare \| pāpalabdhir bhavet pumsām udvegam vibhavakșayam |

kalaham bandhuvargaiś ca navame dharan̄isute || dharmabuddhis tathodvegam dainyam jāyāprapịdanam | candrajạ kurute varșe navamastho yadā nṛnām \| dhanalābho rājyasaukhyam dharmakāryam bhavet sadā | prāpnoti vividhān bhogān devejye navamasthite \| śarìre caivam ārogyam sadbuddhir vibhavāgamam | putrajāyādikam saukhyaṃ navame bhrguje nṛ̣ām || jāyāputrasuhṛtkaștam dhananāśam nrpād bhayam | durmatih pāpabuddhiś ca navame bhāskarātmaje \| vidveșaś ca vapuhpièdā dainyam rājādipịdanam | dharmakārye vilambaś ca rāhur dharmagato yadi ||

iti navamabhāvavicārah ||

atha daśamabhāvavicāraḥ | tatra daśamabhāve kị̣ cintanīyam ity uktaṃ caṇ̣eśvareṇa |

ākāśavrttāntajalaprapātaḥ sthānaṃ pitụ̣ kāryasukhādi mānam | punyam nrpatvam ca tathādhikāro mudrā cyutis tad daśame vicintyam \|

2 tapano] tapane B N G 6 kalahaṃ] kalaho M \|| vargaiś] vargaś B N 10 prāpnoti] prāmoti N 17 bhāvavicāraḥ] bhāvaḥ B N 18 daśama ${ }^{1}$ ] dama B 21 cyutis] śrutis G 
There are disputes with wife and children, inclination towards pious acts and so on, and the constant affliction of an agitated mind, if the sun is in the ninth.

If the moon is in the ninth at the beginning of the year, there is attainment of merit, contentment of mind, increase of renown and honour from the king.

If Mars is in the ninth, men meet with evil; there is agitation, loss of fortune, and quarrels with kinsmen.

Inclination towards piety, and likewise agitation, wretchedness and suffering to one's wife: [this] Mercury produces for men when occupying the ninth.

There will always be gain of wealth, happiness from dominion, and acts of piety, and [the native] obtains various pleasures, when Jupiter occupies the ninth.

Likewise, men have a healthy body, good understanding, acquisition of fortune, and happiness in the form of children, wife and so on, when Venus is in the ninth.

There are evils to wife, children and friends, loss of wealth, danger from the king, foolishness and evil inclination, if Saturn is in the ninth.

There is hatred, suffering of the body, wretchedness, suffering from the king and so on, and idleness with regard to pious acts, if Rāhu occupies the ninth house.

This concludes the judgement of the ninth house.

\subsection{The Tenth House}

Next, the judgement of the tenth house. Concerning that, Candeśvara describes what is to be considered from the tenth house:

Celestial events, fall of water, ${ }^{143}$ the father's position, happiness from work and so on, honour, merit, kingship, authority, [an official] seal and falling: ${ }^{144}$ that should be considered from the tenth.

143 This compound is attested in the sense of 'waterfall', but could also conceivably relate to precipitation.

144 Text witness G reads 'learning' (lit. 'hearing'). 
atrāpi pūrvavad vicāraḥ | atha yogāḥ | vāmanaḥ |

varșeśvare gaganage rājyāptiḥ syād balānvite |

bhavet sthānāntaraprāptir anyakendragate sati $\|$

varșeśo 'rkaś caturthasthaḥ pürvārjitapadāptidaḥ|

varșeśo 'rko lābhagatah sakhyam syān nrpamantribhị̣ ||

varṣeśah sūryo lagnago daśamastho vā rājyadaḥ syād iti yādavaḥ |

varșeśvare vā mihire 'tha lagnakhasthe savirye kularūparājatā $\|$

nīcasthe krūrayukte 'rke khasthe syād bandhanam nrpāt $\|$

samarasiṃhah |

lagne gagane 'tha ravisthāne muthahāgame hi rājyāptị̂ | candre bhaumasthāne sthānāntarakārakatvam syāt |

atra varṣeśaś candro daśamago bhaumasthāne sthānalābhado bhavatīty āha yādavaḥ |

iläjabhasthite |

samāpatāv abdanabhoniśākare parāspadāptis tv iha varșaveśane \| iti

7 varșeśvare] varșeśvaro $\mathrm{G} \|$ khasthe] khasthite $\mathrm{BN}$; svasthe $\mathrm{M} \quad 8$ khasthe] svasthe $\mathrm{M} \quad 10$ sthāne] pada G || āgame] āgamane G || rājyāptiḥ] rānyāptiḥ N $\quad 12$ sthāne] om. T M 13 atra] atha K T M || varșeśaś] varșeśa B N || lābhado] balī yadā B N 15 bhasthite] bhasthe B N K M 16 samāpatāv abdanabho] sapāpatāv avdanabho N; cavabhau K; canabho M

7 varṣeśvare ... rājatā] TYS $12.105 \quad$ 15-16 ilāja ... veśane] TYS 12.106 
Here, too, judgement is [to be made] as before. Now, configurations; [and] Vāmana [says]:

If the ruler of the year occupies the tenth house endowed with strength, [the native] will attain dominion; if it occupies another angle, he will move to another place. The sun as ruler of the year occupying the fourth gives rank previously earned; [if] the sun as ruler of the year occupies the eleventh house, there will be friendship with the king's counsellors.

Yādava says [in Tājikayogasudhānidhi12.105] that the sun as ruler of the year occupying the ascendant or the tenth will give dominion:

Or if the ruler of the year is the sun, occupying the ascendant or midheaven in strength, there is dominion according to one's family community.

[Vāmana continues:]

if the sun in the midheaven occupies its fall, joined to a malefic, there will be captivity [ordered] by the king.

[And] Samarasiṃha [says in the Tājikaśāstra]:

If the munthahā comes to the place of the sun in the ascendant or the tenth house, [the native] attains dominion; if the sun occupied Leo in the nativity and is strong in the year, he assumes the rank of [his] master. If the moon is in the place of Mars, it will cause a change of place.

Concerning this, Yādava says [in Tãjikayogasudhānidhi12.106] that the moon as ruler of the year occupying the tenth in the place of Mars makes [the native] gain a position:

If the moon as ruler of the year in the tenth house of the year occupies the sign [housing] Mars [in the nativity, the native] attains the position of another in this revolution of the year.

[Continuing from the Tājikaśāstra:] 
mandasthāne bhaume paśyati muthahāṃ kukarmajā nṛabhịh \|

daśamabhavane ete yogā iti kecit |

gaganapavarșapalagnapadaśādhiśānām muthaśile hi rājyāptị̣|

nrpasahamage 'bdanāthe ravītthaśāle ca nrpayogah $\|$

rājyaprāptipraśne lagneśe śaśinā ca nabhahpatinā |

krtamuthaśile 'mbaradrśá rājyam tūpakramād bhavati \|

anyonyabhavanagamanāt krūrābhāve 'py acintitaprāptị̣|

lagnasthānyena ca saumyenāmbarapasya muthaśile 'py evam \|

pāpārdite tu mande nikațībhūyottaraty atho rājyam |

bhūmisthe krūradrśā tv apavādah śubhadriśā kīrtih \|

mandagrahe balavati krūraviyukte yadā śaśi vibalaḥ|

mande balini bhramaṇād rājyaprāptir bhavet praștuh \|

lagnādhipatau svagrhe lābho räjyasya tungage bhümeh |

bahvyā muśallahe punar alpāyā niradhikārini parasya \|

lagnāmbarādhipau yadi makabūlau kendragendumuthaśilataḥ|

makabūlaś candro 'py atha nijagṛhahadde tathāpi syāt \|

makabūle kendram ṛte naște vā naiva rājyaläbhah syāt |

makabūlam rrte 'pi syād balavati candre kramād rājyam \|

candre vibale na syād yadi cendụ̣ krüravarjito 'nyena |

daśamadrśendūvāraṃ kurute tat kiṃcid āpnoti $\|$

1 muthahāṃ] muthahā M || kukarmajā] kukarmatā G K T M 3 lagnapadaśā-] lagnā- K T M 4 sahamage] sahame B N; sahamape K T M \|| nāthe] nārtha N \| ravīttha-] rarvitthaN; rattīttha- K T M $\quad 5^{-20}$ rājya ... āpnoti] om. B N K T M 8 lagnasthānyena] scripsi; lagnasthonyena $G \|$-barapasya] scripsi; -vararapasya $G \quad 12$ balini] scripsi; balena $G \quad 16$ hadde] scripsi; haddake G 20 dṛśendūvāraṃ] scripsi; dṛ́saādir dvāraṃ G

3 gaganapa ... rājyāptiḥ] This half-stanza, while comprising 33 morae, does not conform to the metric pattern noted above. Emending daśādhissānām muthaśile to the homosemous daśādhipānām mutthaśile would remedy this.

145 Text witnesses K T M omit 'and the ruler of the period'.

146 Text witnesses K T M read 'rules'.

147 This and the following paragraph, found only in text witness G, appear properly to relate to interrogational astrology rather than annual revolutions. 
If Mars in the place of Saturn aspects the munthaha $\bar{a}$, there is danger from the king due to misdeeds.

Some say that these configurations [should take place] in the tenth house. [Continuing from the Tãjikaśāstra:]

If there is a mutthasila of the ruler of the tenth house, the ruler of the year, the ruler of the ascendant, and the ruler of the period, ${ }^{145}$ [the native] attains dominion. If the ruler of the year occupies ${ }^{146}$ the sahama of king[ship] in an itthaśála with the sun, it is a royal configuration.

In a question on attaining dominion, if the ruler of the ascendant forms a mutthaśila with the moon and with the ruler of the tenth house by a tenth-house aspect, [the querent] wins dominion by [his own] effort. ${ }^{147}$ But by [those planets] occupying each other's house in the absence of malefics, he attains it unexpectedly; likewise if the ruler of the tenth house has a mutthaśila with a benefic placed elsewhere than in the ascendant. But if the slower [planet] is afflicted by a malefic, he comes close to dominion but loses it. If [the slower planet] occupies the fourth house with a malefic aspect, there is censure; with a benefic aspect, renown, if the slower planet is strong and free from the malefics. When the moon is weak while the slower planet is strong, the querent attains dominion after [initial] failure. ${ }^{148}$

If the ruler of the ascendant is in its domicile, there is gain of dominion; if it occupies its exaltation, of much land; if in its musallaha, of a little; if it is without authority, of something alien. ${ }^{149}$ If the rulers of the ascendant and the tenth house have a makabüla through a mutthaśila with the moon occupying an angle, and the moon, [while forming the] makabüla, is in its own house or hadd $\bar{a}^{150}$ then too [the gain of dominion] will come to be. [However], in a makabüla without [occupying] an angle, or if [the moon] is corrupt, there will be no gain of dominion; [but] if the moon is strong, dominion will be [gained] eventually even without a makabüla. If the moon is weak, it will not happen; but if the moon, free from malefics, makes an induvāra with another [planet] by a tenth-[sign] aspect, then [the querent] gains [at least] something.

148 The most likely intended meaning. More literally, 'wandering' or 'erring'.

149 Again, the most likely intended meaning, unless the reading is corrupt.

$15^{\circ}$ But the moon has no terms ( haddā), as these are divided only among the five true planets. Cf. Chapter 3, note 33 . 
jīrṇatājike |

daśamādhiśvarah sūryo janmakāle 'bdaveśane |

daśamastho vilagneśetthaśālo rājyadāyakah ||

pāpārdito naștabalo rājyeśo rājyanāśadah |

śanau sāre 'dhikāreṇa hīne vyākulatā bhavet ||

tejahsimhhạ |

janmāñgapo 'bdasamaye yadi karmanāthạ

karmeśvaro januṣi lagnapatiś ca varșe |

karmāñgadrșțiyutitah sabalaḥ padāptim

kuryāt tadety akhilabhāvaphalaṃ vilokyam \|

vyomābdape 'bdajanușoś ca hate vyayāșta-

dvițsthe 'śubhe iha hi nānyaśubhe 'pi yoge |

karmāśrite sahamape śanidrșțiyukte

karmakșatir daśamape 'pi vinașțadagdhe \|

varșatantre |

svarkșoccage karmaṇi sūryaputre nairujyam arthādhigamaś ca jīve | sūrye nrpād bāhubalāt kuje 'rtho budhe bhișagjyotișakāryaśilpaih || șậștaryayage 'bdeśe karmeśe ca balojjhite | sūtāv abde ca na śubham tatrābde mritipe tathā $\|$

yādavaḥ |

3 daśamastho] daśamasthe B N \|| -śālo] -śālī G K T M 5 śanau sāre] scripsi; sāre śanau B N G K T M 9 yutitah] patitah B N; yujitaḥ G 12 dvițsthe] dvisthe T M \|| hi nānya] dinānya G 13 dṛști] dṛsța G K T M 17 budhe] dudhe N

7-10 janmā ... vilokyam] DA 28.12 13-14 karmāśrite ... dagdhe] DA 28.6 16-17 svarkṣoccage ... śilpaih] VT 16.4 18-19 șạ̣ ... tathā] VT 16.7 
[And] in the Jirnatäjika [it is said]:

The sun, ruling the tenth at the time of the nativity and occupying the tenth in the revolution of the year, in an itthaśa la with the ruler of the ascendant, gives dominion. The ruler of the tenth house afflicted by malefics, having lost its strength, puts an end to dominion. If Saturn is with Mars, bereft of dignity, there will be agitation.

[And] Tejahsimịha [says in Daivajñālaṃkrti 28.12, 6]:

If the ruler of the ascendant in the nativity rules the tenth house at the time of [the revolution of] the year, and the ruler of the tenth house in the nativity rules the ascendant in the year, then by aspecting or joining the tenth house [or] the ascendant in strength it will make [the native] attain rank. The results of all the houses should be considered thus.

If the ruler of the tenth house and the year ${ }^{151}$ is afflicted in the nativity and the year, occupying the twelfth, eighth or sixth house and [being] malefic, and there is no other benefic configuration present, ${ }^{152}$ and if the ruler of the sahama occupies the tenth house joined to the aspect of Saturn, ${ }^{153}$ there is failure in undertakings; or if the ruler of the tenth is corrupt and burnt.

[And] in Varșatantra $[16.4,7$, it is said]:

If Saturn occupies the tenth house in its domicile or exaltation, there is good health; if Jupiter [does so], acquisition of goods; if the sun, wealth from the king; if Mars, from the strength of one's arms; if Mercury, by medicine, astrology, poetry and craftsmanship.

If the ruler of the year occupies the sixth, eighth or twelfth house as ruler of the tenth house, bereft of strength in the nativity and in the year, there is no good in that year; likewise if it rules the eighth house.

[And] Yādava [says in Tājikayogasudhānidhi 12.110, 109, 108, 107]:

151 This word, given in the singular, necessarily refers to a single planet.

$15^{2}$ The phrasing is syntactically awkward in addition to deviating from standard sandhi or phonological rules. In available independent witnesses of the Daivajñălaṃkrti, the stanza reads differenty.

153 Text witnesses G K T M read 'aspected or joined by Saturn'. 
dravyeśena samāsujanmani tanūnāthetthaśāle tathā dravyeśasya samāngapena śubhayunimuntheśvarasyāpi vā | varșeśena januhhkhapena ca tathā yoge tu rājyādikam sūrye khe 'nadhikārake janitanūpādyair yute vāpi tat \| varșāngād daśame tu rājyasahame saumyākșiyukte tadā tadvrddhir janivarșakhasthitaravau lagneśayoge 'gryake | tadvajjanmani karmape 'bdakisimam yāte ca tatpe samākarmeśe janisādape samudite drșțe yute taddvaye \| janau khape vā nrpasādape vā samudgate rājyapadāptigauravam | samāpatau janmanabhomahībhujā samūthaśîle 'tha nabho'ñganāthayoh | svavamíamānena nrpatvalabdhị sāde śubhe 'bde janane 'pi rājyam \|

\section{hillājaḥ |}

varșeśvare ravau candrasthānage ravinandane | janmābdakālayoh pāpākrānte syāt karmanāśanam \| tādríse ca śanau vakre dagdhe nișphalatā bhavet | sarvakarmasu karmeśakarmabhāvau śanīkșitau| yuktau vā karmavaikalyam karmasadmaphalam tathā $\|$

\footnotetext{
1 nāthettha-] nārthattha- $\mathrm{N} \quad 2$ dravyeśasya] dravyeśena K T M \| samāngapena] samāngape B N || śubhayun்] śubhayute B N 4 khe] sve M \|| -pādyair] pāpai T; pāpair M \|| yute] yutai T || vāpi] cāpi G K T 6 sthita] sthiti K T M \|| 'gryake] nyake B N; grake K M; gnake T 7 kisimaṃ] kisibhaṃ B N || tatpe] tasthe K; tatsthe M \| samā] samo N 8 sādape] sādaye M \| tad] ca G K T M 9 janau] śanau B N \| sādape] sādmape; sādaye M B 10 samūthaśile] sumūthaśíle B N || 'tha nabho'ñga] dhanabhoga B N 11 labdhiḥ] labdhitā K T M 15 tādṛśe] tadīśe B N

1-4 dravyeśena ... tat] TYS $12.110 \quad 5^{-8}$ varșāngād ... dvaye] TYS $12.109 \quad 9$ janau ... gauravam] TYS $12.108 \quad$ 10-11 samā ... rājyam] TYS 12.107
}

1-8 dravyeśena ... dvaye] These two stanzas are misnumbered as 109 and 108, respectively, in MS TYS 1 (following the actual verse 108). 
If the ruler of the ascendant of the nativity is in an itthaśăla with the ruler of the second house in the year, or, likewise, if the ruler of the second house [forms an itthaśála] with the ruler of the ascendant of the year, or the ruler of the munthaha, joined to a benefic, [does so] with the ruler of the year and the ruler of the tenth house of the nativity, in such a configuration there is dominion and so on, or if the sun is in the tenth house [even] without dignity, joined to the ruler of the ascendant of the nativity and so forth.

And if the sahama of dominion is in the tenth from the ascendant of the year, joined to the aspects of benefics, that [signification] flourishes, [or] if the sun, occupying the tenth house of the nativity or the year, forms the foremost configuration with the ruler of the ascendant. ${ }^{154}$ Likewise if the ruler of the tenth house of the nativity occupies the kisima of the year, and its ruler [is] the ruler of the tenth house of the year [or] the ruler of the lot in the nativity, [and] the two are [heliacally] risen [and] joined or aspected [by each other]. ${ }^{155}$

If the ruler of the tenth house in the nativity, or of the lot of king[ship], is [heliacally] risen, there is the dignity of attaining royal dignity.

If the ruler of the year has a mutthasila with the ruler of the tenth house of the nativity, or if the rulers of the tenth house and the ascendant [of the year do so, the native] gains dominion in accordance with his lineage. If a benefic is on the lot both in the year and in the nativity, there is dominion.

[And] Hillāja [says]:

If the sun as ruler of the year occupies the place of the moon, and Saturn is beset by malefics at the times of the nativity and of the year, there is destruction of [the native's] work. ${ }^{156}$ And if such a Saturn is retrograde or burnt, all his works will fail. [If] the ruler of the tenth house and the tenth house [itself] are aspected or joined by Saturn, there are defects in his work; the result of the lot of work is the same.

154 That is, an itthaśála or applying aspect.

155 The indiscriminate use of the locative absolute makes the precise meaning of this passage somewhat uncertain. Kisima or kisimā is the Sanskritized form of Arabic qisma 'division', used in the context of directions (tasyir ) to designate the time during which a significator (dalil) symbolically moves through a given set of terms.

156 Or: 'If the sun is ruler of the year and Saturn, occupying the place of the moon, is beset by malefics'. 
lagnādhipena vārkeṇa itthaśālaṃ karoti cet |

daśameśas tadā varșe 'vaśyam syān nrpadarśanam ||

karmeśasyāgrato yātauyadā lagnapabhāskarau|

khago lagneśvaro vā syān nrppeña saha samgamah \|

cūḍāmaṇau |

lagneśaḥ svoccanāthena tungādisthena vīkșitah |

abhiștapadaläbhāya lagne lagneśvare tathā $\|$

saumyasvāmiyute drșțe padaprāptih sthire tathā |

evam eva padasthāne vrścike svalpasiddhikrt \|

udite rājyape rājyam caravarjyam śubhagrahaị̣ |

padasthairyam yute dṛște krūraiś cāpi padacyutih \|

padeśaś cet padam paśyet padam tasya sthiram bhavet |

lagnanāthapadādhyakșāv anyonyam yadi paśyatah $\|$

lagnanāthanabhonāthacandrā vyomni padārthadāh |

svocce lagne subhah khețạ saumyadrștah padapradah ||

saptame cāștame śukre padalābhah svabhāvataḥ|

budhena guruñā vāpi yukte śukre mahat padam \|

sacandre svāminah prìtyā sakuje kalahāditaḥ|

padam naiva sasaure syāt sārke mithyā tu tat padam \|

padasiddhiḥ subhair yukte pāpayukte padacyutiḥ |

sthirodaye padaprāptị̣ śubhasvāmiyutekșite \|

ittham eva padasthāne sā svalpā kiṃtu vrścike |

lagnanāthanabhonāthau candrāḍhyau ca padapradau \|

madhyape saśubhe rājyam rājyabhraṃśạ sapāpake |

padāvāptir bhavec chīrșodaye lagne śubhānvite \|

1 vārkeṇa] vārșeṇa B N; vā kena G 11 dṛștẹ] khe add. G || cāpi] ca G 14 padārthadāḥ] padārthadaḥ B N G 15 khețaḥ] khețo BN $\|$ pada] śubha B N 17 vāpi] cāpi N 18 kalahāditaḥ] kalahārditạ̣ M 19 sasaure] sasāre B N \| sārke] tu add. B N; sārkair K T; sārker M 23 candrāạhyau] cāṃdrādyau N || pada] phala K T 24 saśubhe] sarśubhe B N 
If the ruler of the tenth makes an itthaśāla with the ruler of the ascendant or with the sun, [the native] will certainly see the king in that year. When the ruler of the ascendant and the sun stand in front of the ruler of the tenth house, or if the ruler the ascendant occupies the tenth house, he will have encounters with the king.

[And] in the Cüdāmani [it is said]:

The ruler of the ascendant aspected by the ruler of its exaltation, [that ruler] occupying its exaltation and so on, makes for attainment of the desired rank. Likewise, if the ruler of the ascendant is in the ascendant, joined to benefics and its ruler [or] aspected [by them], there is attainment of rank; likewise [if it is] in a fixed [sign]. [But] if Scorpio thus occupies the tenth house, it makes slight success. If the ruler of the tenth house is [heliacally] risen, there is dominion; if it is joined to or aspected by benefics, avoiding the movable [signs], there is stability of rank, but if by malefics, fall from rank. ${ }^{157}$ If the ruler of the tenth house should aspect the tenth house, his rank will be stable, [or] if the ruler of the ascendant and the ruler of the tenth house aspect each other.

The ruler of the ascendant, the ruler of the tenth house and the moon in the tenth house give rank and wealth; a benefic planet in its exaltation in the ascendant, aspected by benefics, bestows rank. If Venus is in the seventh or the eighth, [the native] wins rank by his own nature; if Venus is joined to Mercury or Jupiter, there is great rank. If it is with the moon, [he attains rank] by the affection of his master; if with Mars, through fighting and so on; if with Saturn, there will be no rank; if with the sun, that rank [turns out to be] false.

There is attainment of rank if [the tenth house] is joined by benefics, fall from rank if joined by malefics. If a fixed [sign] rises, aspected by benefics and its ruler, [the native] wins rank, and likewise for the tenth house; but in Scorpio, that [attainment] is slight. The ruler of the ascendant and the ruler of the tenth house joined to the moon bestow rank. If the ruler of the tenth house is with a benefic, there is dominion; fall from dominion if it is with a malefic. If the ascendant is [a sign] rising with its head, occupied by benefics, [the native] attains rank. ${ }^{158}$

157 Text witness $\mathrm{G}$ reads: 'if by malefics in the tenth house'.

$15^{8}$ The signs rising with their heads are Gemini, Leo, Virgo, Libra, Scorpio and Aquarius; see Brhajjātaka 1.10. This is a classical Indian rather than a Täjika classification. 
samarasiṃhạ |

daśamasvāmì lagne paśyati lagnaṃ nrpāal lābhaḥ|

rājñaś cittam kìdrk tatrāpi vinirdiśed evam \|

lagneśadaśamapatyoḥ snehadṛśā syāc chubham cittam |

krūradrśā viparītạ̣ drștyābhāve ca madhyamam proktam \|

anyatrāpi |

svakīyasvāminā sārdham prītir vrṣatulālini |

lagne 'vaśyam samādeśyā kanyālagne ca madhyamā \|

anyeśo mama bhavitā na veti lagneśvarasya yadi kendre |

no bhavati mūthaśilam tatpatinā syāt tadā nānyạ̣ \|

vakrī cānyena samam lagnapatih sahajanavamasamsthena|

kurute yadītthaśālaṃ tadānyanātho bhavet prașțh \|

ayam iśo me bhavyo prcchāyām lagnapasya makabūle |

svāmì sa eva bhavyo dyūneśasya ca śubho 'nyeśah \|

tatrendunā musariphe 'phalapradaś cetaro bhavet phaladaḥ|

krtamuthaśile ca candre makabūle nārthitaś ceśạ \|

athavoktayogabāhyam lagneśo 'stādhipo 'tha tatrarkșe |

tatrasthe kambūle sa eva bhavyo 'nyathā cānyaḥ || iti |

atha daśamabhāvasthitānāṃ sūryādigrahāṇāṃ phalāni padmakośe |

2 daśama ... paśyati] daśamasvāmilagnapatir B N || lābhaḥ] lābhaś B N $\quad 3-5$ rājñaś ... -bhāve] om. B N 3 evam] daivam M 7 tulā-] jhașā- G 8 lagne $^{2}$ ] lābhe B N; lagnam K 9-18 anyeśo ... iti] om. B N K T M 15 'phalapradaś] scripsi;'phaladaś G 17 tatrarkṣe] scripsi; trarkṣe G 19 sūryādigrahāṇāṃ] arkādīnāṃ G 
[And] Samarasiṃha [says in the Tājikaśāstra]:

[If] the ruler of the tenth is in the ascendant [or] aspects the ascendant, there is gain from the king. What is the king's [frame of] mind like? Concerning that, one should predict as follows: by a benefic aspect between the ruler of the ascendant and the ruler of the tenth, his [frame of] mind will be good; by a malefic aspect, the reverse; and in the absence of an aspect, it is said to be middling.

And elsewhere [it is said]:

With regard to one's own master, affection is certainly to be predicted if the ascendant is Taurus, Libra ${ }^{159}$ or Scorpio; in Virgo ascendant, it is middling.

[Continuing from the Tãjikaśāstra]:160

'Will I get another master or not?' If [someone asks thus and] the ruler of the ascendant, [placed] in an angle, does not form a mutthaśila with its ruler, then there will be no other [master]. [But] if the ruler of the ascendant is retrograde and forms an itthaśäla with another [planet] occupying the third or ninth house, then the querent will have another master.

'Is this master good for me?' In [such] a question, if the ruler of the ascendant has a makabüla, that very master is good; but if the ruler of the seventh house has [a makabüla], another master is favourable. Concerning that, if [the ruling planet forms] a müsarihpha with the moon, it will not give its result, but otherwise, it will. And if it forms a mutthaśila and a makabūla with the moon, a master is not sought.

Or else, [even] without the configurations related, [if] the ruler of the ascendant or the ruler of the seventh house is in that sign, and there is a kambüla there, that very [master] is good; if [it is] otherwise, another.

Next, the results of the sun and other planets occupying the tenth house [are described] in [Tājika] padmakośa [1.10, 2.10, 3.10, 4.10, 5.10, 6.10, 7.10, 8.10]:

159 Text witness G reads 'Pisces'.

16o The following quotation is found only in text witness G. It appears to relate to interrogational astrology rather than to annual revolutions. 
yadā dineśo gaganāśritaḥ syād rājyārthado mānavivardhanaś ca | hiraṇyabhūmyambaralābhakārī catuṣpadāngeș̣u rujo viṿ̛ddhị̣ \| karmodayam prakurute gagane śaśäniko dravyāgamaṃ nrpakulād ripupakșanāśam | vyāpārato bahusukhaṃ mahatīm pratișțām kìrtịn tathā dhanayutām prakaroti varșe $\|$ karmasthito bhütanayo 'bdamadhye karmodayam cārthasamāgamam ca | rājyārthalābham ca mahāpratișthām karoti mānam paśughātanạ̣ ca \| gaganagah śaśijo yadi hāyane bhavati vāhanasaukhyakaras tadā| sutavivrrddhidhanāśvasamāgamo vilasanam ca tathā nrpater jayaḥ \| vyomni sthitaś cet surarājamantrī hemāmbarāptim ca jayam karoti | bhūpaprasādāt kṣitigodhanāptiṃ syād dhāyane śatruvināśanam ca \| gaganage bhrgunandanasamjñake nrpasamo manujo 'tha mahäjayah | bhavati godhanadhānyasamāgamo bahusukham krșivāhanayoh sadā $\mid$ gaganagạ̣ krșihānikaraḥ śanih paśubhayam svajanodarapịdanam | nrpasamam manujam ca mahādhanam prakurute krayavikrayalābhakrt \| siṃhisuto daśamagạ̣ krayavikrayeșu läbhaṃ naraṃ nrpasamam prakaroti varșe | bhūpājjayam satatamañgalam āśu kuryāt kìrtịn śriyam bhavati vāhanahānikārī||

maṇitthạ |

rājamudrādijaṃ saukhyam siddhārambhah sukham dhanam | prakhyātaṃ vamśavistāraṃ varșe daśamage ravau \| dravyāgamam śatrunāśạ̣ roganāśam tathaiva ca| pratișthā kīrtilābhaś ca varșe daśamage vidhau \|

\footnotetext{
1 yadā] yathā G $\quad 2$ catus ... vi-] catușpadogokhurajādi B N $\quad 6$ yutāṃ] yutiṃ B N $\quad 9$ śaśijo] śiśijo B; śaśino G 10 jayaḥ] jayam K T M 12 prasādāt] prasādā G T 14 sadā] samaṃ G 15 bhayaṃ] janaṃ K T M 17 kraya] kriya B N 23 prakhyātaṃ] prasthānam G 24 śatrunāśaṃ] vastralābhaṃ K T M

1-2 yadā ... vṛddhih] TPK 1.10 $\quad 3^{-6}$ karmodayam ... varṣe] TPK 2.10 $\quad 7-8$ karma ... ca ca $\left.^{2}\right]$ TPK 3.10 9-10 gaganagah ... jayah] TPK 4.10 11-12 vyomni ... ca] TPK 5.10 $13-14$ gaganage ... sadā] TPK 6.10 $\quad$ 15-16 gaganagah ... lābhakṛt] TPK 7.10 $\quad$ 17-20 siṃhī ... kārī] TPK 8.10
} 
When the sun occupies the tenth house, it will give dominion and wealth and increase honour; it makes gain of gold, land and garments, [but] ailments of the body increase among quadrupeds.

The moon in the tenth house brings about a dawning of action, acquisition of goods from a princely family and destruction of the enemy side; it brings about much happiness from one's occupation, great eminence and renown, accompanied by wealth, in [that] year.

Occupying the tenth house in the year, Mars makes a dawning of action and acquisition of wealth, gain of dominion and wealth, great eminence, honour and the killing of cattle.

If Mercury occupies the tenth house in the year, then it makes happiness from vehicles; there is increase of children and acquisition of wealth and horses, pleasures, and likewise triumph on account of the king.

If Jupiter occupies the tenth house, it makes gain of gold and garments, triumph, gain of land, cattle and wealth by the favour of the king; and there will be destruction of enemies in [that] year.

If Venus occupies the tenth house, a man becomes equal to a king and triumphs greatly; there is acquisition of cattle, wealth and grains, and always much happiness from agriculture and vehicles.

Occupying the tenth house, Saturn makes losses from agriculture, danger to cattle, suffering to one's own people and of the stomach; [but] it makes a man equal to a king, of great wealth, and makes gain from buying and selling.

Rāhu occupying the tenth house makes gain from buying and selling and makes a man equal to a king in [that] year; it will bring swift triumph on account of the king, constant celebration, renown and splendour, [but] it makes losses from vehicles.

[And] Manittha [says]:

There is happiness from [documents bearing] the royal seal, successful undertakings, happiness, wealth and a celebrated expansion of the family, if the sun occupies the tenth in the year.

There is acquisition of goods, destruction of enemies ${ }^{161}$ and likewise destruction of illness, eminence and gain of renown, if the moon occupies the tenth in the year.

161 Text witnesses K T M read 'gain of garments'. 
vyāpāraṃ dhanaläbhaṃ ca prasādaṃ bhūmipālatah |

tejovṛddhis tathārogyam daśamasthe mahīsute \|

vānijyād räjavargāc ca dhanaläbham suhṛtsukham |

balam kāntivivrddhiś ca hāyane daśame budhe \|

satkìrtir bhübhṛtām mānaṃ dhanaläbham suhṛtsukham |

gehe mahotsavo nityam devejyo daśame yadi $\|$

nrpamānam suhṛtsaukhyam dhanaläbham ripukșayam |

sarvārambhāh prasidhyanti daityejye daśame nrṇām ||

vyāpārād dhanahāniś ca bhayam bhūpālasambhavam |

sukhe dainyam pravāsaś ca daśame ravinandane \|

bhümināso bhayam nityam dehapị̄̂a dhanavyayah $\mid$

iștasvajanavidveșaṃ rāhau daśamasaṃsthite \|

iti daśamabhāvavicāraḥ ||

atha lābhabhāvavicārah | tatra lābhabhāve kị̣ cintanīyam ity uktạ̣ cạ̣déśvareṇa |

kāryasya siddhị̣ krayavrddhilabdhir gajāśvavastrāsanayānaśayyāh | vidyārthalābho 'py atha naștaläbhaḥ kanyāsuvarṇasya ca lābhakāryam| tarūruhādeh śvaśurādikam ca samastaläbhaḥ khalu lābhabhāve \|

atrāpi pūrvavad vicāraḥ | atha yogāḥ | jīrṇatājike |

3 rāja] rājya K T 4-5 balaṃ ... sukham] om. B N 4 vivṛddhiś] viṿ̛ddhiñ M $\|$ budhe] scripsi; budhah G K T M 5 bhūbhṛtāṃ] bhūbhṛto M 6 mahotsavo] mahotsavaṃ B N \| devejyo] devejye G $\quad$ 7-8 ṇ̣pa ... ṇ̣nām] om. B N 11 vyayạ̣] kṣayạ̣ K T M 13 bhāvavicāraḥ] bhāvaḥ G 16 kāryasya] kārya B || kraya] kṣaya G K T M \| vṛddhi] buddhi B N || yāna] om. B 18 tarū] tanū G K T M 
There is business and gain of wealth, favour from the king, increase of vigour and good health, if Mars occupies the tenth.

There is gain of wealth from trade and from royal quarters, happiness from friends, strength and increase in beauty if Mercury is in the tenth in the year.

There is good renown, honour from kings, gain of wealth, happiness from friends, and constant celebrations at home, if Jupiter is in the tenth.

There is honour from the king, happiness from friends, gain of wealth and destruction of enemies, and all undertakings succeed for men, if Venus is in the tenth.

There is loss of wealth from business, danger arising from the king, paucity of happiness, and living abroad, if Saturn is in the tenth.

There is loss of land, constant danger, bodily suffering, loss of wealth, and enmity with loved ones and one's own people, if Rāhu occupies the tenth.

This concludes the judgement of the tenth house.

\subsection{The Eleventh House}

Next, the judgement of the eleventh house. Concerning that, Candeśvara describes what is to be considered from the eleventh house:

Accomplishment of undertakings; buying, increase and gain; elephants, horses, garments, seats, vehicles and beds; gain of knowledge and wealth, and gain of what was lost; efforts to win maidens and gold; [gain] of trees, sprouts and so on; ${ }^{162}$ the father-in-law and so on, and all gains are [considered] from the eleventh house.

Here, too, judgement is [to be made] as before. Now, configurations; [and] in the Jirnatäjika [it is said]:

162 Text witnesses G K T M read 'of hairs on the body and so on'. 
budhe varșeśvare saumyasaṃdrșțe dhanalābhage |

lābho vānijyatah saumye lagnage muthahāyute | likhanāt pațhanāl lābho varșe bhavati niścayāt || varșeśvare budhe șașțāșțāntyage krürasaṃyute | nīcakarmakrto lābhah svalpo jĩe pāpavīkșite |

budhe 'stage tādrśe ca na lābhah syāt kadācana \|

tejaḥsiṃhah |

lābhādhipe tanubhujā vihitetthaśāle

vīryānvite ca parivāradhanādivrddhih |

evam phalam tu muthahāpatinābdabhoktrā

sarve 'pi lābhagṛhagā dhanadāhn savīryāḥ \|

vāmanah |

varșeśvare lābhagate saumyagrahayutekșite |

likanāt pațhanāl lābhas tathaiva vyavahāratah \|

varșatantre |

saviryo jñah samuthaho lagne 'rthasahame śubhāḥ|

tadā nikhātadravyasya lābhah pāpadríá na tu \|

tājikabhūṣaṇe |

gaganabhavanasamsthā munthahā varșakāle

likhanapațhanaläbham sattvayuktā karoti |

nijapatisahitā sā randhraśatruryayasthā

vitarati bahuvighnam prāptikāle narāṇām \|

\footnotetext{
1 lābhage] bhāvage B N $\quad 2$ saumye] saumya K T M 3 likhanāt] lekhanāt G $\quad 5$ jñe pāpa] jñeyāpa B N 6 na] dhana B N 8 vihite-] vihīne- B N 10 -ābdabhoktrā] scripsi; -āṃgabhoktā B N G; -āngabhoktā K T M 16 samuthaho] samuthahā K T M 19 gagana] gaga B 21 vyayasthā] vyayasthitā B N; vyavasthā K T M 22 vitarati] vitaravi G
}

8-11 lābhādhipe ... savīryāḥ] DA 27.2 16-17 savīryo ... tu] VT 15.5 $19-22$ gagana ... narāṇām] TBh 4.83

10 -ābdabhoktrā] The emendation is supported by MS DA3. 
If Mercury as ruler of the year is aspected by benefics and occupies the second or eleventh house, there is gain from trade. If Mercury occupies the ascendant, joined to the munthaha $\bar{a}$, certainly there is gain from writing and reading in [that] year. If Mercury as ruler of the year occupies the sixth, eighth or twelfth house, joined to malefics, there is gain made by low work, [and only] a little, if Mercury is aspected by malefics. And if such a Mercury is [heliacally] set, there will never be any gain.

[And] Tejaḥsiṃha [says in Daivajñālaṃkrti 27.2]:

If the ruler of the eleventh house is endowed with strength and forms an itthaśäla with the ruler of the ascendant, there is increase of attendants, wealth and so on. The result is the same if [it forms an itthaśäla] with the ruler of the munthaha or with the ruler of the year. All [planets] occupying the eleventh house in strength give wealth.

[And] Vāmana [says]:

If the ruler of the year occupies the eleventh house, joined to or aspected by benefic planets, ${ }^{163}$ there is gain from writing and reading, and also from business.

[And] in Varșatantra [15.5 it is said]:

[If] a strong Mercury with the munthahā is in the ascendant, and benefics on the sahama of wealth, then there is gain of buried treasure, but not if a malefic aspects.

[And] in Täjikabhüṣaṇa [4.83, 5.10o it is said]:

Occupying the tenth house at the time of the year, the munthaha, joined to benefics, makes gain from writing and reading. Joined to its own ruler and occupying the eighth, sixth or twelfth house, it overcomes many hurdles at the time when they appear to men. ${ }^{164}$

163 Or: 'by the planet Mercury'. Reading, writing and trade are typically associated with Mercury; but as seen from the following quotation from Tãjikabhūṣaṇa 4.83, other sources use words that unambiguously mean 'benefics'.

164 Or: 'at the time of gain for men'. 
lābhe lābheśạ śubhair dṛ̦țayuktạ̣

svoccasthaś ced dūrasamsthaś ca sūryāt |

mātangāás̄āvāptim urvìvibhūṣā-

yoșāharșotkarșayuktam karoti\|

yādavaḥ |

janmāngape lagnapatītthaśāle muntheśvarenāpi sameśvarena |

dravyeśamukhyākhyayutau ca lābho janmābdayor lābhaśubhe 'bdake ca \| lagnage sahamape ca khalārte devamantrini dhanakșatir ugrā \|

janmavittabhuji varșatanūpe mūthaśilini nijocitalābhah \|

hillājah |

lagnaläbhapatì lābhe lagne vā lagnalābhapau |

lagne lābhādhipo vā syāl lābhe lagnādhipo bhavet \|

eko 'pi hi yadāyogas tadā lābhah suniścitam |

candrayoge viśeșena pūrno läbhah prakīrtitah \|

lābhe lagnādhipas tișthel lābhādhiśsna samyutah |

tadā läbhakarah śíghram candrayukto maharddhidạ̣ \|

läbhapo lagnapo lābhe lagnapas tatpuro 'thavā |

pañcame balavān saumyas tadā lābhah sadharmakah \|

lagnalābhapayor drștîi lābhe lābhakarì matā |

2 -sthaś ced] -sthakhed B 3 -āvāptim] -āvāsim G 7 lābho] scripsi; lābhe B N G K T M ॥ lābhaśubhe] lābham ubhe G || 'bdake ca] bdakena B N 8 ca] om. BN $\|$ mantriṇi] maṃnịitri N 12 lābhādhipo] lābhādigo K T M 14 yoge] yogi B 16 maharddhidaḥ] vivṛddhidaḥ K T M 19 dṛșțir] om. B N || karī] kārī sadā B N

1-4 lābhe ... karoti] TBh 5.100 $\quad 6-7$ janmānigape ... ca ca $^{2}$ TYS $12.114 \quad 8$ lagnage ... ugrā] TYS $12.112 \quad 9$ janma ... lābhạ̣] TYS 12.113 
If the ruler of the eleventh house is in the eleventh, aspected by or joined to benefics, occupying its exaltation ${ }^{165}$ while being far away from the sun, it makes gain of elephants and horses and endows [the native] with an excess of joy from land, ornaments and women.

[And] Yādava [says in Tājikayogasudhānidhi 12.114, 112, 113]:

If the ruler of the ascendant of the nativity has an itthaśāla with the ruler of the ascendant [of the year], or with the ruler of the munthah $\bar{a}$ or the ruler of the year, or if [it forms] the configuration called the foremost ${ }^{166}$ with the ruler of the second house, there is gain in [that] year, and [likewise] if there is a benefic in the eleventh house of the nativity and of the year.

If Jupiter as ruler of the sahama occupies the ascendant, afflicted by malefics, there is terrible loss of wealth.

If the ruler of the second house of the nativity has a mutthaśila with the ruler of the ascendant of the year, there is gain befitting one's own [station in life].

[And] Hillāja [says]:

Should the rulers of the ascendant and the eleventh house be in the eleventh, or the rulers of the ascendant and the eleventh house be in the ascendant, or should the ruler of the eleventh house be in the ascendant [while] the ruler of the ascendant is in the eleventh house when one [such] configuration [is present], then certainly there is gain. Particularly if the moon is configured [with these rulers], the gain is declared to be complete.

Should the ruler of the ascendant occupy the eleventh house, joined to the ruler of the eleventh house, then it swiftly causes gain; if joined to the moon, it gives great prosperity. [If] the ruler of the eleventh house [and] the ruler of the ascendant are in the eleventh, or else the ruler of the ascendant is ahead of it, [and] a strong benefic is in the fifth, then there is gain conforming to that [benefic]. The aspect of the rulers of the ascendant and eleventh house on the eleventh house are

165 Only Mercury in Virgo can be ruler of the eleventh house while occupying the same house in its exaltation.

166 That is, an itthaśāla or applying aspect. 
nișphalāḥ kathitā yogā yadi candro na paśyati \|

sarvagrahekșite läbhe lābho viṃśaviśopakah |

evaṃ sarveșu bhāveșu vācyam sarvagrahekșanāa $\|$

śaśilābhapalagneśā anyonyam yutavīkșitāḥ |

lagnāt trikonavittasthāh śĭghram lābhapradā matāh ||

tiryagyonau gate lagne tiryagyonigato 'thava $\mid$

lābheśah śubhaḍrștaś cet paśuläbhas tadā bhavet \|

vilagnasaptāștamagāh pañcamasthāh śubhā grahāḥ|

vā candralagnapau șașthe balināv ṛnaläbhadau \|

samarasiṃhah |

nrpater gauravalābho me syād iti lagnalābhapatyoś ca |

snehadrśá síghram syād ripudrștyā bahudinair eva \|

āyeśe kendrasthe śaśiyutadrște ca pūrnaphalam asti |

sthirarāśau paripürnam care 'lpam ardhạ̣ bhaven miśre \|

devagurau kendragate svoccādige ca nrpaśubhāśā |

pūrnaphalā krūragrahanipīdite síghranāśsah syāt \|

mitreṇa saha prìtir bhavitā lagneśvarāyapatyoś ca |

priyadrștyā muthaśilatah prîtir vānyonyagṛhayānāt \|

kendrasthitayor anayor maitrī kila pūrvajātaiva |

paṇapharagayoḥ puraḥsthā nāpoklimato matā prïtị $\|$

atha lābhabhāvasthitānāṃ sūryādīnāṃ phalāni padmakośe |

4 yutaviksṣitāḥ] yadi nirīkṣitāḥ B N $\quad 5$ trikoṇa] trikoyā N \| vittasthāḥ] vilasthāḥ G 6 gate] lābhe add. B N || gato] gate B 7 paśu] paśubhā $\mathrm{N}$ a.c.; paśubha $\mathrm{N}$ p.c. 11 lābho] lābhau B N 14 paripūrṇaṃ] parirṇam N \|| 'lpam ardhaṃ] lpārddhaṃ B N 15 gate] te add. T || svoccādige] scripsi; svoccādigate B N G K T M 16 nipị̣̄ite] pīḍite B N K T M \| śīghra] śāpra $G \quad 17-20$ mitreṇa ... prîtih] om. B N K T M 18 gṛha] scripsi; graha G 20 -gayoḥ] scripsi; -gatau G \|| puraḥsthā] scripsi; purasthā G

11-14 nrpater ... miśre] In place of these two stanzas, $G$ has the following four (the first three of which correspond closely to PT 2.123-125), similar in meaning: nrpater gauravalābhāśā mama syān na veti vā varșe āyeśalagnapatyoh snehadrśā muthaśile 'dbhutam bhavati ripudrștyā bahudivasaị keṃdre cāyeśacaṃdre kaṃbūle vācyā pūrnaivāśā carasthiradvisvabhāvake svanāmaphalā mande krūropahate bhūtyāśāsu praṇaśam upayāti krūrāc chuddhe śubhasamparke 'py adhikalabdhāśá | keṃdroccage ca pūrṇa pādonāśā svarāśige jīve | arddhā svahaddasamsthe svalpā keṃdrād vahisthe ca| 11 me] The word has been blotted in B, perhaps intentionally. 14 paripūrṇaṃ] A vertical line marks the omitted syllable in N. 
considered to cause gain; [but these] configurations are declared to be fruitless if the moon does not aspect.

If the eleventh house is aspected by all planets, there is gain of twenty vimśopaka [coins]. [Results] should be predicted thus from all the houses when aspected by all planets. The moon, the ruler of the eleventh house and the ruler of the ascendant, joined to or aspecting one another while occupying trines or the second house from the ascendant, are considered to give gains. If the ascendant occupies [a sign of] an animal species, or if the ruler of the eleventh house, occupying [a sign of] an animal species, is aspected by benefics, then there will be gain of cattle. Benefic planets occupying the ascendant, seventh [or] eighth, [or] placed in the fifth, or the moon and the ruler of the ascendant strong in the sixth, give gains from debts. ${ }^{167}$

[And] Samarasiṃha [says in the Tājikaśāstra]:

'Will I receive honour from the king?' [If a client asks thus], by a friendly aspect between the rulers of the ascendant and the eleventh house, it will happen quickly; by an inimical aspect, only after many days. If the ruler of the eleventh house occupies an angle, joined to or aspected by the moon, the result is full; in a fixed sign it will be complete, little in a movable one, and half in a mixed one. ${ }^{168}$ If Jupiter occupies an angle in its exaltation and so on, the results of the king's goodwill are complete, [but] if afflicted by malefic planets, it will come to a swift end.

From a mutthaśila by friendly aspect between the ruler of the ascendant and the ruler of the eleventh house, there will be affection between [the native and] his friend; or by [these planets] occupying each other's houses, [there will be] affection. If they occupy angles, the friendship already exists; if they occupy succedents, it is imminent; in cadents, no affection is considered [to arise].169

Next, the results of the sun and other [planets] occupying the eleventh house [are described] in [Tājika] padmakośa [1.11, 2.11, 3.11, 4.11, 5.11, 6.11, 7.11, 8.11]:

167 It is not clear whether the gain is meant to come from borrowing money or from lending it. Another possible meaning is 'debts and gains'.

168 In the place of the preceding verses, text witness $G$ gives verses of identical metre and similar in content, but differently phrased.

169 This paragraph is included only by text witness $\mathrm{G}$. 
ravir lābhago lābhakārī nrpā̄t syād

dhanāptiś ca dhānyāmbaram vai hiraṇyam |

vilāsādisaukhyam ripūnāạn vināśam

sutāngeșu pị̣̂a bhavet taddaśāyām \|

ripor nāsanaṃ lābhasaṃsthe śaśāinke

bahudravyaläbham kraye vikraye 'pi

nrpāt saukhyaläbhah sutasyāgamaś ca

pratișthāvivrddhir bhaved dhāyane 'smin ||

avanitanayaläbhe räjyaläbho 'rthaläbho

bhavati ripuvināśs mitrapakșāj jayaś ca |

hayabhavanahiranyam prāpyate cāmbarāṇi

tanayasukhavināso jāyate hāyane 'smin \|

lābhasthitah śaśisuto jayasampadaś ca

dhānyāmbarāṇi bahulāni karoty avaśyam |

kānter vivardhanam athārtivināśanam ca

syād dhāyane paśuvivardhanam atra lābhah $\|$

jayo mānavānām surejye ca lābhe bhaved gohayānāṃ gajānāṃ ca lābhah | sutasyodayo jāyate śatrunāśa ḥ pratișțāvivrrddhir nrpāc cāpi saukhyam \|

kavir lābhago lābhakṛt svarnadah syāj

jayam mānavānām karotīha varșe|

sutānām vivrrddhiṃ sukham rājapakșād

ripūṇām vināśam tathā mitravrddhim $\|$

lābhasthito bhāskarasūnur atra hiraṇyagobhūmirathāśvalābham |

arthāgamam kīrtivivardhanam ca saṃtānapị̀ām prakaroti varșe \|

läbhasthitaś cet khalu saiṃhikeyo naram narendreṇa samam karoti |

hiraṇyagobhūdhanasaṃcayam ca śatrukșayam putrabhayam tathaiva \|

maṇitthạ |

6 'pi] ca K T M $\quad 7$-āgamaś ca] -āgama syāt B 13 sampadaś] sampadāṃ B N G 17 lābhe] lābho G || gohayānāṃ] gotrajānāṃ G 18 vivṛddhir] vivṛddhiṃ $G \quad 19$ lābhago] lābhado $G$ 21 vivṛddhiṃ] vivṛddhiḥ G; vivṛddhis K T M 22 vināśam] vināśo M || vṛddhim] vṛddhiḥ K T M 24 ca saṃtāna] saṃcatāna N 25 naram] ] paraṃ B N

1-4 ravir ... daśāyām] TPK 1.11 $\quad 5^{-8}$ ripor ... 'smin] TPK 2.11 $\quad 9^{-12}$ avani ... 'smin] TPK 3.11 13-16 lābha ... lābhah] TPK 4.11 $\quad 17-18$ jayo ... saukhyam] TPK 5.11 $19-22$ kavir ... vṛddhim] TPK 6.11 $\quad 23-24$ lābha ... varșe] TPK 7.11 $\quad 25^{-26}$ lābhasthitaś ... tathaiva] TPK 8.11 
The sun occupying the eleventh house makes gain from the king; there will be gain of wealth, grains, garments and gold; there will be happiness from pleasures and so on, and destruction of enemies, [but] bodily suffering to [the native's] children in its period.

There will be destruction of enemies if the moon occupies the eleventh house, and much gain of goods through buying and selling; [the native] gains happiness from the king and gets a child, and his eminence increases in that year.

When Mars is in the eleventh house, there is gain of dominion, gain of wealth, destruction of enemies and triumph on account of friends; he obtains horses, houses, gold and garments, [but] his happiness from children is destroyed in that year.

Occupying the eleventh house, Mercury certainly makes triumphs and riches and abundant grains and garments. There will be increase in beauty, removal of pain, increase of cattle, and gain in that year.

There will be triumph for men if Jupiter is in the eleventh house; gain of cattle, horses and elephants; there is the birth of a child, destruction of enemies, increase in eminence, and happiness from the king.

Venus occupying the eleventh house will make gains and give gold; it makes triumphs for men in this year, increase of children, happiness on account of the king, destruction of enemies and increase of friends.

Occupying the eleventh house, Saturn brings about gain of gold, cattle, land, chariots and horses, acquisition of wealth and increase of renown, [but] suffering to offspring, in that year.

If Rāhu occupies the eleventh house, it makes a man equal to a king, amassing gold, cattle, land and wealth, and destroys enemies, [but] also makes danger to children.

[And] Manittha [says]: 
vājivrșāadidravyāptiḥ pramodaḥ sveștavargataḥ| nrpaprasādam ārogyam varșalābhagate ravau \| putravastrādikaprāptir dhanasyālayasambhavaḥ| śvetakrayānakāal lābho varșe lābhasthite vidhau \| jāyāputrasuhrtsaukhyam pratāpo vibhavāgamaḥ| śatrukșayam nrpāt saukhyam lābhage bhüminandane \| dravyaläbham tathārogyam prabhoḥ prïtivivardhanam | śubhakrayānakāal lābho lābhasthāne yadā budhaḥ \| āyur ārogyam aiśvaryam jāyāpatyasuhṛtsukham | nrṇām catușpadaprāptir devejyo lābhago yadi $\|$ jalamārgād dhanaprāptis tathā śubhakrayānakāāt | priyāgamas tathā saukhyam lābhage bhrgunandane \| dravyāgamaṃ tathaiśvaryam ārogyaṃ yoșitām sukham | śūdrāt svalpāsrito lābho varșe lābhagate śanau \| śarīrārogyam aiśvaryam strīsukham vibhavāgamaḥ| saṃkìrnavarṇato lābho rāhur lābhagato yadi ||

iti lābhabhāvavicāraḥ ||

atha vyayabhāvavicārah | tatra vyayabhāve kiṃ vicāraṇiyam ity uktạ̣ cạ̣deśvareṇa |

\footnotetext{
1 pramodaḥ] pramādeḥ B N 3 dhanasyā-] dhanasvā- G K T M $\quad$ 7-13 tathārogyaṃ ... dravyāgamaṃ] om. BN 11 krayāṇakāt] kṛpāṇakāt M 13 sukham] sukhyakaṃ N 14 śūdrāt] scripsi; pūrura B N; śūra G K T M 16 varṇato] varṇatī N 18 vicāraṇīyam] ciṃtanīyam G
} 
There is gain of horses, bulls and other property, rejoicing with kin and loved ones, the favour of the king and good health, if the sun occupies the eleventh house in the year.

[The native] gets children, garments and so on, begins to accumulate wealth, and there is gain from white articles, if the moon occupies the eleventh house in the year.

There is happiness from wife, children and friends, prowess, acquisition of fortune, destruction of enemies and happiness from the king, if Mars occupies the eleventh house.

There is gain of property and good health, increase in the affection of one's master, and gain from beautiful articles, when Mercury occupies the eleventh house in the year.

There is vitality, good health, rulership, happiness from wife, children and friends, and gain of quadrupeds to men, if Jupiter occupies the eleventh house.

There is gain of wealth from journeys by water, and likewise from beautiful articles, the arrival of a loved one, and also happiness, if Venus occupies the eleventh house.

There is acquisition of wealth and likewise rulership, good health, happiness from women, gain from menials and consisting of paltry [things], if Saturn occupies the eleventh house in the year.

There is a healthy body, rulership, happiness from women, acquisition of fortune and gain from [objects of] mixed colours, ${ }^{170}$ if Rāhu occupies the eleventh house.

This concludes the judgement of the eleventh house.

\subsection{The Twelfth House}

Next, the judgement of the twelfth house. Concerning that, Candeseśvara describes what is to be judged from the twelfth house:

170 Or 'from [people of] mixed estates'. 
tyāgādibhogādivivāhadānakrșyādikarmavyayasaṃśayaś ca|

pitrrvyamātrṣvasrmātulānīyuddham kșatir yuddhaparājayaś ca |

samprekșaṇam tac chvasurādivittam kulam tathaitat kathitam vyayākhye \|

atrāpi vicāraḥ pūrvavat | atha yogāḥ | jïrṇatājike |

lagnābdapau naștabalau vyayāștaripusamsthitau |

nrbhe bhrtyakșayo 'nyarkșe syāc catușpadanāśanam ||

varșeśvare site șașthasthite bhrtyakșayo nrbhe |

catușpade 'śvādināsó vibale krūravīkșite \|

daśamasthe sabhaumendau syāc catușpadanāśanam |

vyākulatvam ca bhaumādhye candre vyayagate tathā $\|$

șașthage 'bdapatau sūrye sapāpe paśum āśrite |

bhrtyaih samam kalir varșe vyayāștasthe 'pi tat phalam \|

mande 'bdape balayute ripurihphagate tath $\bar{a} \mid$

bhūvātikikāvrkșaropo jalāśrayakrtir bhavet \||

vāmanah |

vyayasthe varșape mande gurau vā śubhavīkșite |

pravāsanirmitām bhūmiprāptị̣ tatra vinirdiśet ||

yādavah |

bhaume catuspadayute daśame caturthe

mandāvalokitayute svahrtis tathārtih $\|$

șașthe site 'bdādhipatau caturthe krūreṇa drșțe ca yute rugārtiḥ|

1 kṛ̣yādi] kṛ̣ṇādi KM || karma] karmā K || saṃśayaś] saṃjñakaṃ G; saṃjñakañ K T M $\quad 2$ mātulānī] mātulānāṃ G K T M 3 tac chvasurādi] cet svasurādi G; cet śvasurādi K T; cec chvaśurādi M 6 nṛbhe] nụpe M $\|$ syāc] śvāc B N $\quad 7$ șașțha] șașțhe K T M $\quad 9$ sa-] ca B $\mathrm{N} 10$ bhaumāḍhye] bhaumasthe B N; bhaumābdau K M 12 -sthe 'pi] -sthorpa N || phalam] kalam K 14 bhūvāțikā] bhūvāsanaṃ G; bhūtāsanaṃ K T M \| vṛkșaropo] drumāropo G K T M || jalā-] bhūvāṭikābṛkșaropo jalā- add. N 17 pravāsa] āvāsa G K T M || prāptị̣] prāptaṃ B N 20 yute] yuteś G || svahṛtis] suhṛtis B N; ca hṛtis G 21 șașthe ... ārtiḥ] om. B N

19-20 bhaume ... ārtiḥ] TYS 12.117 
Renunciation and so on, enjoyment and so on, marriage, donations, work like ploughing, loss and doubt; paternal uncles, the mother's sisters and maternal uncles' wives; battles, injuries and defeat in battle; reflection, the wealth of the father-in-law and so on, and the family community: this is declared [to belong] to the twelfth house.

Here, too, judgement is [to be made] as before. Now, configurations; [and] in the Jìnatājika [it is said]:

[If] the rulers of the ascendant and the year have lost their strength and occupy the twelfth, eighth or sixth house in a human sign, there will be loss of servants; in another sign, loss of quadrupeds. If Venus as ruler of the year occupies the sixth, there is loss of servants in a human sign; in a quadruped [sign], loss of horses and so on, if [Venus] is weak and aspected by malefics. If the moon together with Mars occupies the tenth, there will be loss of quadrupeds, and likewise, there is agitation if the moon along with Mars occupies the twelfth house. If the sun as ruler of the year occupies the sixth with a malefic, placed in an animal [sign], there is quarrel with servants in [that] year. If it occupies the twelfth or eighth house, the result is the same. If Saturn as ruler of the year is endowed with strength and occupies the sixth or twelfth house, there will be planting of trees in a park [or] construction of a pond.

[And] Vāmana [says]:

If Saturn or Jupiter as ruler of the year occupies the twelfth house, aspected by benefics, one should predict the acquisition of land located abroad in that [year].

[And] Yādava [says in Tājikayogasudhānidhi 12.117]:

If Mars joins a quadruped [sign] in the tenth or the fourth, aspected by or joined to Saturn, there is loss of property and suffering.

If Venus is in the sixth as ruler of the year, [or] in the fourth, ${ }^{171}$ aspected by or joined to a malefic, there is suffering from illness. ${ }^{172}$

171 Or: 'If Venus is in the sixth and the ruler of the year in the fourth'.

172 This half-stanza is not attested in available independent witnesses of the Tãjikayogasudhānidhi. It may conceivably be a continuation of the preceding quotation (from Vāmana), though its metre differs from both. 
tājikasāre |

mandānvito rātripatir vyayastho devārcitaḥ șașțagato vilagnāt | tadārthanāśam prakaroti śĭghram bhūpād atho caurajanāc ca duștāt \|

atra viśeșam āha tejaḥsiṃhah |

bhāvā ime 'bdajanuṣor api vīryayogād

dadyuḥ phalaṃ svam abalāh phalahānidāḥ syuḥ|

kalpyaṃ dhanādiṣu vilagnam ataś ca kendra-

mukhyākhilāni bhavanāni matāni tajjñaiḥ \|

trailokyaprakāśe |

dvādaśe śobhanaḥ khețo vivāhādiṣu sadvyayam |

krūro 'py asadvyayam rājadasyubhyah kurute grahaḥ \|

vyaye sūrye nrpād daṇdaś candre kṣayaṇakādiṣu |

kuje krị̣̂āvinodādau budhe tu krayavikrayāt \|

jīve dharmavyayas tatra śukre veśyādikarmasu |

śanau vyaye vyayaḥ kraurye tv avinașțo yadā grahaḥ \|

varșatantre |

yatra bhāve śubhaphalo dușto vā janmani grahah | varșe tadbhāvagas tādṛk tatphalam yacchati dhruvam \|

tājikabhūṣaṇe |

prācām vicārānumatạ̣ nitāntam mayoditam dvādaśabhāvajātam | phalạ̣ balaṃ vīkṣya nabhaścarāṇām tad yojanīyaṃ hi daśāsu teșām || iti |

2 șașțhagato] divārcitah N $\quad 6$ abalāh phala] abalābala B N $\quad 7$ kalpyam] scripsi; kalpaṃ B N G; kalpan M K T \| dhanādiṣu] dhanādi B; dhadi N \| vilagnam ataś] vilagnamalaś G 8 matāni] yutāni B; yatāni N 11 asad] akṣād G \| grahạ̣] grahāḥ B N 12 kṣayaṇakādiṣu] ca kṣaṇakādiṣu B N; ca kașțataḥ K a.c.; ca kṣinne kașțataḥ K p.c.; kṣinne ca kașṭatạ̣ T M 15 avinașțo yadā] anișțonayadā B; avinașțovyadā N 20 prācām] prācyāṃ KT M || vicārānumataṃ] vicārāmanutạ̣ N $\quad 21$ iti] iti dvādaśabhāvavicāraḥ add. G

2-3 mandānvito ... dușțāt] TS $184 \quad 5^{-8}$ bhāvā ... tajjñaiḥ] DA $28.13 \quad$ 17-18 yatra ... dhruvam] VT 16.8 20-21 prācām ... teșām] TBh 4.88 
[And] in Täjikasāra [184 it is said]:

[If] the moon occupies the twelfth house together with Saturn, and Jupiter occupies the sixth from the ascendant, then it swiftly brings about loss of wealth through the king or through robbers and evil [men].

Concerning this, Tejaḥsiṃha states a special rule [in Daivajñālaṃkrti 28.13]:

These houses in the year and in the nativity will give their own results by a configuration of strength, [but if] weak, they will cause the loss of [those] results. Considering the second house and so on as the ascendant, experts reckon the angles and all other houses from that [house under consideration].

[And] in the Trailokyaprakāśa [it is said]:

A benefic planet in the twelfth makes good expenses on weddings and so on, but a malefic planet makes bad expenses through kings and robbers. If the sun is in the twelfth house, there is punishment from the king; if the moon, [spending on] harbours and so on; ${ }^{173}$ if Mars, on games and amusements; if Mercury, on buying and selling; if Jupiter, expenses from piety; if Venus, on activities with prostitutes and so on; if Saturn is in the twelfth house, there is expense from cruelty. [This is] when a planet is not corrupt.

[And] in Varșatantra [16.8 it is said]:

In whatever house there is a benefic or malefic planet in the nativity, a planet of the same kind occupying that house in the year definitely bestows its result.

[And] in Tājikabhūṣaṇa [4.88 it is said]:

I have described the results produced by the twelve houses entirely in accordance with the judgements of the ancients. Considering the strength of the planets, those [results] should be applied in their periods.

173 Text witnesses K T M read: 'if the waning moon, on evil things'. 
atha dvādaśabhāvasthitānāṃ sūryādīnāṃ grahānāṃ phalāni padmakośe |

vyayasthitaś cet khalu bhāskaro 'sau strìvigrahodvegakaro 'nghrirogakrt | vyayam ca śirșodaranetrapịdām karoti cintām ripubhir vivādam || śaśān்o vyayastho 'ritah pị̣̂anam syāt tathā sadryayam netrarogam karoti vivādam janānām mahākaștasādhyam kaphārtim ca gulmodayam tatra varșe $\|$ vyayaś cāpado bhümiputre vyayasthe bhaven netrapịdātha karne vikārah | śiro'rtir janānām virodhas tathā syāt kalatrāngapịdā bhaved atra varșe \| budhe dvādaśasthe ripūnām vivādo vyayo guptacintā ca karne vikāraḥ| daśā neștakārī bhaven netrapịdā kaphārtiś ca kaștam tathā hāyane 'smin ॥ rihphasthitah suragurur bahulavyathākrc chatrupravādanrpabhïtikaro hi varșe | netrānigapịdanakaphārtijanapravādam hānir bhayaṃ bhavati śophavikārakārī $\mid$ vyayagatabhrguje syāt sadvyayo vātapị̄̂a ripujanaparivādo netrayoś cāpi rogaḥ| bhavati nrpabhayam vai śokamohādikaștam jvaravamanavikāram mrtyutulyam bhayam ca \| vyayasthānage jāyate sūryaputre vyayo vikraye kleśacintā ca kaștam |

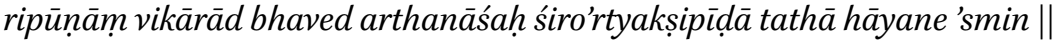
sthānabhramśo bhavati niyamān mānavānàm vyayasthe simhiputre ripubhayam atho bhrtyamrtyum vidhatte | śirsșe karṇe vyathanam udare netrarogaṃ narāṇām lakșmīhānih svajanakalahạ̣ kāminīnām prapịdā $\mid$

\footnotetext{
1 grahānāṃ] om. B N G 2 strī ... rogakṛt] strīvigraho 'bde 'ṃgakare 'ṃghrirogaṃ G 3 vivādam] vivādah $G$; vināśam $K$ T M 8 vyayaś] vyayaṃ $G \quad 9$ śiro'rtir] śirortim $B N$ 10 vyayo] vyaye B N 11 neșțakārī] neștakāro M \| kașțaṃ] om. G 15 śopha] śoka B N KM 18 nṛpa] ripu KT || mohādi] mohāni G 20 jāyate] hāyane KT 21 vikārād bhaved arthanāśah] vikārodbhave 'darthanāśạ G 22 bhavati niyamān] bhavatir bhanayamān G \| vyayasthe] vyayasthah G; vyayasthas K T M 23 putre] putro G K T M \| bhṛtya] martya B N; marttha G 24 udare] uvare G $\|$ rogam narāṇāṃ] rogāṅganānāṃ G

2-3 vyaya ... vivādam] TPK $1.12 \quad 4-7$ śaśāniko ... varșe] TPK $2.12 \quad 8-9$ vyayaś ... varșe] TPK $3.12 \quad 10-11$ budhe ... 'smin] TPK 4.12 $12-15$ rihpha ... kārī] TPK 5.12 $16-19$ vyaya ... ca] TPK 6.12 $\quad 20-21$ vyaya ... 'smin] TPK $7.12 \quad 22-25$ sthāna ... prapīịā] TPK 8.12
} 
Next, the results of the sun and other planets occupying the twelfth house [are described] in [Tājika] padmakośa [1.12, 2.12, 3.12, 4.12, 5.12, 6.12, 7.12, 8.12]:

If the sun occupies the twelfth house, it makes distress from discord with women and diseases of the feet; it makes loss, suffering from the head, stomach and eyes, anxiety, and quarrels with enemies.

[If] the moon occupies the twelfth house, there will be suffering from enemies, and it makes good expenses and illness of the eyes, quarrels with [common] people, [work that is] accomplished with great misery, suffering from phlegm and the appearance of abdominal tumours in that year.

There will be loss and misfortunes if Mars occupies the twelfth house, suffering from the eyes and ailments of the ears; there will be headache too, and enmity with [common] people; and there will be bodily suffering to [the native's] wife in that year.

If Mercury occupies the twelfth, there are quarrels with enemies, loss, secret anxiety and ailments of the ears: its period will bring no good, and there will be suffering of the eyes, afflictions of phlegm and evils in that year.

Occupying the twelfth house, Jupiter makes much agitation; it makes quarrels with enemies and danger from the king in [that] year. There is suffering of the eyes and limbs, afflictions of phlegm, quarrels with [common] people, loss and danger, and it makes ailments from tumours.

If Venus occupies the twelfth house, there will be good expenses, suffering from [the humour of] wind, quarrels with enemies and illness of the eyes; there is danger from the king, the evils of grief, confusion and so on, ailments of fever and vomiting, and danger equal to death.

If Saturn occupies the twelfth house, there is loss in selling, anxiety about suffering, and evils; there will be loss of wealth due to injury from enemies, and also headache and suffering of the eyes in that year.

Men certainly fall from their position if Rāhu occupies the twelfth house, and it gives danger from enemies and the death of servants; there is pain in the head, ears and stomach, and eye disease for men; loss of riches, quarrels with one's own people, and suffering to women. 
manitthah |

drșțirug dravyanāśaś ca vidveșo bandhuvargataḥ|

dehe pittodbhavā pīdā varșe sūrye vyayasthite \|

dravyakșayaṃ kșudhālpatvam netraruk kalaham gṛe |

varșakāle vyayasthāne candrah kuryād idam phalam \|

driśo rogam vapuhkaștam dhananāśam nrpād bhayam |

sutajāyādijam duḥkham hāyane dvādaśe kuje \|

svalpaläbham anārogyaṃ bahuvyayam nrpād bhayam |

svavarge kalaham nityam kuryāt saumyas tu rihphagaḥ $\|$

svajanair vigraham duhkham kṣayotpattir dhanavyayah |

pravāso nrpater bhïtir devejye vyayasamsthite \|

mitrasvajanavidveșah sanmārge vibhavavyayah |

nị̂sañgatvaṃ pravāsaṃ ca dvādaśe bhrguje nṛ̣ām ||

pādākșihrrdaye pị̂ām dravyanāśam nrpā̃d bhayam |

kalaham bandhuvargādau kuryān mando vyayasthitah $\|$

dhanavyayam ca kaștam ca rājapị̂ā ripukșayaḥ |

jāyāpị̣̂ā bhaven nityam svarbhānur dvādaśe yadi \|

grahāṇāṃ bhāvaphalaṃ svasvadaśāsu phaladam ity uktaṃ tājikabhūṣaṇe |

khecāriṇām bhāvaphalāni yāni

tānīha kalpyāni daśāsu teșām |

rāhos tu yad bhāvaphalam niruktam

śaner daśāyām khalu tat prakalpyam || iti |

viśeșam āha yādavaḥ |

3 pitto-] vitto- B N || vyayasthite] vyavasthite M 4 kalahaṃ] kalaho K T M 7 jāyādijaṃ] jīvādijaṃ B N K T M $\quad$ 7-10 hāyane ... duḥkhạ̣] om. B N 8 vyayaṃ] bhayạ̣ G 10 kṣayotpattir] kṣayotmati B N $\quad 11-12$ pravāso ... vyayah] om. B N $\quad 11$ bhītir] bhītiṃ G $\quad 16$ vyayaṃ] vyayaś $\mathrm{M} \quad 17$ yadi] atha add. K T $\left.\quad 18 \mathrm{sva}^{1}\right]$ om. G $\quad 21$ phalaṃ] phalā B N $\quad 22$ prakalpyam] kalpyam G

19-22 khecāriṇāṃ ... prakalpyam] TBh 5.99 
[And] Manittha [says]:

There is eye disease and loss os property, enmity with kinsmen, and bodily suffering caused by bile, if the sun occupies the twelfth house in the year.

Loss of property, poor appetite, eye disease and quarrels at home: [placed] in the twelfth house at the time of [the revolution of] the year, the moon makes these results.

There is illness of the eyes, bodily evils, loss of wealth, danger from the king, and suffering caused by children and wife, if Mars is in the twelfth in the year.

Mercury occupying the twelfth house will make little gains, poor health, many losses, danger from the king, and constant quarrels with one's own people.

There is discord with one's own people, suffering, developing consumption, loss of wealth, living abroad and danger from the king, if Jupiter occupies the twelfth house.

Men undergo enmity with friends and their own people, loss of fortune in a good cause, indifference and living abroad, if Venus is in the twelfth.

Occupying the twelfth house, Saturn will make suffering from the feet, eyes and heart, loss of wealth, danger from the king, and quarrels with one's kinsmen and so on.

There will be loss of wealth, evils, suffering from the king [but] destruction of enemies, and constant suffering to [the native's] wife, if Rāhu is in the twelfth.

It is said in Täjikabhūṣaṇa [5.99] that the results of the houses [occupied] by the planets give results in their respective periods: ${ }^{174}$

The results which the planets give [by occupying] the houses should be assigned to their periods; but the house results declared for Rāhu should be assigned to the period of Saturn.

Yādava states a special rule:

$174[$ T] he results $[\ldots]$ give results: the tautology is in the original. 
svoccasvaveśmāstaganīcaśatruhaddādivargasthitakhecarānām |

balābalatvādi vicārya samyak proktānusāreṇa vadet phalam tu \|

iti vyayabhāvavicāraḥ ||

iti śrīmaddaivajñavaryapaṇ̣itadāmodarātmajabalabhadraviracite hāyanaratne bhāvavicārādhyāyaḥ șașțhạ̣ $\|6\|$

2 samyak] sambhava $\mathrm{M} \| \mathrm{tu}$ ] tat $\mathrm{G} \quad 4-5$ iti ... șașțhah] om. B N 4 śrīmad] śrī K T M \| viracite] kṛte G 4 4-5 hāyanaratne] dvādaśa add. M 5 șașțhaḥ] om. G 
Fully considering the strength, weakness and so forth of the planets occupying their exaltations, domiciles, [heliacal] settings, falls, inimical [signs], haddā and other divisions, one should predict that result in accordance with what has been stated $\left[\right.$ here]. ${ }^{175}$

This concludes the judgement of the twelfth house.

In the Hayanaratna composed by Balabhadra, son of the illustrious learned Dāmodara, foremost of astrologers, this concludes the sixth chapter: the judgement of the houses.

175 I have not been able to locate this stanza in available independent witnesses of the Tājikayogasudhānidhi. 